THAIOMARA ALVES SILVA

\title{
AHNAK REGULA A FORMAÇÃO E TROCA DE VESÍCULAS EXTRACELULARES ENTRE CÉLULAS TUMORAIS DE MAMA \\ E FIBROBLASTOS
}

Tese apresentada ao programa de Pósgraduação em Biologia Celular e Tecidual, do Instituto de Ciências Biomédicas da Universidade de São Paulo, para a obtenção do Título de Doutor em Ciências. 


\section{THAIOMARA ALVES SILVA}

\section{AHNAK REGULA A FORMAÇÃO E TROCA DE VESÍCULAS EXTRACELULARES ENTRE CÉLULAS TUMORAIS DE MAMA E FIBROBLASTOS}

Tese apresentada ao programa de Pósgraduação em Biologia Celular e Tecidual, do Instituto de Ciências Biomédicas da Universidade de São Paulo, para a obtenção do Título de Doutor em Ciências.

Área de Concentração: Biologia Celular e Tecidual

Orientadora: Profa. Dra. Vanessa Morais Freitas

Versão original 
DADOS DE CATALOGAÇÃO NA PUBLICAÇÃO (CIP)

Serviço de Biblioteca e Informação Biomédica do

Instituto de Ciências Biomédicas da Universidade de São Paulo

reprodução não autorizada pelo autor

Silva, Thaiomara Alves.

AHNAK regula a formação e troca de vesículas extracelulares entre células tumorais de mama e fibroblastos / Thaiomara Alves Silva. -- São Paulo, 2015.

Orientador: Profa. Dra. Vanessa Morais Freitas.

Tese (Doutorado) - Universidade de São Paulo. Instituto de Ciências Biomédicas. Departamento de Biologia Celular e do Desenvolvimento. Área de concentração: Biologia Celular e Tecidual. Linha de pesquisa: Microambiente tumoral e câncer.

Versão do título para o inglês: AHNAK regulates formation and exchange of extracellular vesicles between breast tumor cells and fibroblasts.

1. Câncer de mama 2. Células estromais 3. Co-cultura 4. Vesículas extracelulares 5. AHNAK I. Freitas, Profa. Dra. Vanessa Morais II. Universidade de São Paulo. Instituto de Ciências Biomédicas.

Programa de Pós-Graduação em Biologia Celular e Tecidual III. Título. 
Candidato(a): $\quad$ Thaiomara Alves Silva.

Título da Tese: $\quad$ AHNAK regula a formação e troca de vesículas extracelulares entre células tumorais de mama e fibroblastos.

Orientador(a):

Profa. Dra. Vanessa Morais Freitas.

A Comissão Julgadora dos trabalhos de Defesa da Tese de Doutorado, em sessão pública realizada a .... considerou

\section{( ) Aprovado(a) \\ ( ) Reprovado(a)}

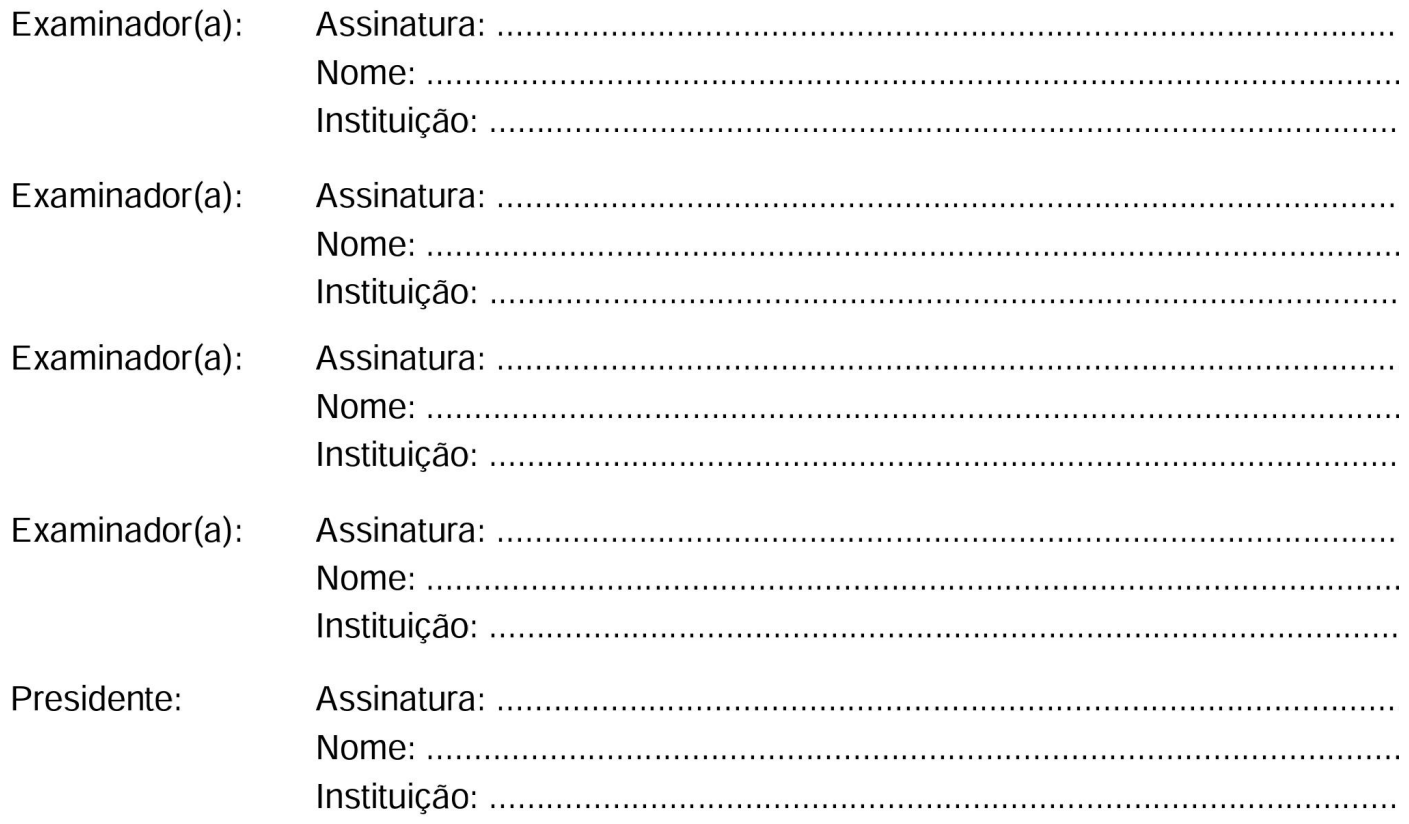


São Paulo, 03 de outubro de 2011.

\section{PARECER 1017/CEP}

A Comissão de Ética em Pesquisas com Seres Humanos do ICB, na sessão realizada no dia 21.09.2011, APROVOU o projeto intitulado: "O microambiente tumoral regulando neoplasias de mama e ovário. Papel das proteases ADAMTS" sob responsabilidade de execução dos autores Profa.Dra.VAnessa Morais Freitas e a aluna Thaiomara AlVES Silva.

Cabe os pesquisadores executantes elaborarem e apresentar a este Comitê, relatórios anuais ( parciais ou final), de acordo com a resolução 196/06 do Conselho Nacional da Saúde, item IX. 2 letra c.

$\mathrm{O}$ primeiro relatório deverá ser encaminhado à Secretaria deste CEP em 21.09.2012.

Atenciosamente,

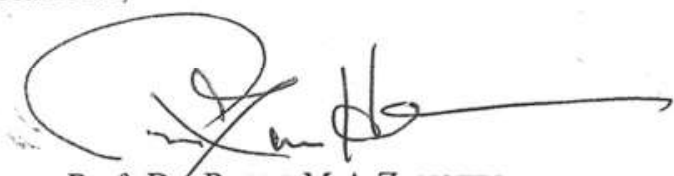

Prof. D. PaOlo M.A.ZanotTo

Coordenador da Comissão de Ética em Pesquisas com Seres Humanos - ICB/USP 
Dedico este trabalho a todas as pessoas e familiares que um dia passaram ou ainda passam por este obstáculo chamado câncer. 


\section{AGRADECIMENTOS ESPECIAS}

A Deus, pela minha vida e por cuidar dela. Pela alegria de mais uma conquista. O caminho percorrido pode ser cansativo e difícil, mas com Ele nada é impossível. Obrigada, Senhor!

Aos meus presentes de Deus, a minha família. Aos meus pais, Donizete A. Silva e Valdete F. Silva, pelo amor, paciência e confiança, por mais esta oportunidade proporcionada. A minha irmã Thaismara A. Silva, pelo apoio e carinho. Aos meus avós, Antônio Silva e Noraldina Alves, pelo incentivo e afeição. Pela torcida e apoio incondicional, ao longo de todo esse tempo. Vocês fazem parte desta conquista. Muito obrigada!

Ao meu namorado e amigo, Paulo Henrique P. Gonçalves, pelo amor e paciência, pelo incentivo e motivação a seguir rumo ao alcance de mais este objetivo. Você faz parte desta alegria. Obrigada! 


\section{AGRADECIMENTOS}

A Profa. Dra. Vanessa Morais Freitas, do Laboratório de Biologia da Matriz Extracelular, do Departamento de Biologia Celular e do Desenvolvimento, Instituto de Ciências Biomédicas da Universidade de São Paulo (ICB-USP), pela oportunidade de realização do curso de doutorado. Pela orientação e motivação no desenvolvimento e conclusão deste trabalho.

Ao Prof. Dr. Ruy Gastaldoni Jaeger, do Laboratório de Biologia Tumoral, ICB-USP, pela co-orientação, colaboração e auxílio, em todo decorrer desta pesquisa. E a toda sua equipe, em especial, Adriane S. Siqueira, Emerson S. Santos, Basílio Smuczek, Edilberto P. Oliveira, por toda disposição e ajuda oferecida.

Às professoras, Dra. Marilene Hohmuth Lopes (Laboratório de Neurobiologia e Células-tronco, ICB-USP), Dra. Nathalie Cella (Laboratório de Biologia Molecular da Célula Epitelial Mamária, ICB-USP) e a todo grupo de pesquisa. Pelo auxílio e disponibilização de espaço e equipamentos para a realização da parte experimental deste trabalho.

A Profa. Dra. Telma Maria Tenório Zorn, do Laboratório de Biologia da Reprodução e Matriz Extracelular, ICB-USP, e a toda sua equipe (Fernanda C. Barrence, Ambart E. Covarrubias, Juliane Sanches, Vivian Mazucato, Rafael Dalbosco, Mychel Raony P. Morais, Rodolfo F. Ribeiro) pelo ajuda e disponibilização da sala de cultura celular.

Às professoras, Dra. Maria Inês Borella, Dra. Claudimara F. Lotfi e Dra. Fernanda Ortis, pelas sugestões e críticas durante o Exame de Qualificação.

Ao Prof. Dr. André Zelanis (Instituto de Ciência e Tecnologia - UNIFESP) e a Profa. Dra. Solange M. T. Serrano (Laboratório Especial de Toxinologia Aplicada - Instituto Butantan) pelo auxílio com a análise proteômica.

A Profa. Dra. Vilma R. Martins e ao Dr. Marcos V. S. Dias (International Research. A. C. Camargo Cancer Center) pela ajuda com a análise por NanoSight. 
Às funcionárias da Secretaria do Programa de Pós-Graduação em Biologia Celular e Tecidual, ICB-USP, em especial, Regina C. Valbom, pelo auxílio durante o curso e pelo carinho e atenção prestada em todos os momentos.

Aos funcionários do ICB, em especial, Mário C. Cruz, pela aquisição das imagens no microscópio confocal (CEFAP-ICB); Edson R. Oliveira, Fernanda C. Barrence, Gaspar F. Lima e Gisela R. Terçarioli, pelo apoio e amizade, pela experiência na preparação de amostras e instrumentação na MET. E também, aos funcionários, Sebastião A. Boleta, Sonia Y. Almeida e Alfredo Duarte, pela assistência com a MEV; e Priscilla M. Lara, por toda ajuda proporcionada.

A todos meus amigos e pesquisadores do Departamento de Biologia Celular e do Desenvolvimento, ICB-USP. Em especial, Suély V. Silva, Maíra A. Lima, Rebeca P. Iglesia e Basílio Smuczek, pela amizade, apoio, consolo e pelas simples e boas gargalhadas, em todos estes anos.

Aos doutorandos, Basílio Smuczek pela colaboração com a técnica de Imunohistoquímica; e Iuri C. Valadão pelo auxílio com os ensaios de migração celular.

Aos meus amigos de fé, em especial, Ana Lucía Morocho, Ivaneide G. Santos, Sr. José Papa e Altiva Rodrigues, Diego P. Rodrigues, Giovana Fumes, Deolinda Antunes, Maria Tiemi Masuki e Beto M. Oliveira, que me deram bem mais que um ombro amigo, mas que neste período se tornaram uma família.

A Fundação de Amparo à Pesquisa do Estado de São Paulo (FAPESP), Agência de Fomento à Pesquisa Científica e Tecnológica do país, pelo auxílio financeiro necessário para a realização desta pesquisa e pela bolsa de doutorado concedida.

Muito obrigada! 
"Espera no Senhor Mesmo quando a vida pedir de ti mais do que podes dar E o cansaço já fizer teu passo vacilar Espera no Senhor

Mesmo se a solidão teu peito machucar E te der vontade de ir embora e tudo abandonar

Espera no Senhor Mesmo se o coração angustiado está Por ver alguém que amas longe do Senhor andar

Espera no Senhor Mesmo que suas promessas demorem a se cumprir E a vontade Dele seja sacrifício para ti Espera no senhor Há um Deus que te ama e Ele tudo pode transformar Seu amor te sustentará, espera n'Ele E Ele tudo fará, tudo fará" 


\section{RESUMO}

SILVA, T. A. AHNAK regula a formação e troca de vesículas extracelulares entre células tumorais de mama e fibroblastos. 2015. $115 \mathrm{f}$. Tese (Doutorado em Biologia Celular e Tecidual) - Instituto de Ciências Biomédicas, Universidade de São Paulo, São Paulo, 2015.

O câncer de mama é uma patologia genética, comum entre as mulheres, sendo o segundo tipo de câncer mais frequente no mundo. O sucesso no desenvolvimento de tumores não dependente apenas de mutações celulares, mas também é dirigido pelo microambiente tecidual onde ocorrem as interações entre as células tumorais e seu estroma circundante. A comunicação entre as células epiteliais e estromais é importante para a regulação da proliferação, do comportamento invasivo, dos processos angiogênicos e metastáticos de células cancerosas. A maioria das células liberam estruturas vesiculares para o espaço extracelular, no qual estariam envolvidas na sinalização celular e na progressão tumoral. As vesículas extracelulares são estruturas esféricas com bicamada proteolipídica e em seu interior existem diversas moléculas bioativas, metabólitos, lipídios, proteínas e material genético, que refletem a condição e o tipo celular de origem. O objetivo deste estudo foi analisar as interações mediadas por vesículas extracelulares entre as células tumorais e fibroblastos normais de mama, bem como, caracterizar as estruturas vesiculares derivadas de células tumorais de mama, determinando o número, tamanho, composição e supostas funções das proteínas destas vesículas; verificar o papel destas vesículas na proliferação celular. As células tumorais foram co-cultivadas com fibroblastos e cada uma das linhagens carregadas com diferentes corantes vitais. Nossos resultados evidenciaram a presença e a troca de vesículas entre as células tumorais e os fibroblastos de mama em co-cultura. Através das imagens obtidas por MET foi possível a visualização de protrusões das células cultivadas em monocultura, que possivelmente poderiam originar as vesículas, mostrando que as células tumorais apresentam mais protrusões do que os fibroblastos normais. Vesículas isoladas das células tumorais mostraram tamanhos e densidade heterogêneos. Células tumorais apresentaram maiores concentrações de vesículas que as células normais. A seguir, observamos o papel das vesículas extracelulares isoladas da linhagem celular tumoral MDA-MB-231 em algumas linhagens celulares e vimos que as vesículas induziram a proliferação celular de MCF-7, por meio da ativação da via de sinalização ERK 1/2. A análise proteômica mostrou que vesículas extracelulares derivadas de células tumorais de mama MDA-MB-231 são compostas pela proteína AHNAK, e esta, está distribuída no citoplasma (ao longo da membrana plasmática) e em vesículas das células tumorais de mama. Assim, decidimos silenciar a proteína AHNAK e verificar suas possíveis funções. Observamos que o silenciamento de AHNAK levou à redução da migração, invasão celular e a troca de vesículas, além da diminuição do número de protrusões celulares e da produção de vesículas. Com isso, estabelecemos um possível papel para AHNAK na produção e na troca de vesículas extracelulares. AHNAK é mais abundante em tumores de mama e nas metástases de linfonodo, do que no tecido mamário normal. AHNAK pode representar uma importante molécula do microambiente, presente em vesículas extracelulares, que influenciaria na biologia dos tumores de mama, atuando na comunicação célula-célula.

Palavras-chave: Câncer de mama. Células estromais. Co-cultura. Vesículas extracelulares. AHNAK. 


\begin{abstract}
SILVA, T. A. AHNAK regulates the formation and exchange of extracellular vesicles from breast tumor cells and fibroblasts. 2015. $115 \mathrm{p}$. Ph. D. Thesis (Cell and Tissue Biology) - Instituto de Ciências Biomédicas, Universidade de São Paulo, São Paulo, 2015.
\end{abstract}

Breast cancer is a genetic pathology, common among women and the second most frequent cancer in the world. The successful development of tumors is not only dependent on cell mutations, but is also driven by the tissue microenvironment, where there are interactions between tumor cells and their surrounding stroma. The communication between epithelial and stromal cells is important for regulation of cell proliferation, invasive behavior, angiogenic and metastatic processes in cancer. The majority of cells release vesicular structures into the extracellular space and could be involved in cellular signaling and tumor progression. The extracellular vesicles are spherical structures delimited by proteolipid bilayer, which contain a variety of bioactive molecules, metabolites, lipids, proteins and genetic material, reflecting the condition and the cell type of origin. The aim of this study was to analyze extracellular vesicle-mediated interactions between breast tumor cells and normal fibroblasts, and to characterize the vesicular structures derived from tumor breast cells, determining the amount, size, composition and function of the proteins within these alleged vesicles. Additionally, we determined the role of these vesicles in cell proliferation. Tumor cells (MDA-MB-231, MCF-7) were plated on top of fibroblasts monolayer and both cell lines were previous loaded with different vital dyes. Our results evidenced the presence and exchange of vesicles between breast tumor cells and fibroblasts in co-culture. By Transmission Electron Microscopy (TEM) it was possible to view the cell protrusions from monocultures, which can possibly originate vesicles. Tumor cells showed more protrusions compared to fibroblasts. Vesicles isolated from all the cell lines showed heterogeneous sizes. Both tumor cell lines secreted more vesicles than fibroblasts. Next, we examined the role of extracellular vesicles isolated from MDA-MB-231 in different cell lines. MDA-MB-231-derived vesicles induced MCF-7 cell proliferation through activation of ERK 1/2 signaling pathway. Proteomic analysis showed that extracellular vesicles derived from MDA-MB-231 presented AHNAK protein. AHNAK is distributed in the cytoplasm along the plasma membrane and was detected in MDAMB-231-derived vesicles. Next, we decided to silence the AHNAK protein and check its functions. We observed that AHNAK depletion promotes a decrease on cell migration, cell invasion and vesicles exchange. Also, the number of cell protrusions and vesicles secretion were reduced upon depletion of AHNAK. Therefore, we established a putative role for AHNAK in the release and exchange of vesicles. We then evaluated AHNAK expression in samples of human breast tissue both normal and tumoral by immunohistochemistry. AHNAK levels were more abundant in human tumor and in metastatic tissue when compared to the normal breast tissue. Our results support the hypothesis that AHNAK could represent a microenvironment-molecule with positive effects on breast tumor progression, mainly due to its role on cell-cell communication.

Keywords: Breast cancer. Stromal cells. Co-culture. Extracellular vesicles. AHNAK. 


\section{LISTA DE ILUSTRAÇÕES}

Figura 1 - Representação esquemática do microambiente tumoral..............................22

Figura 2 - Troca de vesículas entre as células..........................................................28

Figura 3 - Vesículas extracelulares derivadas de células tumorais podem modular o

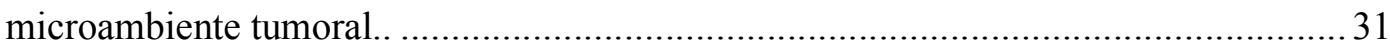

Figura 4 - Diversidade de vesículas liberadas pelas células................................... 33

Figura 5 - Representação esquemática das vesículas extracelulares............................ 34

Figura 6 - Tamanho dos principais tipos de vesículas extracelulares.......................... 36

Figura 7 - Vesícula extracelular e seus principais componentes.............................. 40

Figura 8 - Esquema da co-cultura com fibroblastos não tumorais e células tumorais de

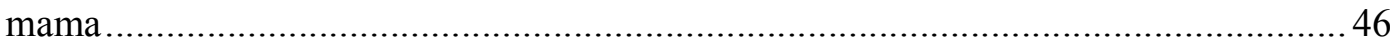

Figura 9 - Troca de vesículas entre as células tumorais de mama e fibroblastos não tumorais

Figura 10 - Células tumorais apresentam mais protrusões de membrana plasmática e vesículas extracelulares quando comparados com fibroblastos não tumorais.

Figura 11 - Análise do número de partículas mostra maior número de vesículas

liberadas pelas células tumorais MDA-MB-231 do que as células menos agressivas ou não tumorais. .66

Figura 12 - Efeito das vesículas isoladas das células MDA-MB-231 na proliferação e ativação da sinalização.

Figura 13 - AHNAK está localizada na membrana celular e em vesículas das células MDA-MB-231

Figura 14 - AHNAK está localizada em vesícula doada da célula MDA-MB-231 para

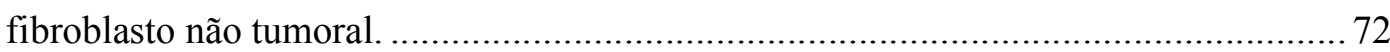

Figura 15 - Silenciamento de AHNAK inibe a formação e troca de microvesículas.... 74 Figura 16 - Diminuição da migração e invasão celular foi estimulada pela diminuição da expressão de AHNAK. .76

Figura 17 - O silenciamento da proteína AHNAK afetou o número de protrusões celulares e de vesículas das células MDA-MB-231. 78

Figura 18 - AHNAK é mais abundante no tecido tumoral e no carcinoma metastático, quando comparado com o tecido normal. 


\section{LISTA DE ABREVIATURAS E SIGLAS}

ACN acetonitrila

AEBSF do inglês "4-(2-Aminoethyl) benzenesulfonyl fluoride hydrochloride", traduzido como cloridrato de 4-(2-aminoetil) fluoreto benzenossulfonil

BCA do inglês "bicinchoninic acid", traduzido com ácido bicinconínico

BRCA do inglês "breast cancer", traduzido como gene do câncer de mama

BrdU 5-bromo-2'-desoxiuridina

BSA do inglês "Bovine serum albumin", traduzido como albumina sérica bovina

CCD do inglês "charge-coupled device", traduzido como dispositivo de carga aclopada

CD do inglês "Cluster of differentiation" ou "Cluster of designation" ou "Classification Determinant", traduzido como Conjunto de diferenciação ou Conjunto de designação ou Classificação determinante, utilizado para a identificação e investigação de moléculas da superfície celular.

CDI carcinoma ductal invasivo ou infiltrativo

CEFAP-ICB Centro de Facilidades para Pesquisa - Instituto de Ciências Biomédicas

CEPSH Comissão de Ética em Pesquisa Envolvendo Seres Humanos

DMEM do inglês “Dulbecco's Modified Eagle's Medium”, traduzido como meio de Eagle modificado por Dulbecco

DMEM-F12 do inglês "Dulbecco's Modified Eagle's Medium/Nutrient Mixture F-12”, traduzido como meio de Eagle modificado por Dulbecco/Misturado com nutriente F-12

DMSO dimetil sulfóxido

DNA do inglês "deoxyribonucleic acid”, traduzido como ácido desoxirribonucleico

DTT ditiotreitol

ECL do inglês "Enhanced chemiluminescence"

EDTA do inglês "Ethylenediamine-tetra acetic acid", traduzido como ácido etilenodiamino tetra acético

EGF do inglês "Epidermal growth fator", traduzido como fator de crescimento epidérmico 
EMS do inglês "Electron Microscopy Sciences", traduzido como Ciência da Microscopia Eletrônica

ERK do inglês "extracellular-signal-regulated kinase”, traduzido como quinase regulada por sinais extracelulares

HEPES do inglês "4-(2-hydroxyethyl)-1-piperazineethanesulfonic acid", traduzido como ácido 4-(2-hidroxietil)-1-piperazinoetanossulfônico

HER-2 do inglês "human epidermal growth factor receptor 2", traduzido como receptor tipo 2 do fator de crescimento epidérmico humano

HOAc ácido acético

HSP do inglês "heat shock protein", traduzido como proteína de choque térmico

IAA iodoacetamida

IHQ Imunohistoquímica

INCA/MS Instituto Nacional do Câncer/Ministério da Saúde

LAMP do inglês "Lysosome-associated membrane protein", traduzido como proteína de membrana associada ao lisossomo

LCIS do inglês "Lobular carcinoma in situ", traduzido como carcinoma lobular in situ

LC-MS/MS do inglês "Liquid chromatography-mass spectrometry", traduzido como cromatografia líquida acoplada à espectrometria de massas sequencial

MCF-10A linhagem celular epitelial não tumoral de mama humana proveniente de uma paciente com alterações fibrocística

MCF-7 linhagem celular epitelial tumoral de mama humana derivada de infusão pleural de adenocarcinoma

MDA-MB-231 linhagem celular epitelial tumoral de mama humana derivada de infusão pleural de adenocarcinoma

MEC matriz extracelular

MET Microscopia eletrônica de transmissão

MEV Microscopia eletrônica de varredura

MHC do inglês "major histocompatibility complex", traduzido como complexo principal de histocompatibilidade

miRNA micro RNA

mRNA RNA mensageiro 
MVE do inglês "Multivesicular endosome", traduzido como endossomo multivesicular

NTA do inglês "Nanoparticle Tracking Analysis", traduzido como Análise de Rastreamento de Nanopartículas

PBS do inglês "phosphate buffered saline", traduzido como tampão fosfatosalino

PFA paraformaldeído

$\mathrm{pH} \quad$ potencial hidrogeniônico ou potencial de hidrogênio

PKB do inglês "Protein kinase B", traduzido como proteína quinase B

RNA do inglês "ribonucleic acid", traduzido como ácido ribonucleico

rpm rotações por minuto

SDS do inglês "sodium dodecyl sulfate", traduzido como Dodecil sulfato de sódio

SFB Soro fetal bovino

siRNA do inglês "small interfering RNA"

TBS do inglês "Tris-buffered salin", traduzido como tampão tris-salino

TEMED do inglês “Tetramethylethylenediamine”, traduzido como

tetrametiletilenodiamina

TFA ácido trifluoroacético

TfR do inglês "transferrin receptor", traduzido como receptor de transferrina

TSG do inglês "Tumor susceptibility gene", traduzido como Gene de susceptibilidade tumoral 


\section{LISTA DE SÍMBOLOS}

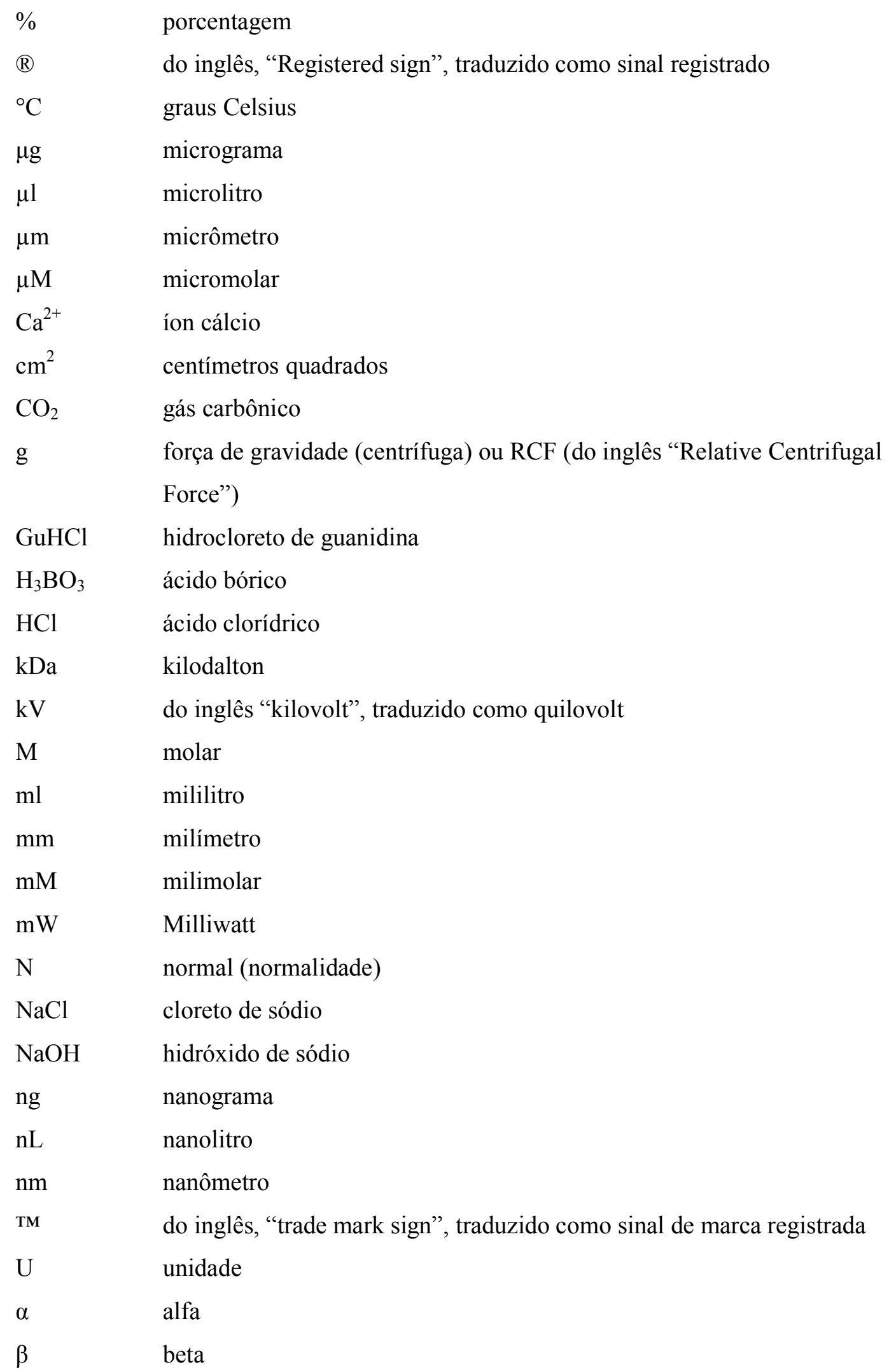




\section{SUMÁRIO}

1 INTRODUÇÃ

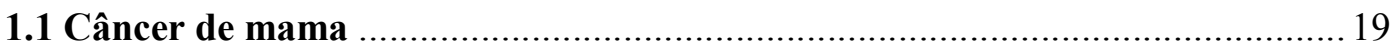

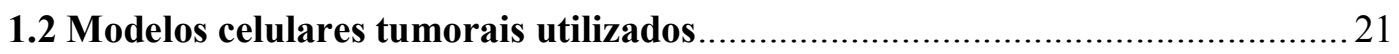

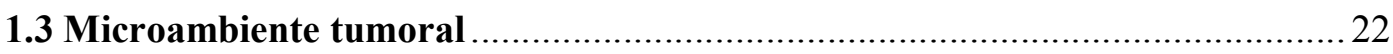

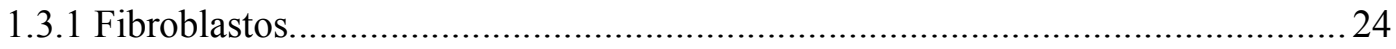

1.3.2 O comportamento celular pode ser observado por co-cultura ..........................25

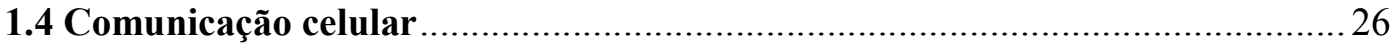

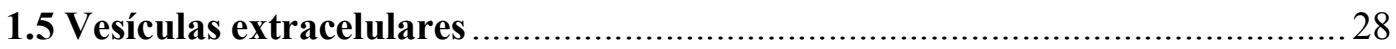

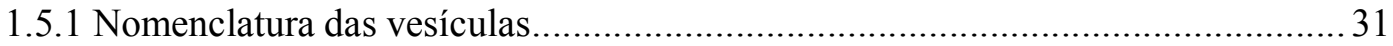

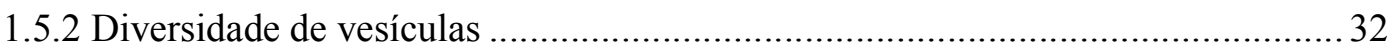

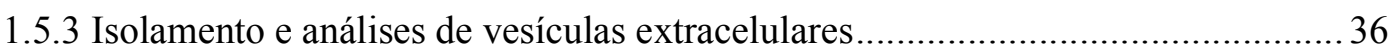

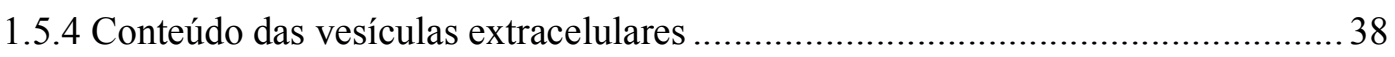

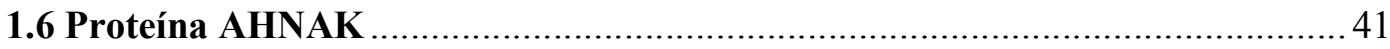

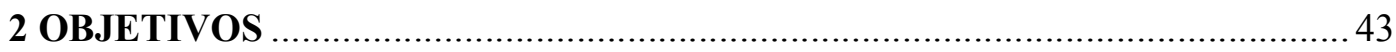

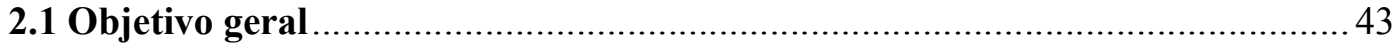

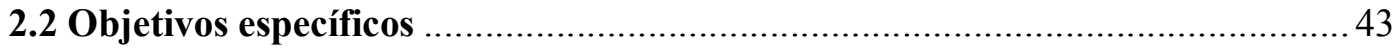

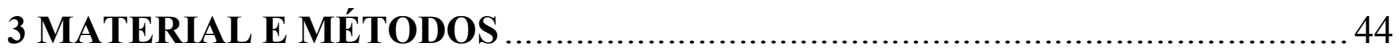

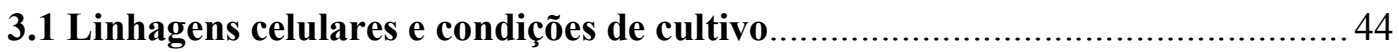

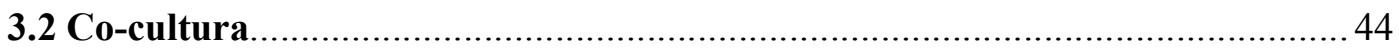

3.2.1 Quantificação de vesículas trocadas pelas células ............................................ 46

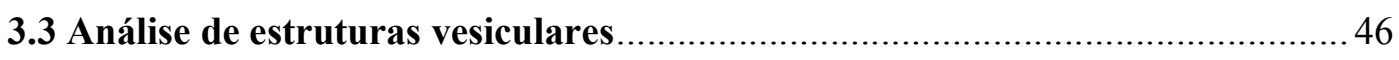

3.3.1 Isolamento das estruturas vesiculares das células tumorais de mama MDA-MB-

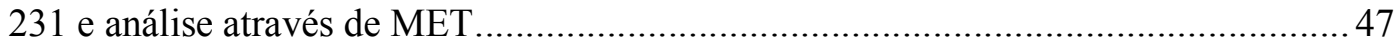

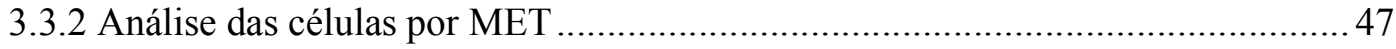

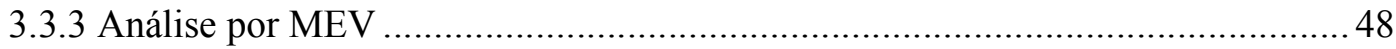

3.3.4 Análise e quantificação de vesículas extracelulares usando NanoSight .............. 49

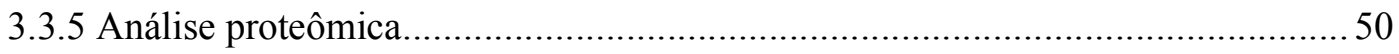

3.4 Efeitos da depleção de AHNAK em células tumorais ....................................52

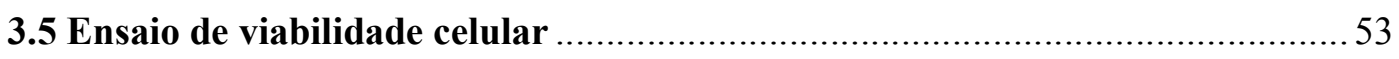

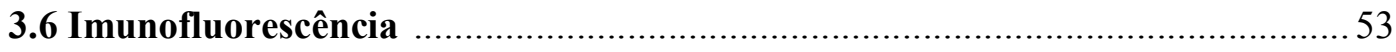

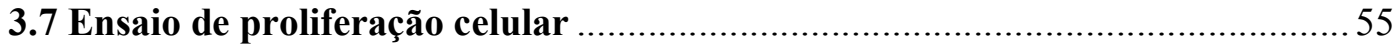

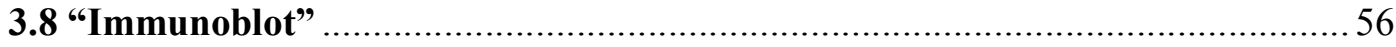


3.9 Ensaio de invasão e migração celular

3.10 Análise da expressão da proteína AHNAK através de imuno-histoquímica

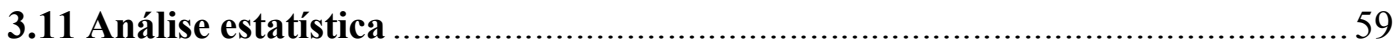

4 RESULTADOS

4.1 Troca de vesículas a partir de células tumorais de mama e fibroblastos não tumorais em co-cultura

4.2 Estruturas vesiculares e protrusões celulares em MET e MEV .

4.3 Análise e quantificação de estruturas vesiculares mostraram alta concentração de vesículas extracelulares das células tumorais de mama MDA-MB-231 .64

4.4 Análise proteômica de estruturas vesiculares liberado pelas células tumorais MDA-MB-231

4.5 As vesículas isoladas da linhagem celular MDA-MB-231 induzem a proliferação celular de MCF-7 por meio da ativação de ERK 1/2

4.6 Imunolocalização de AHNAK.

4.7 AHNAK está localizada na vesícula doada da célula tumoral MDA-MB-231 dentro do fibroblasto não tumoral

4.8 AHNAK silenciada levou à diminuição do número de microvesículas e diminuiu as vesículas doadas para os fibroblastos não tumorais 73

4.9 AHNAK silenciada promove a diminuição da migração e invasão celular....... 75

4.10 Efeito de AHNAK no número de protrusões celulares e vesículas..................77

4.11 Expressão de AHNAK é proeminente nos tumores da mama humano...........79

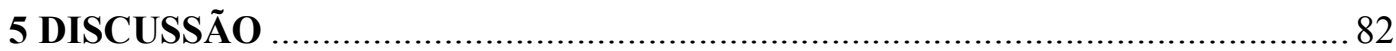

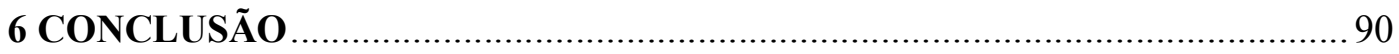

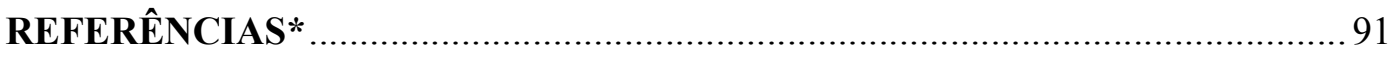

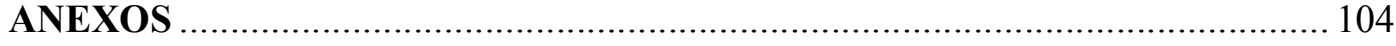

A - Tabela das proteínas identificadas na análise proteômica de vesículas derivadas de células tumorais de mama MDA-MB-231.. 


\section{INTRODUÇÃO}

\subsection{Câncer de mama}

O câncer de mama é uma patologia genética, comum entre as mulheres e causada pelo acúmulo de mutações, multiplicação anormal das células e assim, a geração da célula tumoral. O câncer de mama é o segundo tipo de câncer mais frequente no mundo, respondendo por $25 \%$ dos novos casos a cada ano e o tipo de câncer que mais causa mortes entre as mulheres. Sendo, a segunda causa de morte por câncer nos países desenvolvidos (atrás apenas do câncer de pulmão) e a maior causa de morte por câncer nos países em desenvolvimento (Instituto Nacional do Câncer/Ministério da Saúde INCA/MS, 2015). A incidência desta patologia altera-se entre as diferentes regiões do mundo, com as maiores taxas, em 2012, na Europa Ocidental (96 casos a cada 100 mil habitantes) e as menores taxas na África Central e na Ásia Oriental (27 casos a cada 100 mil habitantes). Nos últimos 40 anos, a sobrevida vem aumentando nos países desenvolvidos e, atualmente, é de $85 \%$ em 5 anos, enquanto que nos países em desenvolvimento, os valores permanecem entre 50\% e 60\% (INCA/MS, 2015).

Segundo o Instituto Nacional do Câncer (INCA), as taxas de mortalidade por câncer de mama no Brasil são elevadas, podendo estar relacionadas a diagnósticos tardios, onde a doença se encontra em estágio avançado. Assim sendo, o diagnóstico precoce aumenta a chance de cura do câncer de mama. Em 2015, esperam-se, para o Brasil, 576 mil novos casos de câncer, incluindo os casos de pele não melanoma. Destes, 57.120 casos são de câncer da mama, com um risco estimado de 56,09 casos a cada 100 mil mulheres. O desenvolvimento desta patologia está relacionado com alguns fatores de risco, como: envelhecimento (idade é um dos mais importantes fatores de risco, pois as taxas de incidência aumentam ligeiramente até os 50 anos, e após essa idade o aumento ocorre de forma mais lenta, o que reforça a participação dos hormônios femininos na etiologia do câncer de mama. Cerca de 4 em cada 5 casos ocorrem após os 50 anos de idade); histórico familiar (fator associado ao aumento no risco de cerca de 2 a 3 vezes para o desenvolvimento do câncer de mama; as mutações em alguns genes, por exemplo, os genes BRCA1 e BRCA2 (do inglês, "breast cancer"), aumentam o risco de desenvolver a doença, no entanto, cerca de 9 em cada 10 casos ocorrem em mulheres sem histórico familiar); fatores relacionados à vida reprodutiva da mulher; 
sedentarismo; excesso de peso; consumo de álcool; exposição à radiação ionizante; alta densidade do tecido mamário (razão entre o tecido glandular e o tecido adiposo). A amamentação, a alimentação saudável com a manutenção do peso corporal ideal e a prática de atividade física regular estão associadas a um menor risco de desenvolver o câncer de mama. Cerca de 30\% dos casos de câncer de mama podem ser evitados através destas simples medidas (INCA/MS, 2015).

No Brasil, estratégias como a mamografia (a cada 2 anos), para mulheres entre 50 a 69 anos de idade e o exame clínico das mamas anualmente, a partir dos 40 anos, são recomendadas para a detecção precoce do câncer de mama em mulheres com risco padrão. No entanto, estes mesmos exames são recomendados, anualmente, para mulheres mais jovens (a partir de 35 anos de idade), que fazem parte de grupos considerados de risco elevado para câncer de mama, como histórico familiar de câncer de mama em parentes de primeiro grau (INCA/MS, 2015).

Anatomicamente, as mamas femininas são compostas principalmente por lóbulos, que são unidades responsáveis pela produção de leite (MAHR; BHARGAVA; INSANA, 2012); ductos, que transportam o leite dos lóbulos para o mamilo; areóla; estroma, formado por tecido adiposo e tecido conjuntivo, que circunda os ductos e lóbulos; além de vasos sanguíneos e linfáticos (LESTER; COTRAN, 2000). As mamas femininas são órgãos que estão em constante remodelamento, pois sofrem alterações nos níveis hormonais durante cada ciclo menstrual (JOSHI; DI GRAPPA; KHOKHA, 2012).

Patologias da mama, em geral, surgem como massas palpáveis, lesões inflamatórias, secreção mamilar ou alterações anatômicas (LESTER; COTRAN, 2000). A maioria dos cânceres de mama (mais de 80\%) tem início nas células epiteliais que revestem os ductos (câncer ductal), porém alguns casos acometem células epiteliais que revestem os lóbulos (câncer lobular) e uma pequena porcentagem é proveniente de outros tecidos mamários (INCA/MS, 2015).

Existem alguns termos comuns quando o assunto é o câncer de mama, por exemplo: carcinoma, adenocarcinoma e sarcoma. O carcinoma é um tumor maligno desenvolvido a partir de células epiteliais que podem invadir os tecidos circundantes, originando as metástases (American Cancer Society, ACS, 2015). O tipo mais comum de câncer em humanos é o carcinoma, pelo qual ocorre um acúmulo de mutações somáticas em células epiteliais (BHOWMICK; NEILSON; MOSES, 2004). A maioria 
dos cânceres de mama são carcinomas, estes, podem ser ductal ou lobular. Os carcinomas, por sua vez, são divididos em carcinoma não infiltrante (não invasivo) ou in situ e carcinoma invasivo (infiltrante). O carcinoma ductal in situ de mama é uma forma muito inicial de neoplasia, no qual as células com características malignas não invadem a membrana basal, sendo incapazes de produzir metástases. No entanto, estas células podem disseminar através de ductos e produzir lesões extensas, comprometendo toda a área da mama. O carcinoma ductal invasivo (CDI) é o tipo de câncer de mama mais comum, tendo início nas células que revestem os ductos da mama. Estas células podem atravessar a parede dos ductos e invadir o tecido adiposo mamário; podendo ser capazes de disseminar para outras partes do corpo através do sistema linfático e da corrente sanguínea, ocorrendo as metástases. O carcinoma lobular in situ é uma condição na qual as células anormais são encontradas nos lóbulos da mama, estas, raramente levam a metástases. Enquanto que, o carcinoma lobular invasivo pode ocorrer metástases (ACS, 2015; LESTER; COTRAN, 2000). O adenocarcinoma é um tipo de carcinoma que ocorre a partir de células glandulares. Já o termo sarcoma é usado para designar cânceres raros, que desenvolvem a partir dos tecidos conjuntivo, muscular e adiposo, ou vasos sanguíneos (ACS, 2015).

\subsection{Modelos celulares tumorais utilizados}

As linhagens celulares tumorais de mama humana mais usadas como modelos experimentais em pesquisas sobre o câncer são: MDA-MB-231 e MCF-7. A linhagem tumoral MDA-MB-231 é proveniente do tecido mamário de uma paciente de 51 anos de idade com adenocarcinoma (tumor triplo negativo, que não apresentam receptores de estrógeno, progesterona e HER-2). Estas células são consideradas invasivas em modelos in vitro, porém de baixo índice metastático in vivo, embora, quando realizados ensaios pelo qual foram injetadas diretamente na circulação sanguínea, são adequadas para a observação de eventos de extravasamento celular (HARRIS et al., 2015; HOLLIDAY; SPEIRS, 2011).

Já a linhagem celular tumoral MCF-7, é considerada tumorigênica, porém não metastática (HARRIS et al., 2015). Estas células são provenientes do tecido mamário de uma paciente de 69 anos com adenocarcinoma. Em ensaios in vitro, apresentam características de um epitélio mamário normal, como a adesão célula-célula 
(HOLLIDAY; SPEIRS, 2011; MOHAMMADI, H. et al., 2013). Possuem a capacidade de processar o estrogênio, sob a forma de estradiol, através de receptores de estrogênio localizados no citoplasma da célula (MOHAMMADI H. et al., 2013) e por isso, esta linhagem tornou-se um modelo ideal para estudar a resposta hormonal (HOLLIDAY; SPEIRS, 2011).

Uma linhagem celular não tumoral também muito usada como comparativo em estudos sobre câncer de mama é MCF-10A. São células imortalizadas, não transformadas, provenientes de tecido mamário de uma paciente de 36 anos de idade com alterações fibrocísticas. Estas células possuem características de epitélio mamário normal, como: não tumorigenicidade, falta de crescimento independente de ancoragem e dependência de hormônios e fatores de crescimento para proliferação e sobrevivência. Apresentam discretas modificações genéticas típicas de células epiteliais mamárias adaptadas para cultura celular (DEBNATH; MUTHUSWAMY; BRUGGE, 2003; SOULE et al., 1990).

\subsection{Microambiente tumoral}

O sucesso no desenvolvimento dos tumores é conduzido pelo microambiente tumoral (BHOWMICK; NEILSON; MOSES, 2004; MURPHY, 2008). Esse microambiente é constituído por moléculas e componentes da matriz extracelular (MEC), bem como, por células normais (estromais) que cercam as células cancerosas. As células estromais circundantes podem ser: fibroblastos, células endoteliais, células do músculo liso, células do sistema imunológico e inflamatórias, entre outras. Essa elaborada infraestrutura responde ao processo de carcinogênese, protegendo o tumor do sistema imune, auxiliando o crescimento, promovendo a invasão e metástase tumoral (BURTON; LIBUTTI, 2009; QUAIL; JOYCE, 2013; SWARTZ et al., 2012).

Outros componentes presentes no microambiente tumoral são os vasos sanguíneos, através destes, os tumores recebem oxigênio e nutrientes, importantes para o desenvolvimento e crescimento tumoral. Deste modo, células tumorais podem sobreviver, induzir metástases e assim, atingir órgãos distantes (BHOWMICK; NEILSON; MOSES, 2004; HANNAFON; DING, 2013). A figura abaixo está ilustrando o microambiente tumoral. 


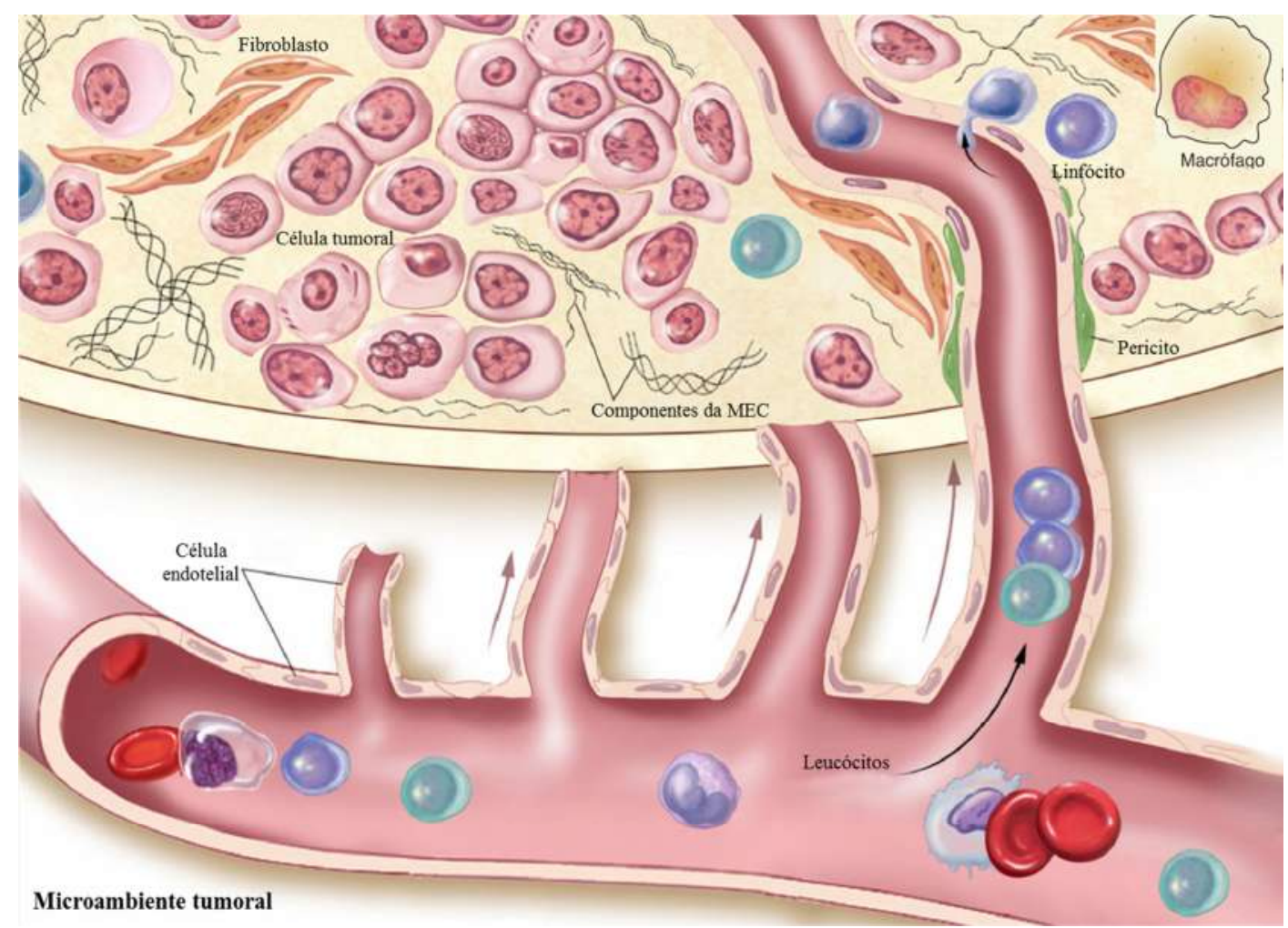

Figura 1 - Representação esquemática do microambiente tumoral. $O$ microambiente é constituído por moléculas e componentes da MEC, vasos sanguíneos e células estromais que cercam as células tumorais. As células estromais circundantes podem ser: fibroblastos, células endoteliais, células do sistema imunológico e inflamatórias, entre outras. Adaptado de (BURTON; LIBUTTI, 2009).

O microambiente tumoral responde à constante remodelação do tecido, nos quais ocorrem alterações metabólicas, expressão de fatores de crescimento que promovem o processo de angiogênese, alterações na MEC, mudanças no recrutamento de células estromais, incluindo uma variedade de células imunes e acelerada proliferação de fibroblastos (BHOWMICK; NEILSON; MOSES, 2004; HANAHAN; WEINBERG, 2011; KLEMM; JOYCE, 2015; SWARTZ et al., 2012). Por exemplo, a remodelação do tecido mamário que ocorre no pós-parto, durante a involução da glândula mamária, se torna um risco aumentado para o desenvolvimento do câncer de mama, porém a gestação proporciona efeito protetor do câncer para mulheres jovens (BORGES; SCHEDIN, 2012). Outra característica importante do microambiente tumoral é o conteúdo e a organização da MEC, cujas propriedades mecânicas podem afetar a 
diferenciação, bem como, a invasão celular. O aumento da rigidez do estroma mamário também é um fator de risco para o câncer de mama (SWARTZ et al., 2012).

Interações recíprocas entre os diversos tipos celulares do estroma e as células cancerosas regulam a progressão tumoral. Células mesenquimais não imunes, como fibroblastos, adipócitos e miofibroblastos, desempenham papel importante no microambiente tumoral, sendo estes, "direcionados" pelas células tumorais (SWARTZ et al., 2012). Desta maneira, o desenvolvimento do câncer não depende apenas do acúmulo de mutações genéticas nas células cancerosas, mas também da interação entre células tumorais e seu estroma circundante. A comunicação entre as células epiteliais e estromais é importante para a regulação da proliferação, do comportamento invasivo, dos processos angiogênicos e metastáticos de células cancerosas (HU; POLYAK, 2008).

\subsubsection{Fibroblastos}

A primeira descrição dos fibroblastos surgiu no final do século XIX, com base na localização celular e aspecto microscópico. Os fibroblastos apresentam aspecto alongado e fusiforme, são células mesenquimais, não epiteliais e não inflamatórias do tecido conjuntivo (sendo a principal célula deste tecido), são responsáveis pela síntese de vários constituintes da matriz fibrilar do tecido conjuntivo, como colágeno (tipos I, III e V) e fibronectina, bem como, proteases que degradam a MEC. Os fibroblastos são células estromais multifuncionais, que além da deposição, remodelação e homeostase da MEC, atuam na regulação da diferenciação e homeostase de células epiteliais associadas, na cicatrização de feridas (produzem MEC que serve como suporte para outras células), na regulação da inflamação e modulação da resposta imune (KALLURI; ZEISBERG, 2006; PARSONAGE et al., 2005; QUAIL; JOYCE, 2013).

Os principais marcadores para fibroblastos são vimentina, desmina, $\alpha$-actina de músculo liso, porém estes marcadores não são específicos apenas para esta linhagem celular. Vários marcadores podem ser considerados como indicadores específicos e locais de fibroblastos, por exemplo, a desmina que é específica para fibroblastos da pele (KALLURI; ZEISBERG, 2006). Os fibroblastos de mamíferos são muito heterogêneos, sendo que estas células isoladas a partir de diferentes locais, podem apresentar diferentes características e propriedades funcionais, como nos padrões de expressão 
gênica, produção e degradação de $\mathrm{MEC}$, além da capacidade de contractilidade e migração (PARSONAGE et al., 2005).

Os fibroblastos estromais podem influenciar o desenvolvimento do câncer, em resposta aos sinais das células tumorais. Durante o processo de tumorigênese, células pré-cancerosas adquirem várias mutações genéticas e os fibroblastos estromais adjacentes tornam-se "ativados", atuando de forma autócrina e parácrina, e desta maneira, auxiliam na sobrevivência tumoral (BHOWMICK; NEILSON; MOSES, 2004). Fibroblastos podem ainda contribuir com o processo de angiogênese (através da secreção de fatores de crescimento pró-angiogênicos) (KALLURI; ZEISBERG, 2006; YOON; KIM; GHO, 2014).

\subsubsection{O comportamento celular pode ser observado por co-cultura}

Vários estudos sobre o comportamento celular (avaliando proliferação, invasão e migração celular) já foram realizados através de ensaios de co-cultura entre fibroblastos não tumorais de mama ou fibroblastos associados ao câncer e células tumorais ou não de mama. No entanto, apresentaram resultados contraditórios, devido ao modo pelo qual foi realizado o ensaio, seja ele onde as células eram co-cultivadas diretamente (SHEKHAR et al., 2001) ou quando as células eram separadas por membrana microporosa, havendo interação através de fatores solúveis (CAMP et al., 2011; DONG-LE BOURHIS et al., 1997; STUELTEN et al., 2010; TYAN et al., 2012).

O perfil de expressão gênica também já foi estudado utilizando ensaios de cocultura. Santos e colaboradores (2011) realizaram ensaios de co-cultura usando membrana porosa, entre fibroblastos advindos de linfonodos axilares comprometidos ou não de paciente com câncer de mama e células epiteliais mamárias tumorais MDA-MB231, MDA-MB-435 e MCF-7. Neste estudo, os efeitos dos fibroblastos foram distintos, conforme as linhagens tumorais co-cultivadas (SANTOS et al., 2011). As alterações fenotípicas e da expressão gênica observadas através da interação de células tumorais e fibroblastos, sugerem que o contato célula-célula no microambiente é uma característica fundamental para cada tipo de câncer de mama (CAMP et al., 2011). Contudo, apesar de que nos ensaios de co-cultura in vitro não estarem presentes todas as células e fatores ambientais necessários para conferir uma situação real da célula no microambiente tumoral, a co-cultura tornou-se um método bastante utilizado para estudar o 
comportamento e a interação celular in vitro. Em geral, estes estudos tentam mimetizar eventos que ocorrem no microambiente tumoral in vivo.

Com relação à comunicação entre linhagens celulares tumorais e normais mediada por microvesículas, a interação por meio da troca de exossomos foram observados entre células tumorais de mama co-cultivadas com células-tronco derivadas de tecido adiposo humano (KUHBIER et al., 2014). Assim como o estudo entre células tumorais de mama metastáticas ou não e a troca de vesículas extracelulares entre estas células, bem como do seu conteúdo, na promoção de metástases (LE et al., 2014). Após co-cultura indireta, macrófagos associados ao câncer transferiram exossomos (e seu conteúdo, contendo miRNAs) para células tumorais de mama, promovendo a invasão celular (YANG et al., 2011).

\subsection{Comunicação celular}

A comunicação intercelular é uma característica essencial dos organismos multicelulares, sendo fundamental para a sobrevivência e manutenção da homeostase. Este processo pode ser mediado através do contato direto célula-célula (através de moléculas de adesão, junções comunicantes e nanotubos) ou pela transferência de moléculas secretadas, como fatores de crescimento, citocinas e hormônios (CHOI et al., 2015; EL ANDALOUSSI et al., 2013; RAPOSO; STOORVOGEL, 2013; VADER; BREAKEFIELD; WOOD, 2014). Com isso, as células interagem entre si, sincronizando a atividade metabólica, a expressão gênica e outros processos celulares (DE MAIO, 2011).

Outro mecanismo recém-descoberto é a comunicação intercelular que envolve a transferência de vesículas extracelulares (OHNO; ISHIKAWA; KURODA, 2013; RAPOSO; STOORVOGEL, 2013; YOON; KIM; GHO, 2014). As vesículas extracelulares estão relacionadas com a comunicação entre as células tumorais e as várias células do estroma, e assim, também interagem com o microambiente tumoral (ARAKELYAN et al., 2014; MARTINS; DIAS; HAINAUT, 2013; YUANA; STURK; NIEUWLAND, 2013); podendo colaborar com a progressão tumoral, processo angiogênico e imunológico, degradação da MEC e metástases (KUCHARZEWSKA; BELTING, 2013). A interação celular através de vesículas extracelulares serve como um mecanismo de tráfico intercelular de complexas mensagens biológicas, como a troca 
de moléculas que não pode ser realizada através de vias secretoras clássicas, ou que são predispostas a degradação extracelular (D'ASTI et al., 2012). Recentemente, estas vesículas extracelulares que participam da comunicação intercelular receberam o nome de comunicossomos intercelulares (CHOI et al., 2015).

A comunicação celular através de vesículas extracelulares é importante, pois as vesículas possuem grande número de moléculas em volume pequeno, no qual quando adentram na célula-alvo podem ativar várias vias de sinalização, simultaneamente. Outra vantagem é que essas vesículas podem percorrer longas distâncias, sem alterarem suas estruturas ou liberarem seu conteúdo, até interagirem com a célula-alvo (DE MAIO, 2011). Esta interação pode ocorrer através do processo de endocitose ou fusão com a membrana celular (D'ASTI et al., 2012; DE MAIO, 2011; RAPOSO; STOORVOGEL, 2013; ROBBINS; MORELLI, 2014).

Vesículas extracelulares não interagem com qualquer tipo celular, mas sim com determinadas células-alvo (COCUCCI; MELDOLESI, 2015). Esta interação ocorre devido a presença de ligantes específicos, presentes na superfície da célula ou da vesícula (COLOMBO; RAPOSO; THÉRY, 2014). A eficiência e as consequências desta interação podem depender da natureza das células envolvidas e do microambiente circundante (hipóxia, acidez, inflamação), nos quais podem controlar a liberação, o conteúdo e a entrada das vesículas extracelulares (D'ASTI et al., 2012). Na figura abaixo, pode ser observada a troca de vesículas entre as células. 


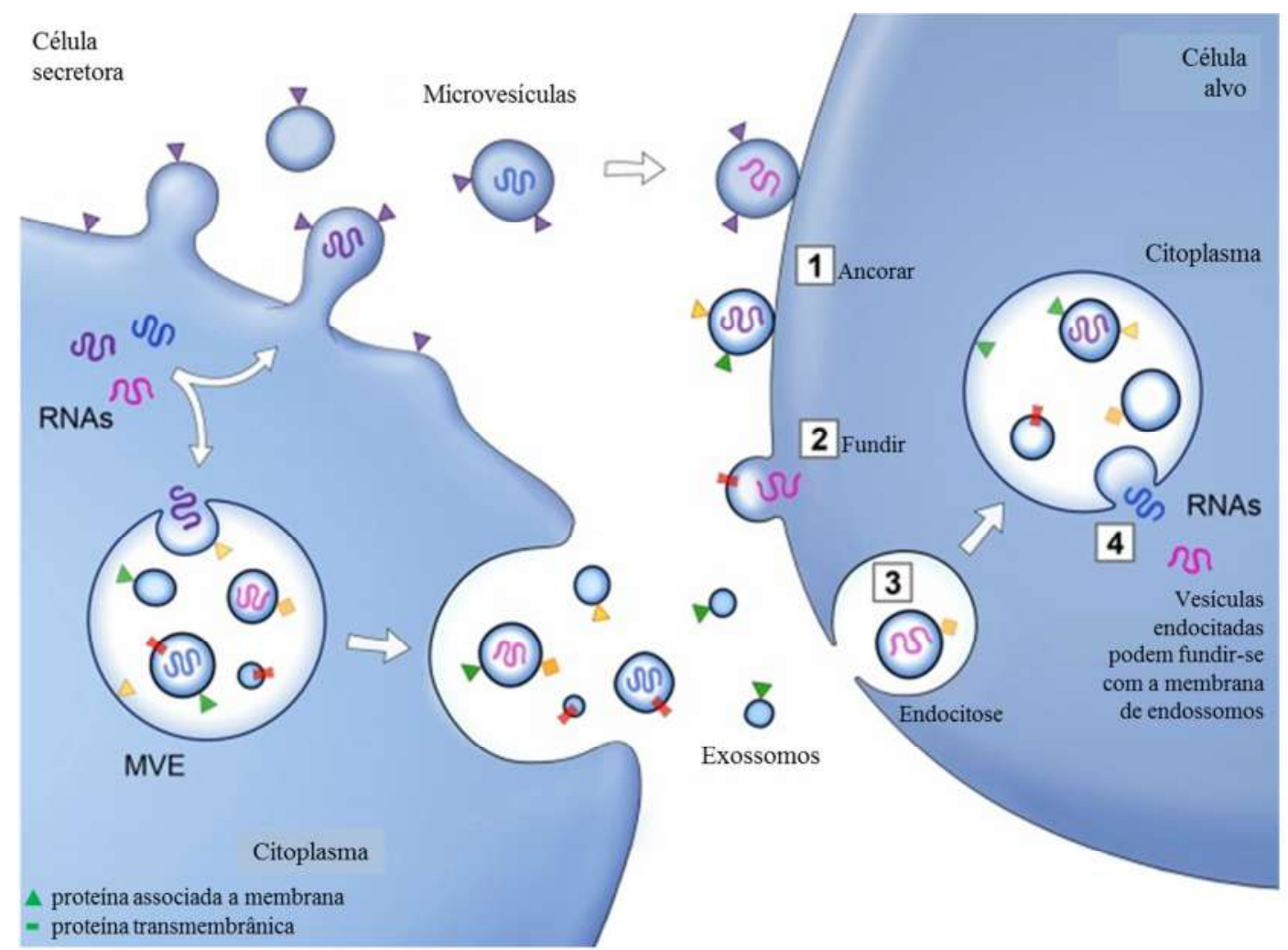

Figura 2 - Troca de vesículas entre as células. Neste processo ocorre a transferência de proteínas e RNAs através das vesículas. Proteínas associadas à membrana (triângulos), proteínas transmembrânicas (retângulos) e RNAs (símbolos de curvas) são incorporadas seletivamente a endossomos multivesiculares (MVE) ou em microvesículas que surgem a partir do brotamento direto da membrana plasmática. MVE fundem-se com a membrana plasmática para liberar exossomos para o meio extracelular. 1: Microvesículas e exossomos (vesículas extracelulares) podem ancorar na membrana plasmática da célula-alvo; 2: Vesículas podem fundir se diretamente com a membrana plasmática; 3: Vesículas podem ser endocitadas pela célula-alvo; 4: Vesículas endocitadas podem fundir-se com a membrana de endossomos. Adaptado de (RAPOSO; STOORVOGEL, 2013).

\subsection{Vesículas extracelulares}

A liberação de vesículas para o meio extracelular pode ser uma resposta adaptativa celular universal. As vesículas podem ser liberadas de diferentes tipos de células (in vivo e in vitro) em condições fisiológicas e patológicas (GYÖRGY et al., 2011), bem como, liberadas em resposta ao estresse celular (DE MAIO, 2011). Vesículas extracelulares podem ativar receptores, além de transferir informações biológicas entre as células (COCUCCI; MELDOLESI, 2015). As vesículas tornam-se importantes na fisiologia normal, porém podem levar a alterações em várias patologias (ARAKELYAN et al., 2014). 
A maioria das células liberaram continuamente vesículas e fatores solúveis para o meio extracelular. Por exemplo, os linfócitos T e mastócitos, que liberam o conteúdo dos seus grânulos de secreção (THÉRY; ZITVOGEL; AMIGORENA, 2002), além de adipócitos, neurônios, plaquetas, células dendríticas, epiteliais e endoteliais, dentre outras (HANNAFON; DING, 2013). Desta maneira, as vesículas também podem ser encontradas em muitos fluidos biológicos (amniótico, lacrimal, seminal, cefalorraquidiano, bílis), bem como, no plasma sanguíneo, saliva, leite materno e na urina (COLOMBO; RAPOSO; THÉRY, 2014; KIM, D. K. et al., 2015; MURALIDHARAN-CHARI et al., 2010; ROBBINS; MORELLI, 2014; SANDVIG; LLORENTE, 2012). Células não tumorais liberam vesículas para o meio extracelular, em quantidades menores. Vesículas de células endoteliais, por exemplo, são formadas após estimulação com citocinas e espécies reativas de oxigênio, e estas, podem estar elevadas no plasma sanguíneo de pacientes com doenças vasculares (GYÖRGY et al., 2011). Outro exemplo são as células do sistema nervoso, que liberam vesículas que atuam nos processos neurobiológicos, modulando várias funções (YOON; KIM; GHO, 2014).

As vesículas extracelulares são estruturas esféricas limitadas por bicamada lipídica, semelhante à membrana celular. Em seu interior existem diversas moléculas bioativas, lipídios, proteínas, DNA, mRNAs, miRNAs ou microRNAs e metabólitos que refletem a condição e o tipo celular de origem (KIM, D. K. et al., 2015; YOON; KIM; GHO, 2014).

Diferentes tipos celulares podem, por sua vez, liberar diferentes tipos de vesículas para o ambiente extracelular, simultaneamente, constitutivamente ou de forma regulada (CHOI et al., 2015; GYÖRGY et al., 2011; KIM, D. K. et al., 2015). Elas podem ser isoladas de fluidos extracelulares, ou seja, a partir do meio de cultura da célula (LÖTVALL et al., 2014). A classificação das vesículas pode ser quanto a sua origem e quanto as suas características (tamanho, densidade, morfologia, composição proteica e lipídica, dentre outras) (COLOMBO; RAPOSO; THÉRY, 2014; VAN DER POL et al., 2012).

As vesículas extracelulares desempenham papéis em vários aspectos da biologia, como: tráfego e comunicação intercelular; função no sistema imune, microbiologia, neurobiologia e no desenvolvimento; contribuem para diversas doenças (cardiovasculares, neurodegenerativas, câncer, infecções virais, como a AIDS); 
colaboram na biotecnologia (GOULD; RAPOSO, 2013; YOON; KIM; GHO, 2014); servindo como fonte de biomarcadores para diagnóstico e prognóstico de diversas patologias; além da terapêutica (ARAKELYAN et al., 2014; D'SOUZA-SCHOREY; DI VIZIO, 2014; KIM, D. K. et al., 2015).

Marcadores moleculares para diferentes patologias podem ser observados no plasma a partir de sangue total, com isso pode-se acompanhar a eficácia de um tratamento em diferentes pontos. O DNA circulante e miRNAs são estáveis em plasma, além do mais, estes marcadores podem ser encontrados no conteúdo de vesículas extracelulares presentes no plasma sanguíneo (BEST et al., 2015). Devido a esta estabilidade, vesículas extracelulares presentes em muitos fluídos corporais podem ser utilizadas como biomarcadores do câncer (MARTINS; DIAS; HAINAUT, 2013).

Células tumorais também liberam vesículas extracelulares para o microambiente tumoral (GYÖRGY et al., 2011), no qual podem controlar as células adjacentes (D'SOUZA-SCHOREY; CLANCY, 2012; MURALIDHARAN-CHARI et al., 2010; SANDVIG; LLORENTE, 2012). O processo de formação de vesículas na célula tumoral pode levar a várias alterações celulares, como: nos processos biológicos; aumento quantitativo da liberação de vesículas; mudanças na estrutura, tamanho e composição molecular (D'ASTI et al., 2012). Vesículas derivadas de células tumorais podem contribuir para a propagação do fenótipo transformado; colaborar com a capacidade de células tumorais resistirem ao processo imune; estimular a angiogênese, dentre outros (D'ASTI et al., 2012; D'SOUZA-SCHOREY; CLANCY, 2012; VADER; BREAKEFIELD; WOOD, 2014). Diversos estudos acreditam que estas vesículas também podem estar relacionadas com a progressão, invasão e metástase tumoral (D'ASTI et al., 2012; D'SOUZA-SCHOREY; CLANCY, 2012; HENDRIX; HUME, 2011; KUCHARZEWSKA; BELTING, 2013; VAN DOORMAAL et al., 2009). As microvesículas também podem servir como biomarcadores do câncer (D'SOUZASCHOREY; CLANCY, 2012; SANDVIG; LLORENTE, 2012). Contudo, todas estas informações sobre o papel das vesículas extracelulares advindas de células tumorais ainda são contraditórias, sendo necessários mais estudos que confirmem estes dados (COLOMBO; RAPOSO; THÉRY, 2014). A figura abaixo, esta representando possíveis papéis das vesículas extracelulares no microambiente tumoral. 


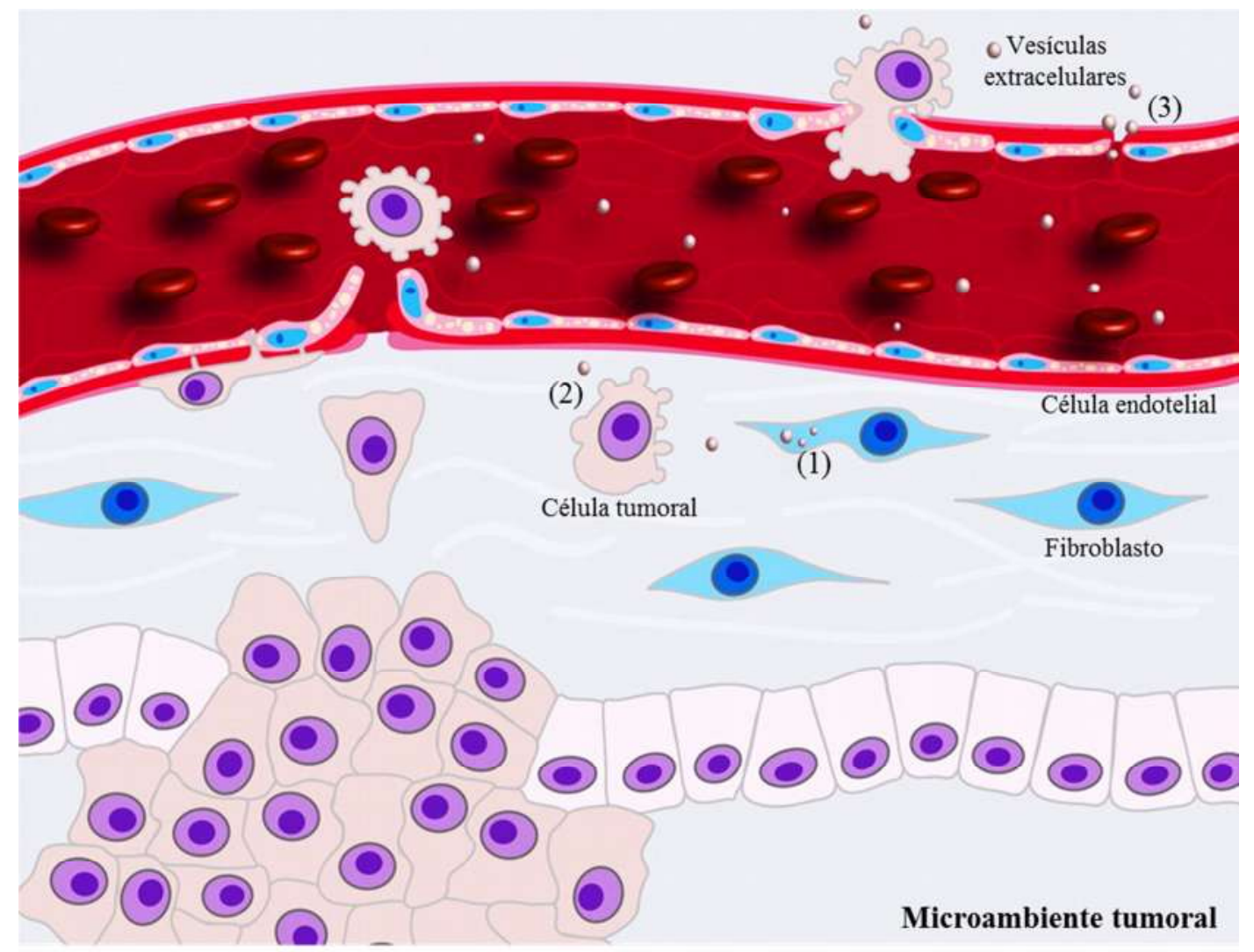

Figura 3 - Vesículas extracelulares derivadas de células tumorais podem modular o microambiente tumoral. (1) Vesículas extracelulares de células tumorais podem interagir com as células estromais, por exemplo, o fibroblasto, levando a modificação no comportamento destas células alvo; (2) Também podem interagir com a MEC através da deposição de seu conteúdo ou promover a degradação da matriz, facilitando o trajeto da célula; (3) Vesículas podem estar relacionadas com a progressão, invasão e metástase tumoral. Adaptado de (D'SOUZA-SCHOREY; CLANCY, 2012).

Existem diferentes metodologias e diversas amostras biológicas que são usadas para investigar a biologia das vesículas extracelulares. Deste modo, surgem diversos protocolos e heterogêneas interpretações dos resultados, tornando-se necessário o uso de marcadores específicos para cada tipo de vesícula. Esta, seria uma maneira possível de padronizar as vesículas extracelulares, principalmente após comparação com os bancos de dados já existentes na literatura (LÖTVALL et al., 2014).

\subsubsection{Nomenclatura das vesículas}

A variedade de vesículas extracelulares liberadas por diversas células levou a contradições quanto à sua nomenclatura, surgindo assim diversas terminologias 
(COCUCCI; RACCHETTI; MELDOLESI, 2009; VAN DER POL et al., 2012). Dentre elas estão as que se referem ao tamanho (microvesícula, micropartícula, nanopartícula); as que se referem ao tecido ou tipo celular de origem (oncossomo, prostassomo); aquelas cuja presença seria fora (prefixo “exo" ou “ecto") da célula (exossomo, vesícula semelhante à exossomo, exovesícula, ectossomo); algumas relacionadas a supostas funções (argossomo, vesícula de matriz, epididimossomo, tolerossomo, prominossomo, dexossomo, texossomo); além de vesículas de membrana extracelular e vesículas (bolhas ou corpos) apoptóticas (COCUCCI; MELDOLESI, 2015; COLOMBO; RAPOSO; THÉRY, 2014; KIM, D. K. et al., 2015; MATHIVANAN; JI; SIMPSON, 2010).

A maioria destas nomenclaturas refletem as funções específicas de cada tipo de vesícula ou mesmo ao tipo celular de origem, por exemplo, "tolerossomo", vesícula que induz a tolerância do sistema imune à antígenos alimentares (KARLSSON et al., 2001); “prostassomo", vesícula de próstata (GOULD; RAPOSO, 2013; STEGMAYR; RONQUIST, 1982); existem também "vesículas que auxiliam na calcificação da matriz”, iniciando a formação óssea (ANDERSON, 1969; GOULD; RAPOSO, 2013).

O termo "exossomo" vem sendo utilizado de maneiras diferentes, como: vesículas de endossomos, que são liberadas após a fusão de corpos multivesiculares com a membrana plasmática; ou ainda, como vesículas que possuem alguma "função biológica". Outro exemplo é com relação ao termo "microvesícula", que é sendo usado como: vesícula que surge a partir do brotamento direto da membrana plasmática (GOULD; RAPOSO, 2013). A partir de 2004, o termo "exossomo" é frequentemente usado em artigos científicos, sendo que, o termo "vesículas extracelulares", foi escolhido como termo genérico, e está em constante uso (LÖTVALL et al., 2014). Atualmente, o termo "vesículas extracelulares" se tornou o mais recomendado, visto que, ainda não há um consenso na literatura sobre a nomenclatura correta para as vesículas liberadas para o ambiente extracelular (GOULD; RAPOSO, 2013). No presente trabalho, adotamos o termo "vesículas extracelulares".

\subsubsection{Diversidade de vesículas}

Existem vesículas que participam do tráfego intracelular ou entre compartimentos celulares, denominadas vesículas transportadoras e secretoras; outras vesículas 
(microvesículas) são formadas a partir da membrana plasmática por brotamento direto; outras, são formadas no interior dos compartimentos celulares internos (endossomos precoces) e são posteriormente secretadas pela fusão destes compartimentos com a membrana plasmática; vesículas extracelulares como os exossomos, são geradas em endossomos tardios ou corpos multivesiculares, e posteriormente secretados para meio extracelular (COCUCCI; MELDOLESI, 2015; THÉRY; OSTROWSKI; SEGURA, 2009). A liberação de vesículas extracelulares através do brotamento direto, resulta na perda de pequenos fragmentos da membrana plasmática, pelo qual a célula providencia medidas para manter o equilíbrio da membrana, como a exocitose de vesículas intracelulares (COCUCCI; MELDOLESI, 2015). Na figura abaixo, pode ser observada a diversidade de vesículas:

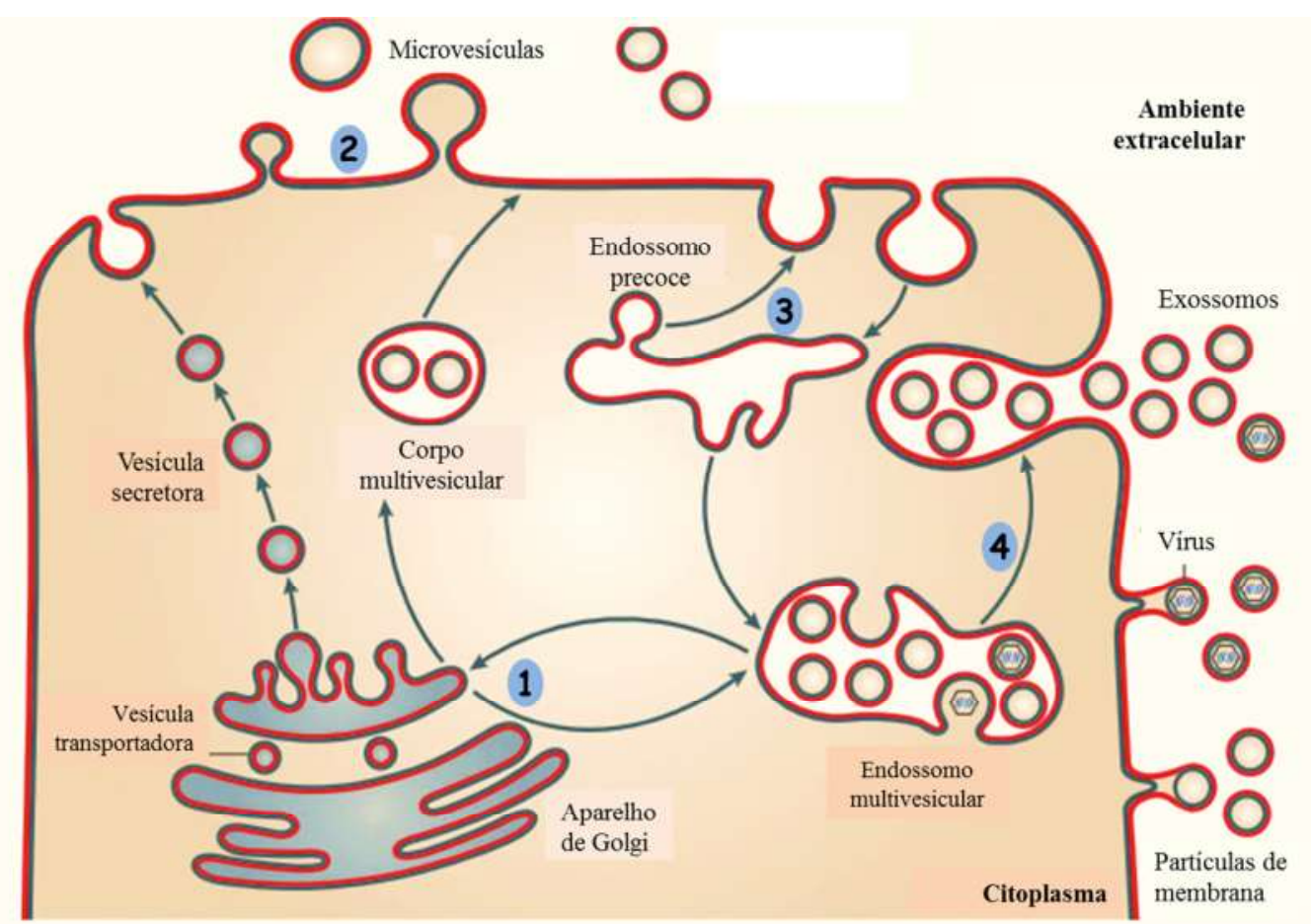

Figura 4 - Diversidade de vesículas liberadas pelas células. 1: vesículas que participam do tráfego intracelular ou entre compartimentos celulares, denominadas vesículas transportadoras e secretoras; 2: vesículas como, microvesículas, vírus envelopados (como retrovírus) e partículas de membranas, são formadas a partir da membrana plasmática por brotamento direto; 3: vesículas advindas de endossomos precoces, são formadas no interior dos compartimentos celulares internos e são posteriormente secretadas por fusão destes compartimentos com a membrana plasmática; 4: vesículas extracelulares como os exossomos, são gerados em endossomos tardios ou corpos multivesiculares, e posteriormente secretados. Adaptado de (THÉRY; OSTROWSKI; SEGURA, 2009). 
De modo geral, os termos mais usados para classificar as vesículas extracelulares são: exossomos, microvesículas e corpos apoptóticos (EL ANDALOUSSI et al., 2013; GYÖRGY et al., 2011; THÉRY; OSTROWSKI; SEGURA, 2009; VADER; BREAKEFIELD; WOOD, 2014). A figura abaixo representa esta classificação das vesículas extracelulares:

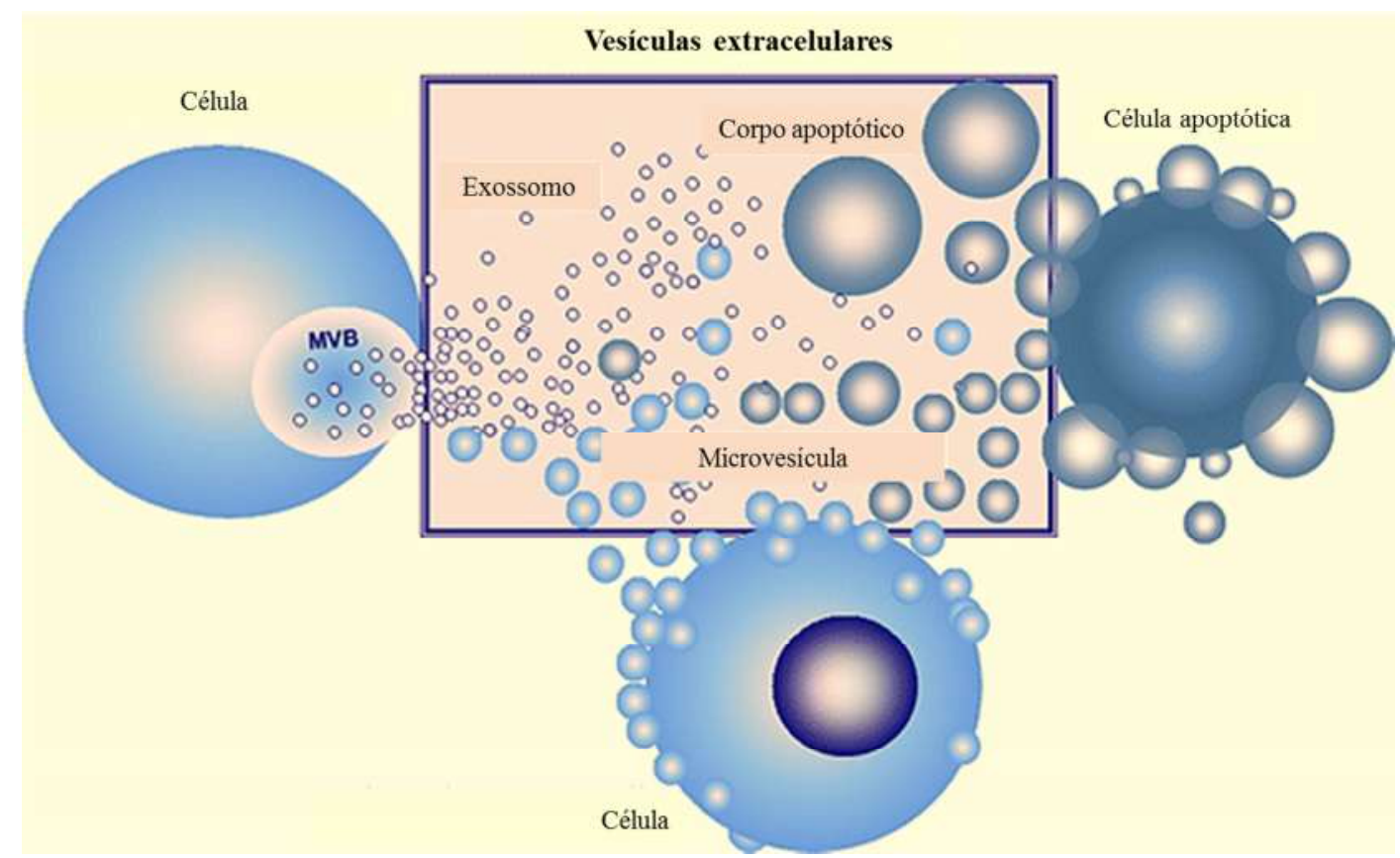

Figura 5 - Representação esquemática das vesículas extracelulares. As principais populações incluem exossomos, microvesículas e corpos apoptóticos. Para simplificar a figura, as células não foram mostradas liberando todos os tipos de vesículas. MVB: do inglês, "multivesicular body". Adaptado de (GYÖRGY et al., 2011).

Os exossomos foram descritos pela primeira vez por Trams e colaboradores, em 1981 (TRAMS et al., 1981). A origem endossomal é um critério comumente utilizado para definir os exossomos; estruturas de morfologia arredondada e bem delimitada, de tamanho entre 30 e $100 \mathrm{~nm}$ de diâmetro, similar ao tamanho de vírus (Figura 6). Exossomos podem ser liberados tanto constitutivamente como após a indução do processo de exocitose de corpos multivesiculares, assim, são secretados após a fusão destes corpos com a membrana plasmática (Figura 4). Deste modo, podem apresentar membrana celular e componentes citosólicos em sua composição. Devido sua origem, possuem proteínas envolvidas na via endossomal-lisossomal, e estas, são utilizadas 
como marcadores de exossomos (CONDE-VANCELLS et al., 2008; GYÖRGY et al., 2011; ROBBINS; MORELLI, 2014; THÉRY; ZITVOGEL; AMIGORENA, 2002). Os exossomos podem exercer as suas funções biológicas nas células através do contato direto entre as moléculas da superfície celular e a vesícula; processo de endocitose de vesículas; e fusão da membrana da célula e a vesícula (GYÖRGY et al., 2011).

As microvesículas foram descritas pela primeira vez por Chargaff e West, em 1946 como um precipitado observado em plasma sanguíneo (GYÖRGY et al., 2011). Em 1967, Wolf também observou a presença de partículas após ultracentrifugação de plasma sanguíneo humano (WOLF, 1967). O brotamento direto a partir da membrana plasmática das células é aplicado para microvesículas, vesículas de forma e tamanho mais heterogêneo, em geral, maior que $100 \mathrm{~nm}$ (COCUCCI; RACCHETTI; MELDOLESI, 2009; DUBREUIL et al., 2007; EL ANDALOUSSI et al., 2013; OHNO; ISHIKAWA; KURODA, 2013; THÉRY; OSTROWSKI; SEGURA, 2009; TURIÁK et al., 2011; VADER; BREAKEFIELD; WOOD, 2014). Diferente dos exossomos, as microvesículas não estão envolvidas com a via endocítica (DE MAIO, 2011). Seu tamanho sobrepõe ao tamanho de bactérias e agregados proteicos (Figura 6). A liberação de microvesículas pode ser induzida após a ativação de receptores da superfície celular ou apoptose e consequente aumento de fluxo de $\mathrm{Ca}^{2+}$ intracelular (GYÖRGY et al., 2011). Também ocorre perda de assimetria de fosfolipídios da membrana plasmática, exposição de fosfatidilserina e alterações no citoesqueleto; levando a formação da curvatura da membrana e assim, a liberação da vesícula para o meio extracelular (D'ASTI et al., 2012). Contudo, a maioria dos estudos são sobre os exossomos, poucos são sobre a caracterização das microvesículas.

O termo corpo apoptótico foi utilizado pela primeira vez por Kerr e colaboradores, em 1972. Estes corpos são considerados como estruturas com tamanhos heterogêneos entre 1 e $5 \mu \mathrm{m}$, liberados após a fragmentação de células em processo apoptótico (GYÖRGY et al., 2011; TURIÁK et al., 2011). Corpos apoptóticos podem conter organelas citoplasmáticas e/ou fragmentos nucleares, enquanto que microvesículas não apresentam estas estruturas (MURALIDHARAN-CHARI et al., 2010; TAYLOR; CULLEN; MARTIN, 2008; VADER; BREAKEFIELD; WOOD, 2014). O tamanho dos principais tipos de vesículas extracelulares está representado na figura abaixo: 


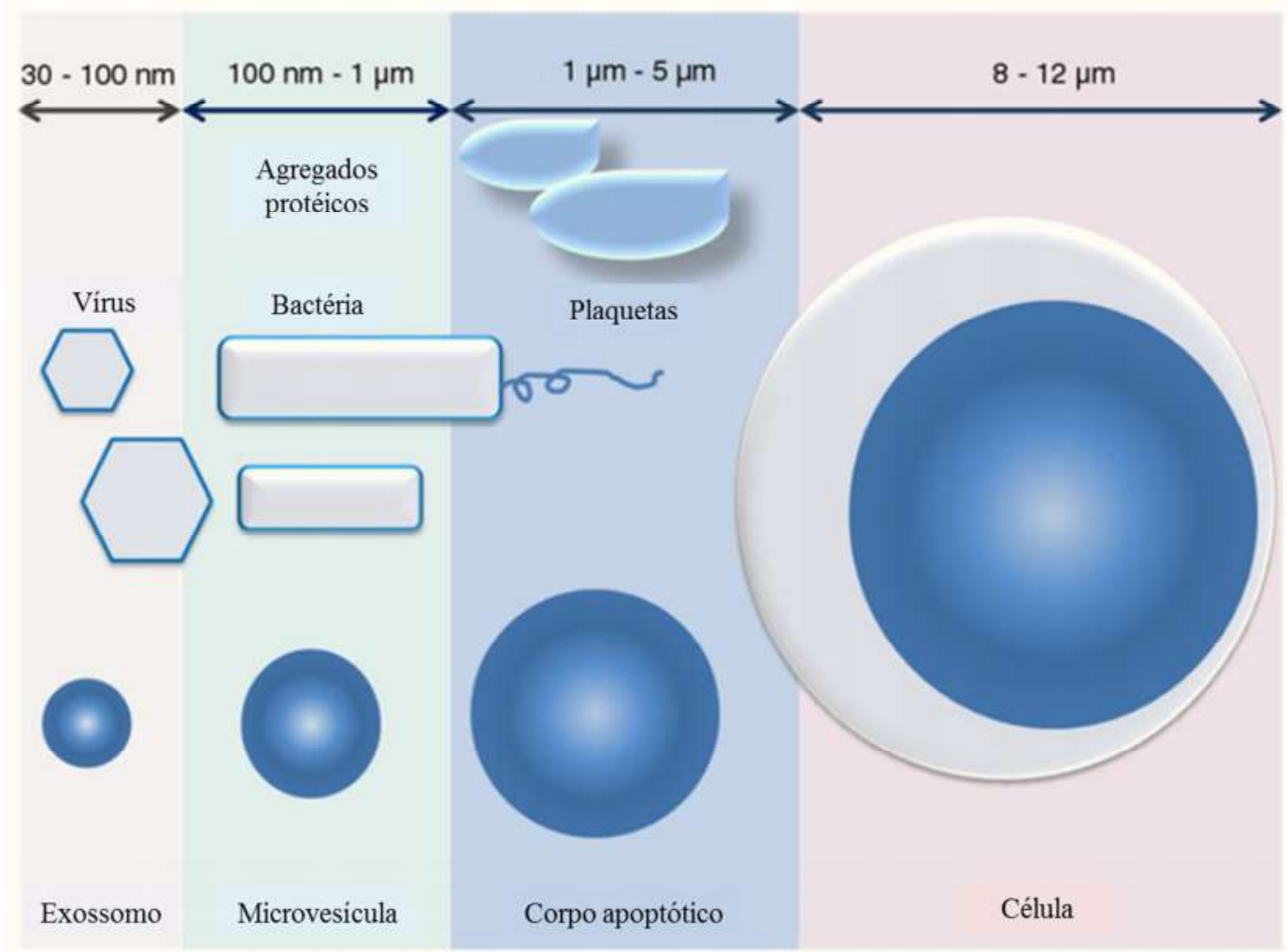

Figura 6 - Tamanho dos principais tipos de vesículas extracelulares. Enquanto exossomos compartilham uma distribuição de tamanho com os vírus, as microvesículas sobrepõem em tamanho, com as bactérias e os agregados proteicos (por exemplo, complexos imunes). Corpos apoptóticos e plaquetas possuem tamanho entre 1 e $5 \mu \mathrm{m}$. Adaptado de (GYÖRGY et al., 2011).

\subsubsection{Isolamento e análises de vesículas extracelulares}

$\mathrm{Na}$ literatura, ainda não está totalmente estabelecido um protocolo para isolar vesículas extracelulares. Em geral, os métodos de isolamento e análise de exossomos são: centrifugação diferencial, seguida de ultracentrifugação em gradiente de densidade utilizando sacarose, com até 100.000 g (GOULD; RAPOSO, 2013; KRUGER et al., 2014; THÉRY et al., 2006), ou mesmo, reagentes comerciais, como ExoQuick (System Biosciences, EUA) (GYÖRGY et al., 2011). Os métodos mais usados de isolamento de microvesículas são através de centrifugações mais baixas, a partir de $10.000 \mathrm{~g}$ (GOULD; RAPOSO, 2013; MURALIDHARAN-CHARI et al., 2009; YUANA; STURK; NIEUWLAND, 2013).

Existem contradições sobre os métodos de isolamento de vesículas usando centrifugação (tempo, força, números de ciclos, outros). Outro fator é a ampla 
distribuição de tamanhos das vesículas extracelulares. Alguns protocolos indicam a filtração da amostra usando membrana de poro de $0,2 \mu \mathrm{m}$ (para isolar exossomos) ou $0,8 \mu \mathrm{m}$ (para isolar microvesículas) no caso de sobrenadantes celulares, para a remoção de células e debris (COCUCCI; MELDOLESI, 2015; GYÖRGY et al., 2011; THÉRY; ZITVOGEL; AMIGORENA, 2002). No entanto, uma rápida filtração pode levar à fragmentação das vesículas, e para evitar este problema recomenda-se a filtração por gravidade (GYÖRGY et al., 2011). Alguns tipos de centrifugações aplicam 200 a 1500 g para remover restos celulares; 10.000 a 20.000 g para sedimentar e isolar vesículas maiores que $100 \mathrm{~nm}$; e 100.000 a 200.000 g para isolar vesículas menores que $100 \mathrm{~nm}$ (VAN DER POL et al., 2012) sem passar pela etapa de filtração. A centrifugação diferencial ainda é um método difícil, devido às distribuições de tamanho e as diferentes populações de vesículas extracelulares. Neste caso, utiliza-se gradiente de sacarose, sendo possível separar exossomos de microvesículas, devido à diferença na densidade das vesículas (GYÖRGY et al., 2011; THÉRY; OSTROWSKI; SEGURA, 2009).

Outro método usado para o isolamento de vesículas é através de imunoafinidade, usando esferas revestidas de anticorpos específicos para vesículas extracelulares (HANNAFON; DING, 2013).

Ainda é complicado determinar os componentes ou marcadores moleculares específicos dos diferentes tipos de vesículas extracelulares (COLOMBO; RAPOSO; THÉRY, 2014; DE MAIO, 2011). É possível analisar e caracterizar as proteínas das vesículas extracelulares através da análise proteômica, usando técnica de espectrometria de massa (COCUCCI; MELDOLESI, 2015; D'SOUZA-SCHOREY; DI VIZIO, 2014; GYÖRGY et al., 2011;). Algumas proteínas podem ser específicas conforme: o tipo de vesícula analisada, tipo celular a qual a vesícula foi isolada, ou mesmo o tipo de centrifugação utilizada para isolar a mesma. Também é plausível realizar a quantificação de proteínas das vesículas através de "immunoblot" (COLOMBO; RAPOSO; THÉRY, 2014; GYÖRGY et al., 2011).

A citometria de fluxo pode ser usada para analisar o tamanho e composição das vesículas extracelulares, tornando possível detectar apenas vesículas maiores de 200 $\mathrm{nm}$. Exossomos e microvesículas menores não podem ser analisadas (ARAKELYAN et al., 2014; GYÖRGY et al., 2011).

Com relação ao tamanho das vesículas, também pode ser usada a microscopia eletrônica de transmissão (MET) ou a microscopia de força atômica, uma variante da 
microscopia eletrônica de varredura, para visualizar e analisar estas estruturas (GYÖRGY et al., 2011; LÖTVALL et al., 2014).

A distribuição do tamanho e a concentração das vesículas presentes em um determinado fluido também podem ser observadas após análise de rastreamento de nanopartículas, utilizando por exemplo, o NanoSight. Esse equipamento utiliza as propriedades de espalhamento de luz das partículas em um meio fluído. O NanoSight detecta estruturas entre 10-2000 nm de diâmetro (COCUCCI; MELDOLESI, 2015; LÖTVALL et al., 2014).

Os corpos apoptóticos não são isolados, em geral, utiliza-se ensaios de co-culturas de células apoptóticas para investigar as funções destas estruturas, visto que estas estruturas são bem maiores (como representado na Figura 6), com diâmetro entre 1 a 5 $\mu \mathrm{m}$ (GYÖRGY et al., 2011). Estas estruturas também podem ser observadas através de imagens após técnica de imunofluorescência (LÖTVALL et al., 2014).

A microscopia de fluorescência também é usada para visualizar vesículas, diretamente em lamínulas ou dentro das células. Vesículas menores $(<100 \mathrm{~nm})$ também podem ser observadas, visto que o limite de resolução dos microscópios ópticos clássicos é de $200 \mathrm{~nm}$, e em geral são vistas como agregados de vesículas (COLOMBO; RAPOSO; THÉRY, 2014).

Por fim, independente da técnica usada para analisar as vesículas extracelulares, cada método deve ser optimizado para o tipo de amostra biológica em questão, podendo até mesmo, ser necessário a utilização de várias metodologias para examinar as características físicas e morfológicas, bem como a composição, destas estruturas vesiculares (COLOMBO; RAPOSO; THÉRY, 2014). Além de que, muitas dessas técnicas ainda necessitam de otimização para o estudo de vesículas extracelulares.

\subsubsection{Conteúdo das vesículas extracelulares}

A função das vesículas extracelulares parece ser dependente do conteúdo que transportam. Este conteúdo, por sua vez, depende do tipo celular pelo qual foi originado (MURALIDHARAN-CHARI et al., 2010) e ainda, no caso de ensaios in vitro, depende das condições de cultivo das células (CHOI et al., 2015). As vesículas extracelulares podem transferir seu conteúdo para uma célula alvo. Esta célula receptora pode apresentar novas funções após receber o conteúdo através da vesícula (D'ASTI et al., 
2012; MATHIVANAN; JI; SIMPSON, 2010; ROBBINS; MORELLI, 2014). Microvesículas e exossomos estão envolvidas no processo de sinalização intracelular, devido a presença de diferentes moléculas, em seu conteúdo (DUBREUIL et al., 2007; SANDVIG; LLORENTE, 2012; TURIÁK et al., 2011).

A composição geral das vesículas extracelulares está representada por: proteínas citoplasmáticas e de membrana, como selectinas e integrinas, bem como seus receptores (EL ANDALOUSSI et al., 2013; OHNO; ISHIKAWA; KURODA, 2013; THÉRY; OSTROWSKI; SEGURA, 2009), lipídios (fosfatidilserina, esfingomielina e colesterol) e ácidos nucleicos (mRNA e miRNA) (CHOI et al., 2015; COLOMBO; RAPOSO; THÉRY, 2014), como está representado na Figura 7. miRNA são pequenas moléculas de RNA, não codificadores de proteínas, que agem como reguladores póstranscricionais da expressão gênica. miRNA desempenham importante papel em diversos processos biológicos, como na tumorigênese (LI et al., 2009). As vesículas extracelulares das células tumorais também apresentam em seu conteúdo o miRNA, pelo qual tornaram-se biomarcadores do câncer, pois podem levar a caracterização da origem e do desenvolvimento de tumores (GYÖRGY et al., 2011). Além disso, miRNAs podem ativar moléculas de sinalização e receptores da célula alvo (YOON; KIM; GHO, 2014).

Atualmente existem dois bancos de dados que agrupam informações a respeito da composição das vesículas extracelulares (proteínas, ácidos nucleicos e lipídios): "EVpedia" (http://evpedia.info) (KIM, D. K. et al., 2015) e "Vesiclepedia" (http://microvesicles.org) (KALRA et al., 2012); estes bancos são atualizados constantemente por grupos de pesquisadores (COLOMBO; RAPOSO; THÉRY, 2014). Vesículas extracelulares foram caracterizadas com sucesso, por análise proteômica utilizando espectrometria de massa (COCUCCI; MELDOLESI, 2015; D'SOUZASCHOREY; DI VIZIO, 2014;).

Como mencionado, a metodologia mais usada para analisar e caracterizar as proteínas das vesículas extracelulares é a análise proteômica. Em geral, as proteínas vesiculares são advindas de vesículas internas, membrana plasmática e citoplasma (CHOI et al., 2015). Dentre as principais proteínas mais encontradas em vesículas extracelulares estão: proteínas de transporte de membrana (anexinas, flotilins, proteínas Rab, TSG101); proteínas apresentadoras de antígeno (MHC, do inglês, "major histocompatibility complex"); proteínas adesivas (tetraspaninas, integrinas, outras); 
proteínas de membrana (LAMP, do inglês, "lysosome-associated membrane protein"; TfR, do inglês, "transferrin receptor"); proteínas citosólicas (histonas, ribossomais e proteínas de choque térmico - HSP, do inglês "heat shock protein"); proteínas de citoesqueleto (actina, tubulina, dentre outras) (CHOI et al., 2015; COLOMBO; RAPOSO; THÉRY, 2014). A figura abaixo exemplifica os principais componentes já encontrados nas vesículas extracelulares:

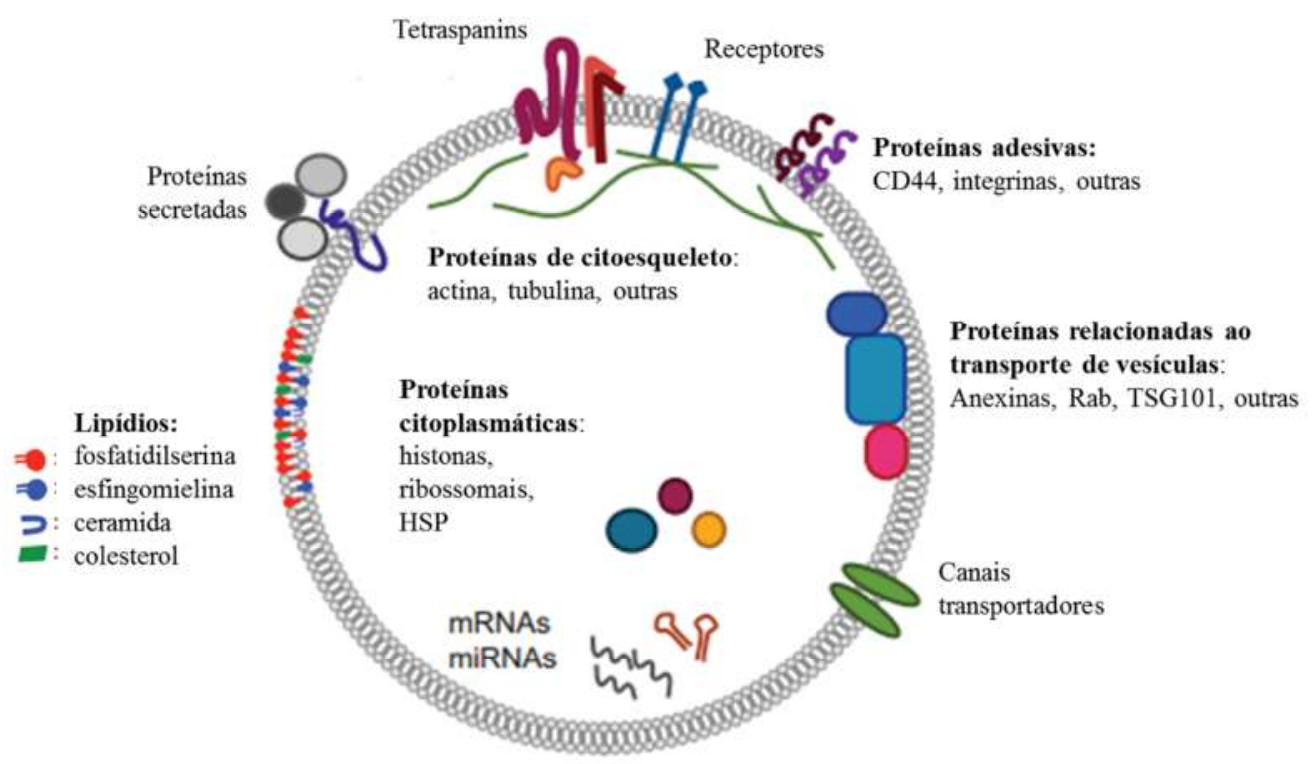

Figura 7 - Vesícula extracelular e seus principais componentes. A composição geral das vesículas extracelulares está representada por: proteínas citoplasmáticas, de citoesqueleto, de membrana e seus receptores; além de proteínas de transporte de vesículas, proteínas apresentadoras de antígeno, proteínas adesivas (tetraspaninas, integrinas); lipídios e ácidos nucleicos (mRNA e miRNA). Adaptado de (CHOI et al., 2015).

Kruger e colaboradores (2014) isolaram vesículas semelhantes à exossomos de células tumorais de mama (MDA-MB-231 e MCF-7) e as proteínas mais encontradas foram: actina, anexinas (A1, A2, A5), isozimas piruvato kinase (M1/M2), tubulina ( $\beta$ e $\alpha$ ), proteína de choque térmico (HSP $90 \alpha$ ), histona (H4), integrina $\alpha-2$, entre outras. A análise proteômica identificou em vesículas derivadas de células MCF-7, mesmo que de maneira menos relevante, as proteínas AHNAK e mioferlina (KRUGER et al., 2014). 


\subsection{Proteína AHNAK}

AHNAK ("Neuroblast differentiation-associated protein"), também conhecida como, “desmoyokin" é uma molécula grande (com aproximadamente $700 \mathrm{kDa}$ ). Tanto o mRNA como a proteína já foram identificadas em vários tipos celulares. Devido à sua grande estrutura, AHNAK pode ser clivada em vários locais diferentes (DAVIS; LOOS; ENGELBRECHT, 2014).

A proteína AHNAK está associada à interações proteína-proteína, devido aos seus vários locais de ligação. A estrutura de proteína AHNAK possui natureza tripartida: domínios N-terminais com 251 aminoácidos de tamanho; unidades repetidas centrais que apresentam cerca de 4390 aminoácidos de 26 elementos repetidos e domínio Cterminal, que contém 1002 aminoácidos (DAVIS; LOOS; ENGELBRECHT, 2014; HUANG et al., 2007).

AHNAK faz parte de uma estrutura chamada "enlargeossomo", que foi descrito em neurônios e está associada ao aumento de vesículas citoplasmáticas dependente da superfície de células em exocitose (BORGONOVO et al., 2002; DAVIS; LOOS; ENGELBRECHT, 2014; LORUSSO et al., 2006; RACCHETTI et al., 2010). AHNAK pode apresentar diferentes funções entre os vários tipos celulares, por exemplo, modulação do reparo da membrana muscular e regulação dos canais de cálcio cardíacos (DAVIS; LOOS; ENGELBRECHT, 2014; HASHIMOTO et al., 1993; HUANG et al., 2007). Além do papel no enlargeossomo, AHNAK também é importante, na altura da célula e manutenção do citoesqueleto (BENAUD et al., 2004). No entanto, outro estudo mostrou que animais deficientes de AHNAK apresentaram efeito mínimo sobre o desenvolvimento geral, tumorigênese, adesão de células epidérmicas, proliferação e diferenciação celular, bem como, na manutenção da integridade da epiderme de camundongos (KOUNO et al., 2004).

AHNAK foi identificada em uma diversidade de tipos celulares em ambos os níveis de mRNA e proteína; e sua distribuição pode ser diferenciada de acordo com o tipo celular. AHNAK já foi encontrada em núcleos e aparelho de Golgi de células não epiteliais (SHTIVELMAN; BISHOP, 1993), no entanto, também já foi descrita como predominantemente de localização citoplasmática ou associada à membrana plasmática de células epiteliais (SUSSMAN et al., 2001). Hashimoto e colaboradores (2003) observaram que em queratinócitos AHNAK foi encontrada na membrana celular, ao 
contrário da maioria das outras células, em que AHNAK esta distribuída no citoplasma (HASHIMOTO et al., 1993). A localização de AHNAK na membrana plasmática possivelmente seria devido às suas interações específicas com proteínas Anexina A2 e S100A10, pois AHNAK não apresenta domínios transmembrânicos (BENAUD et al., 2004; GENTIL et al., 2003; HUANG et al., 2007). Isto sugere que a proteína AHNAK é uma molécula global, com uma estrutura exclusiva e de diversificada distribuição.

A proteína AHNAK já foi encontrada altamente expressa em linhagens celulares de mesotelioma (SUDO et al., 2014); após proteômica, AHNAK foi identificada em linhagens tumorais de mama (MDA-MB-231 e MDA-MB-435), células tumorais de próstata (DU145), de fibrossarcoma (HT1080), além de linhagens de glioma (U251 e U87) (SHANKAR et al., 2010).

Apesar da identificação prévia da proteína ou mRNA de AHNAK em estudos de vesículas extracelulares, o papel desempenhado por essa molécula em vesículas derivadas de câncer de mama permanece indefinida. 


\section{OBJETIVOS}

\subsection{Objetivo geral}

Analisar as interações entre células estromais (fibroblastos não tumorais) e células tumorais da mama, bem como, caracterizar as estruturas vesiculares derivadas de células tumorais de mama.

\subsection{Objetivos específicos}

- Analisar como as vesículas podem influenciar a relação de células estromais e células tumorais in vitro, através de co-cultura;

- Comparar o número de vesículas liberadas por células normais e tumorais;

- Verificar o papel de vesículas derivadas de células tumorais (MDA-MB-231) na proliferação celular de linhagens de mama (tumorais ou não);

- Identificar proteínas presentes em vesículas extracelulares através de espectrometria de massas;

- Avaliar o efeito da proteína AHNAK na proliferação, migração e invasão celular, bem como, na liberação e troca de vesículas com fibroblastos não tumorais.

- Verificar a expressão de AHNAK em tecidos mamário humanos normal e tumoral. 


\section{MATERIAL E MÉTODOS}

\subsection{Linhagens celulares e condições de cultivo}

As linhagens celulares de adenocarcinoma de mama humana MDA-MB-231 e MCF-7 foram cultivadas em meio de Eagle modificado por Dulbecco/Misturado com nutriente F-12 (DMEM-F12, Sigma Chemical Co, St. Louis, MO, USA), suplementado com 10\% de soro fetal bovino (SFB - Cultilab, SP, Brasil).

Os fibroblastos não tumorais foram obtidos de culturas primárias, utilizando tecido de mama humano normal, proveniente de mamoplastia estética de uma paciente de 22 anos, o protocolo foi aprovado pela Comissão de Ética em Pesquisa Envolvendo Seres Humanos - CEPSH do ICB-USP (Parecer 1017/CEP).

Os fibroblastos foram cultivados em meio de Eagle modificado por Dulbecco (DMEM, Sigma), suplementado com 10\% de SFB, ácido ascórbico (1:10, Sigma), solução de penicilina (5 U/ml) e estreptomicina ( $5 \mu \mathrm{g} / \mathrm{ml})$ (Gibco®), Life Technologies, Eugene, Oregon, USA).

Células não tumorais de mama humana, MCF-10A foram usadas em ensaios de proliferação celular. Estas células, derivadas de epitélio mamário normal, foram cultivadas em DMEM-12 (Sigma) suplementado com 5\% de soro de cavalo (Gibco®, Life Technologies), $20 \mathrm{ng} / \mathrm{ml}$ de fator de crescimento epidérmico (EGF), 0,5 $\mu \mathrm{g} / \mathrm{ml} \mathrm{de}$ hidrocortisona, $10 \mu \mathrm{g} / \mathrm{ml}$ de insulina e $100 \mathrm{ng} / \mathrm{ml}$ de toxina colérica.

As células foram mantidas em frascos de $75 \mathrm{~cm}^{2}$ a $37{ }^{\circ} \mathrm{C}$, em atmosfera umidificada contendo $5 \%$ de $\mathrm{CO}_{2}$. O crescimento das células foi monitorado diariamente em microscópio invertido de contraste de fase, e o meio de cultura trocado a cada 2 ou 3 dias, de acordo com o metabolismo celular. Após atingirem a subconfluência, as células foram subcultivadas. Amostras representativas da cultura foram posteriormente congeladas e mantidas em recipientes contendo nitrogênio líquido, crio-protegidas com 10\% de dimetil sulfóxido (DMSO - Sigma).

\subsection{Co-cultura}

Ensaios de co-cultura foram realizadas com o objetivo de analisar as interações entre as células tumorais de mama e estromais, bem como verificar o comportamento 
das células in vitro. Estes ensaios consistiram de um sistema de análise de células tridimensional.

Células do estroma (fibroblastos não tumorais de mama) foram co-cultivadas com células tumorais de mama em lamínulas de vidro. Os fibroblastos foram co-cultivados em contato direto com as células tumorais, como descrito a seguir. Após os fibroblastos atingirem 90\% de confluência foram corados com corante verde (Cell Tracker TM “green” CMFDA (C7025), AM, Life Technologies) e células de mama (MDA-MB-231 ou MCF-7) previamente evidenciadas com corante vermelho (Cell Tracker TM "Orange" CMRA (C34551), AM, Life Technologies) foram plaqueadas sobre a monocamada de fibroblastos. Os corantes Cell Tracker TM foram carregados nas células vivas através da adição do mesmo em meio de cultura, e logo após incubação (30 minutos), as células foram lavadas com meio de cultura. Este produto tem como característica a capacidade de atravessar passivamente a membrana celular e uma vez no interior da célula, fica impedido de migrar para o meio extracelular devido à incorporação do produto pela célula e consequente impermeabilidade celular. Assim, o corante pode ficar retido na célula viva por várias gerações, sendo herdado pelas células filhas após a fusão celular, mas não é transferido para células adjacentes em uma população. O corante contém um grupo clorometil que reage com tióis em uma reação mediada pela enzima glutationa-Stransferase intracelular. $\mathrm{O}$ corante verde não é fluorescente, até atuar com esterases e depois reagir com a enzima intracelular. Deste modo, o excesso de reagente não conjugado difunde passivamente para o meio extracelular (Dados do fabricante, Life Technologies).

Após a adesão das células epiteliais (24 horas), o meio foi removido e substituído por meio sem SFB. Após 24 horas, as células foram fixadas em 4\% de paraformaldeído (PFA) em tampão fosfato salino (PBS 1X) e o núcleo foi marcado com "ProLong" com "DAPI" (Life Technologies). 


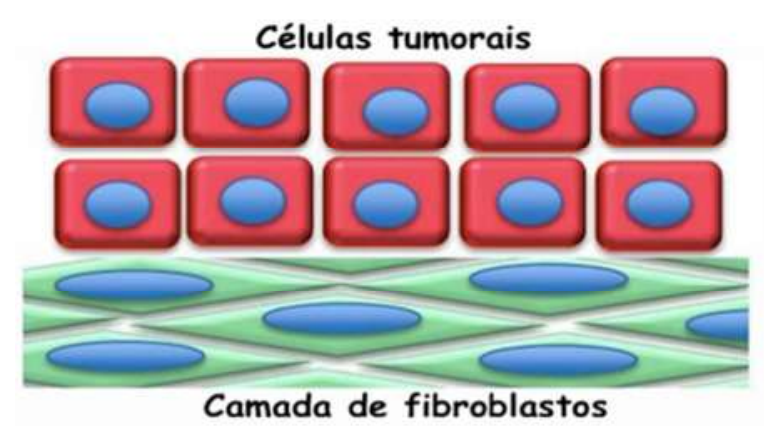

Figura 8 - Esquema da co-cultura com fibroblastos não tumorais e células tumorais de mama

As amostras de co-cultura foram analisadas no microscópio confocal Zeiss LSM 780 NLO (CEFAP-ICB) utilizando o software ZEN 2011 com a objetiva de 63X abertura numérica de 1.4, imagens dos canais verde, vermelho e azul foram capturados. Especial atenção foi dada a interação entre as duas linhagens, tais como, os prolongamentos emitidos, presença e troca de vesículas por essas células.

\subsubsection{Quantificação de vesículas trocadas pelas células}

Utilizando o software ZEN 2011 foi possível quantificar o número de vesículas trocadas pelas células que foram co-cultivadas. Neste software, a imagem foi aberta em plano ortogonal, na ampliação de $100 \%$ e com ajustes das posições X, Y e Z, a posição da vesícula foi verificada. As vesículas vermelhas internalizadas pelas células verdes e vice-versa foram então contadas.

\subsection{Análise de estruturas vesiculares}

Para a análise de estruturas vesiculares obtidas nos ensaios de co-cultura foi realizada a visualização das células usando microscopia eletrônica de transmissão (MET). Vesículas isoladas também foram visualizadas por MET, analisadas por NanoSight, por métodos proteômicos e por "Immunoblot". E ainda foram observadas vesículas em células através de microscopia eletrônica de varredura (MEV). Também 
foi realizado ensaio de imunolocalização de vesículas em co-cultura e em monocultura de células, localizando assim a principal proteína identificada na proteômica.

3.3.1. Isolamento das estruturas vesiculares das células tumorais de mama MDA-MB231 e análise através de MET

O ensaio foi realizado com células tumorais MDA-MB-231 (10 $0^{7}$ células) cultivadas em frascos de $150 \mathrm{~cm}^{2}$, em meio contendo $10 \%$ de SFB. As células foram mantidas a $37{ }^{\circ} \mathrm{C}$ em estufa contendo $5 \%$ de $\mathrm{CO}_{2}$, até atingirem $90 \%$ de confluência celular. Após, o meio das células foi substituído por meio sem soro e mantidas a $37{ }^{\circ} \mathrm{C}$ por mais 24 horas.

Após 24 horas, o meio condicionado $(15 \mathrm{ml})$ foi filtrado, em filtro de poro de 0,8 $\mu \mathrm{m}$ (Corning ${ }^{\circledR}, \mathrm{NY}, \mathrm{USA}$ ) para remoção de debris e células não viáveis, e adicionado inibidor de protease (2 $\mathrm{mM} 4$-(2-aminoetil) de fluoreto de benzenossulfonil (AEBSF); $0,3 \mu \mathrm{M}$ de aprotinina; $130 \mathrm{mM}$ de bestatina; $14 \mathrm{mM}$ de E-64; $1 \mathrm{mM}$ de leupeptina e 1 $\mathrm{mM}$ de EDTA de sódio; Sigma). O meio condicionado foi centrifugado a $15000 \mathrm{~g}$, por 30 minutos, a $4{ }^{\circ} \mathrm{C}$ (conforme Figura 11 A). Após, o sobrenadante foi descartado. E o "pellet" obtido foi ressuspendido em PBS $(5 \mu \mathrm{l})$ e gotejado sobre tela de cobre revestida com película de carbono (CF100-cu "carbon film", Electron Microscopy Sciences EMS, Hatfield PA, USA). Esta tela com rede quadrada é capaz de acomodar este tipo de amostra, pois apresenta em um de seus lados, a película de carbono. A amostra foi incubada a temperatura ambiente, durante a noite. Em seguida, a tela com a amostra foi lavada com PBS e colocado sob a mesma 2,5\% de glutaraldeído, e incubado a temperatura ambiente por 5 minutos. Após, por imersão, a tela foi lavada com água destilada, várias vezes. O contraste foi realizado com $1 \%$ de acetado de uranila, incubado a temperatura ambiente, por 5 minutos. Em seguida, a tela foi lavada com PBS e armazenada a temperatura ambiente, durante a noite. E então foi realizada a análise por MET.

Quando as vesículas isoladas foram utilizadas em ensaios funcionais (proliferação celular), o meio condicionado pelo qual foi feito o isolamento, não recebeu inibidor de protease.

\subsubsection{Análise das células por MET}


Após a adesão das células epiteliais (24 horas), o meio foi removido e substituído por meio sem SFB e incubadas por 24 horas. Logo após, as células foram lavadas com PBS 1X, removidas da placa com raspadores (Cell Scraper, Corning®) e fixadas com 2,5\% de glutaraldeído em $0,1 \mathrm{M}$ de tampão cacodilato de sódio $(\mathrm{pH} 7,2)$. Em seguida, foram centrifugadas por 10 minutos, $14000 \mathrm{rpm}$ e incubadas a $4{ }^{\circ} \mathrm{C}$, durante a noite. $\mathrm{O}$ "pellet" celular foi lavado e pós-fixado com 1\% de tetróxido de ósmio e 10,5\% de sacarose, e incubado a temperatura ambiente por 2 horas. A amostra foi lavada com solução de $0,5 \%$ de acetado de uranila e $10,5 \%$ de sacarose, e incubada a temperatura ambiente, durante a noite. Após este período, foi desidratada com etanol gelado em concentrações crescentes. Foi realizada incubação por 10 minutos e reproduzida esta etapa por mais 3 vezes. O etanol absoluto foi substituído por óxido de propileno $(100 \%)$, incubado por 10 minutos e repetida essa etapa novamente.

A etapa de infiltração foi iniciada com óxido de propileno/resina "spurr" (1:1, EMS). No qual o "pellet” foi incubado por 6 horas, em agitação leve e constante. Logo após este período, a solução foi retirada e adicionado resina "spurr" (100\%, EMS) e incubado durante a noite. Após esse período o material foi incubado à $75{ }^{\circ} \mathrm{C}$ por aproximadamente 42 horas (para polimerização da resina).

Em seguida, foi feito cortes $(0,5 \mu \mathrm{m}$ de espessura) e estes, corados com $1 \%$ de azul de toluidina em solução $1 \%$ de borato de sódio, para serem observados em microscópico de luz. O bloco com o "pellet" de células foi cortado (em secções ultrafinas) com lâmina de diamante própria para amostras analisadas em MET, e colocadas em tela de níquel (CF100-ni, EMS). O contraste foi realizado com 1\% de acetado de uranila, incubado a temperatura ambiente, por 5 minutos. Em seguida, a tela foi lavada com PBS e armazenada a temperatura ambiente, durante a noite. E então foi realizada a análise em microscópio eletrônico de transmissão JEOL 1010 (Jeol Inc., Peabody, MA, USA), em $80 \mathrm{kV}$.

\subsubsection{Análise por MEV}

Após a adesão das células mamárias $\left(10^{5}\right.$ células $)$ em lamínulas $(13 \mathrm{~mm})$ por 24 horas, as células foram lavadas com PBS $1 \mathrm{X}$ e fixadas com $2 \%$ de glutaraldeído em tampão 0,1 M de cacodilato de sódio ( $\mathrm{pH} 7,2$ ), por 2 horas. As células foram lavadas e pós-fixadas com $1 \%$ de tetróxido de ósmio e 10,5\% de sacarose, e incubado a 
temperatura ambiente por 1 hora. Após, a amostra foi desidratada com etanol gelado em concentrações crescentes. Foi realizada incubações por 3 minutos, sendo que com o etanol absoluto foi reproduzida esta etapa por mais 3 vezes. As amostras foram secas em aparelho de ponto crítico (CPD-030 Critical Point Dryer, Bal Tec, Liechtenstein) e em seguida, foram montadas em bases metálicas ("stubs") utilizando uma camada de esmalte e cobertas com íons de ouro em aparelho (SCD-040, Bal Tec). E então foi realizada a análise em microscópio eletrônico de varredura (MEV - JEOL JSM-7401F FESEM, Tóquio, Japão) da Central Analítica do Instituto de Química - USP, em 5.0 kV.

\subsubsection{Análise e quantificação de vesículas extracelulares usando NanoSight}

Para análise utilizando o NanoSight, o meio condicionado de fibroblastos não tumorais e células tumorais de mama (MCF-7 e MDA-MB-231) passou pelas mesmas etapas mencionadas para isolamento de vesículas extracelulares, no entanto, não foi adicionado inibidor de protease. E o "pellet" foi ressuspendido em PBS 1X e congelado imediatamente à $-80{ }^{\circ} \mathrm{C}$.

Com o aparelho NanoSight LM10 ('Nanoparticle Tracking Analysis' - NTA, Amesbury, Reino Unido) é possível visualizar e analisar partículas do meio condicionado de células. Para a análise, o meio condicionado foi centrifugado conforme descrito anteriormente e o "pellet” ressuspenso em $1 \mathrm{ml}$ de PBS $1 \mathrm{X}$ estéril. Em seguida, a amostra foi colocada na câmara da unidade de análise do aparelho. A câmara da amostra possui $500 \mu \mathrm{m}$ de profundidade, mas a profundidade do feixe é de cerca de 20 $\mu \mathrm{m}$, no ponto de análise, a condizer com a profundidade do foco do sistema óptico de imagem.

Este aparelho é acoplado a uma câmara CCD (“charge-coupled device") e um laser emitindo um feixe de 60-mW com comprimento de onda à $405 \mathrm{~nm}$. As aquisições foram realizadas por 60 segundos, com uma taxa de 30 frames por segundo, e o movimento de partículas analisado por software NTA (NanoSight). O software foi otimizado para identificar e acompanhar cada partícula em uma base e monitorar o seu movimento browniano, quadro a quadro. A velocidade do movimento de partículas foi utilizada para calcular o tamanho da mesma. Essa análise foi feita em colaboração com o laboratório da Profa. Dra. Vilma Martins e Dr. Marcos V. S. Dias (International Research. A. C. Camargo Cancer Center). 


\subsubsection{Análise proteômica}

Com o intuito de analisar a composição proteica das vesículas extracelulares isoladas, realizamos ensaio de proteômica em colaboração com os laboratórios da Profa. Dra. Solange Serrano (Instituto Butantan) e do Prof. Dr. André Zelanis (UNIFESP).

Primeiramente, foi realizada a digestão tripsínica em solução de vesículas extracelulares isoladas de células tumorais de mama MDA-MB-231. Para cada amostra biológica, um volume contendo $100 \mu \mathrm{g}$ de proteínas foi submetido ao procedimento de digestão tripsínica em solução conforme descrito por Kleifeld e colaboradores (KLEIFELD et al., 2011). Inicialmente, à mistura proteica foi adicionada uma solução de hidrocloreto de guanidina ( $\mathrm{GuHCl}$; preparada em água MilliQ $\left.{ }^{\circledR}\right)$ para uma concentração final de $4 \mathrm{M} \mathrm{GuHCl}$. Em seguida, foi adicionada uma solução de ditiotreitol (DTT; preparada em água MilliQ ${ }^{\circledR}$ ) para uma concentração final de $5 \mathrm{mM}$ DTT e a mistura foi incubada a $65{ }^{\circ} \mathrm{C}$, por 1 hora. Após este período, a mistura foi mantida a temperatura ambiente, por 5 minutos e depois, uma solução de iodoacetamida (IAA; preparada em água MilliQ ${ }^{\circledR}$ ) foi adicionada para uma concentração final de 15 mM IAA e a mistura foi mantida no escuro, a temperatura ambiente, por 1 hora. $\mathrm{O}$ excesso de IAA foi consumido pela adição de uma solução de DTT para uma concentração final de $15 \mathrm{mM}$ DTT e a mistura mantida a temperatura ambiente, por 15 minutos.

A remoção dos reagentes utilizados na etapa de desnaturação $(\mathrm{GuHCl})$, redução de pontes dissulfeto (DTT) e alquilação de sulfidrilas livres (IAA) foi realizada pela precipitação das proteínas com 8 volumes de acetona gelada e 1 volume de metanol gelado e subsequente incubação da mistura a $-80{ }^{\circ} \mathrm{C}$, por 3 horas. Ao término deste período, o material foi centrifugado a $14.000 \mathrm{~g}, 4{ }^{\circ} \mathrm{C}$, por 10 minutos, o sobrenadante foi descartado e o "pellet" protéico lavado com 1 volume de metanol gelado. A mistura foi novamente centrifugada e o "pellet" protéico lavado com 1 volume de metanol gelado. O sobrenadante foi descartado e os microtubos contendo o precipitado protéico foram mantidos abertos, a temperatura ambiente, para secar. Os precipitados foram solubilizados para uma concentração final de $1 \mu \mathrm{g} / \mu \mathrm{l}$ pela adição sequencial das seguintes soluções: $5 \mu \mathrm{l}$ de $5 \mathrm{mM} \mathrm{NaOH}$ (preparado fresco), $85 \mu 1$ de água MilliQ ${ }^{\circledR}$ e 10 $\mu l$ de 500 mM HEPES. O pH final da solução foi aferido e ajustado (com $1 \mathrm{~N} \mathrm{HCl}$ ou $100 \mathrm{mM} \mathrm{NaOH}$ ) para 7,5, conforme o caso. Foi retirado um volume correspondente a 1 
$\mu \mathrm{g}$ de proteínas $(=1 \mu \mathrm{l})$, e esta amostra separada para aferir a eficiência da digestão tripsínica. Em seguida, foi adicionado um volume de uma solução de tripsina ("Proteomics grade", Sigma) preparada em $1 \mathrm{mM} \mathrm{HCl}$ para uma razão de 1:100 (enzima: substrato) e a mistura foi incubada a $37^{\circ} \mathrm{C}$, por 18 horas.

Após a incubação, um volume correspondente a $1 \mu \mathrm{g}$ de proteínas $(=1 \mu \mathrm{l})$ foi retirado e as amostras (de antes e depois da digestão tripsínica) foram aplicadas em gel de SDS-poliacrilamida a $12 \%$, sob condições redutoras. As bandas foram visualizadas através de coloração com nitrato de prata. Exceto pela banda correspondente à tripsina, a ausência de bandas protéicas nas amostras submetidas à digestão enzimática indicou eficiência no processo.

Para realizar o fracionamento de peptídeos foi feita a montagem de "StageTips" (C18, Thermo Fisher Scientific). Primeiramente a membrana C-18 (Octadecyl, C18bonded silica, $3 \mathrm{M}$ Empore Extraction Disks) foi colocada em uma placa de Petri limpa. Em seguida, foi feito um furo na membrana utilizando a agulha "blunt" (de uma seringa do tipo Hamilton ${ }^{\circledR}$ ) de forma a retirar um pedaço (em forma de círculo) da membrana. Após, colocar a agulha dentro de uma ponteira de $1000 \mu \mathrm{l}$, o pedaço de membrana preso à agulha foi empurrado utilizando o êmbolo da seringa plástica descartável $\left(\right.$ Hamilton $^{\mathrm{TM}}$ ). Certificando que o pedaço da membrana estava localizado no final da ponteira.

A amostra foi acidificada para uma concentração final de 0,5\% de TFA - ácido trifluoroacético (o $\mathrm{pH}$ da amostra deve estar entre 1 e 2.5). Para todas as etapas seguintes, a amostra foi aplicada em cima da "StageTip" (o volume deve fluir de cima para baixo). Sem inverter a "StageTip", a seringa plástica de $20 \mathrm{ml}$ foi acoplada e posicionado o êmbolo desta, de forma a usar o ar no interior da seringa. A "StageTip" foi bem presa à seringa de forma que ela não se solte quando for aplicada a pressão. Pressão foi aplicada de forma a fazer com que a solução da amostra passasse pelas membranas da "StageTip". Em seguida, as amostras foram aplicadas a $300 \mu 1 / \mathrm{min}$, mas as etapas de eluição foram realizadas em fluxo mais lento (10 a $30 \mu \mathrm{l} / \mathrm{min}$ ).

Para o condicionamento da amostra na "StageTip", a membrana da mesma foi hidratada com um volume de metanol. Pressão foi aplicada de forma a fazer com que o solvente atravesse a membrana. O solvente foi descartado. Foi aplicado $50 \mu 1$ de "Buffer B” (1\% de TFA (vol/vol) e 80\% de ACN - acetonitrila (vol/vol), sendo $2 \mathrm{ml}$ de água MilliQ ${ }^{\circledR}, 8 \mathrm{ml}$ de ACN e $100 \mu \mathrm{l}$ HOAc - ácido acético). Sendo que o "flowthrough" foi 
descartado. Em seguida foi aplicado $100 \mu \mathrm{lde}$ "Buffer A" (1\% de HOAc (vol/vol) e 5\% de $\mathrm{ACN}$ (vol/vol), sendo 9,5 ml de água MilliQ ${ }^{\circledR}, 0,5 \mathrm{ml}$ de $\mathrm{ACN}$ e $100 \mu \mathrm{L}$ de HOAc); e o "flowthrough" foi descartado.

A amostra foi aplicada na "StageTip" e, em seguida, aplicado $100 \mu 1$ do "Buffer A" e descartado o "flowthrough". "StageTip" foi lavada novamente com "Buffer A" e descartado o "flowthrough". Então, a amostra foi eluída com $100 \mu 1$ de "Buffer B" e foi coletada em tubo novo. Em seguida, a amostra foi concentrada usando sistema à vácuo (“SpeedVac"), até um volume de aproximadamente 1 a $2 \mu \mathrm{l}$. Foram adicionados 5 a 10 $\mu \mathrm{lde}$ "Buffer A" e as amostras foram analisadas diretamente ou mantidas a $-80{ }^{\circ} \mathrm{C}$ para uso posterior.

As análises de cromatografia líquida acoplada à espectrometria de massas sequencial (LC-MS/MS) foram realizadas utilizando um espectrômetro de alta resolução "Ion Trap-Orbitrap" (LTQ-Orbitrap Velos, Thermo Scientific) do Laboratório Especial de Toxinologia Aplicada, Instituto Butantan. O espectrômetro é acoplado a um sistema de cromatografia líquida de fluxo manométrico (Accela Pump, Thermo Scientific) usando um fluxo de $400 \mathrm{~nL} /$ minutos. Os dados foram analisados utilizando o software MaxQuant (Max Planck Institute of Biochemistry, Martinsried, Alemanha).

\subsection{Efeitos da depleção de AHNAK em células tumorais}

A proteína AHNAK foi identificada em amostras de vesículas isoladas de células MDA-MB-231. Então, decidimos silenciar a proteína AHNAK e verificar seu papel na formação das vesículas.

Células MDA-MB-231 foram transfectadas usando AHNAK-siRNA ("small interfering RNA" - siRNA, Santa Cruz Biotechnology Inc., Santa Cruz, CA, USA) levando à diminuição da expressão do RNA mensageiro e consequentemente da proteína AHNAK nessas células. siRNA foi obtido comercialmente, bem como o siRNA-controle, o meio de transfecção (Opti-MEM, Gibco ${ }$, Life Technologies) e o reagente de transfecção formador de lipossomos (Lipofectamine 2000, Life Technologies).

As células foram cultivadas em placas de 6 poços a $70 \%$ de confluência, em meio DMEM suplementado com 10\% de SFB, isento de antibiótico. Em seguida, de acordo com as instruções do fabricante, o meio de transfecção, o reagente de transfecção e o 
siRNA $(10 \mu \mathrm{M})$ foram combinados, de modo que a concentração final do siRNAAHNAK e o siRNA-controle fosse $50 \mathrm{nM}$, e incubados a temperatura ambiente por 30 minutos. Essa solução foi adicionada às células, que permaneceram a $37^{\circ} \mathrm{C}$ por 48 horas. Como controle, outro grupo de células foi transfectado com RNA de sequência "scrambled" que não induz degradação de nenhuma mensagem celular. A eficiência da transfecção foi analisada por imunofluorescência e por "immunoblot”, visando detectar se o tratamento com siRNA diminuiu a expressão da proteína em questão.

Células transfectadas foram usadas em ensaio de co-cultura, conforme mencionado anteriormente, e a presença, bem como, a troca de vesículas pelas células foi avaliada. Estas células também foram usadas nos demais ensaios celulares (viabilidade, proliferação, migração e invasão), o meio condicionado dessas células foi analisado pelo NanoSight, além de que as células também foram visualizadas por MET e MEV.

\subsection{Ensaio de viabilidade celular}

Para avaliar a viabilidade celular, após silenciamento da proteína AHNAK, células MDA-MB-231 transfectadas ou não (controle) foram plaqueadas em placa de 24 poços, na concentração de $10^{5}$ células. Após 24 horas, o meio foi substituído por meio isento de SFB e incubadas por adicionais 24 horas. Em seguida, foram tripsinizadas e quantificadas utilizando método por exclusão de corante azul de Trypan (1:10, Sigma). Este corante de alto peso molecular não atravessa membranas celulares íntegras de células vivas, e como células mortas apresentam membranas rompidas, o corante penetra nas células, corando em azul as células mortas.

Células azuis (mortas), bem como as células totais foram quantificadas para calcular a porcentagem de células viáveis.

\subsection{Imunofluorescência}

A proteína AHNAK foi identificada em amostras de proteínas totais. A imunofluorescência foi realizada para analisar a distribuição de AHNAK em células MDA-MB-231, MCF-7 e nos fibroblastos não tumorais, cultivados em monocamada. 
Estudamos também a imunolocalização de AHNAK em células de câncer de mama com expressão reduzida desta molécula (células MDA-MB-231 AHNAK-siRNA).

Fibroblastos não tumorais também foram co-cultivados com células tumorais de mama MDA-MB-231 sobre lamínulas de vidro, na concentração de 2,5 x10 4 células (cada linhagem). Estas células foram coradas (fibroblastos em verde e MDA-MB-231 em vermelho) e seguido protocolo de co-cultura, conforme descrito anteriormente.

As células foram fixadas com 4\% de PFA em PBS 1X (10 min), a membrana foi permeabilizada com 0,5\% de triton X-100 em PBS (10 minutos, Sigma); as lamínulas foram lavadas com $0,05 \%$ de "tween-20" em PBS e foi feito bloqueio com $10 \%$ de soro de cabra (KPL, Gaithersburg, USA) por 1 hora. Em seguida, as lamínulas foram lavadas e incubadas com anticorpo primário $\operatorname{AHNAK}$ (1:50, E5, camundongo, sc390743 (Santa Cruz Biotechnology Inc., Santa Cruz, CA, USA) por 1 hora. As lamínulas foram lavadas novamente por 3 vezes de 5 minutos com 0,05\% de "tween-20" em PBS, e incubadas com anticorpo secundário Alexa Fluor ${ }^{\circledR} 568$ ou 647 "goat anti-mouse IgG" (Life Technologies), no qual foi diluído em $10 \%$ de soro de cabra na concentração de 1:400, e incubado por 1 hora, no escuro. As lamínulas foram novamente lavadas com PBS 1X (10 vezes), 0,05\% de “tween-20” em PBS (10 vezes) e com água milliQ. Em seguida, foi realizada a evidenciação nuclear usando "ProLong" com "DAPI" (Life Technologies). A substituição do anticorpo primário por PBS foi utilizado como controle negativo.

Os resultados foram analisados em microscópio de fluorescência Axiophot (Carl Zeiss, Oberkochen, Alemanha), utilizando objetiva PlanApo de 100x (abertura numérica $=1.45)$. As imagens das células foram adquiridas com $\mathrm{o}$ auxílio de câmera monocromática CCD digital de alta sensibilidade, específica para amostras fluorescentes (CoolSnap HQ2, Photometrics Inc, Tucson, AZ, USA). O microscópio e demais equipamentos foram controlados pelo software "Metamorph Premier" 7.6 (Molecular Devices, Sunnyvale, CA, USA). As amostras também foram analisadas em microscópio confocal Leica TCS AOBS SP8 "Tandem Scanner" com sistema de detecção Leica SP Detector TM (Leica Microsystems, Alemanha) e também usando o microscópio confocal Zeiss LSM 780 NLO (CEFAP-ICB), controlado pelo software ZEN 2011. 


\subsection{Ensaio de proliferação celular}

Analisamos se as vesículas isoladas a partir de células MDA-MB-231 causariam efeitos sobre as células não tumorais de mama (fibroblastos e MCF-10A) e de células tumorais de mama (MCF-7 e MDA-MB-231). Foi realizada a análise da proliferação de cada linha celular separadamente, usando o método de incorporação de 5-bromo-2'desoxiuridina (BrdU). O efeito das vesículas isoladas sobre a proliferação de células MDA-MB-231 AHNAK-siRNA também foi investigada.

A incorporação ocorre durante a síntese do DNA de células que se encontram em processo de proliferação. BrdU é um nucleosídeo (nucleotídeo sem grupamento fostato) sintético, análogo da timidina, que é incorporado no DNA recém-sintetizado de células durante a fase $\mathrm{S}$ do ciclo celular (LEHNER et al., 2011).

As células de mama $\left(2.5 \times 10^{4}\right.$ células $)$ foram cultivadas a $37^{\circ} \mathrm{C}$ em atmosfera contendo $5 \%$ de $\mathrm{CO}_{2}$, por 24 horas. As células foram lavadas com DMEM sem SFB e incubadas em mesmo meio acrescido de $60 \mu \mathrm{M}$ BrdU (Sigma Chemical Co, St. Louis, MO, USA) e então, cultivadas por adicionais 24 horas. Vesículas isoladas de células MDA-MB-231 (4, 20 ou $40 \mu \mathrm{g} / \mathrm{ml})$ foram adicionadas ao meio com BrdU de células em monocultura. Para amostras controle, foi usado apenas meio sem SFB com BrdU. Meio com $10 \%$ de SFB foi usado como controle positivo de proliferação.

Após este período, as células foram fixadas com 4\% de PFA em PBS 1X. Em seguida, as células tiveram o DNA desnaturado com $2 \mathrm{~N}$ de $\mathrm{HCl}$ por 30 minutos. Esta etapa de desnaturação do DNA auxilia na ligação do anticorpo primário ao BrdU previamente incorporado. Após este período, o $\mathrm{HCl}$ foi removido e as células foram incubadas com tampão borato $\left(0,1 \mathrm{M} \mathrm{H}_{3} \mathrm{BO}_{3} ; 0,15 \mathrm{M} \mathrm{NaOH}\right.$; $\left.\mathrm{pH} 8,4\right)$ por 10 minutos. Este foi removido e as células incubadas com 0,3\% de Triton X-100 em PBS, por 15 minutos. Os sítios inespecíficos foram bloqueadas com 1\% de BSA (Sigma) e 0,1\% de Triton X-100 em PBS, por 1 hora. Após, foram lavadas com PBS e incubadas com anticorpo primário anti-BrdU biotinilado ("Biotin mouse", 1:100, MAB 3262B Millipore Billerica, MA, USA), durante a noite. As células foram lavadas e incubadas com anticorpo secundário Alexa Fluor ${ }^{\circledR} 555$ “streptavidin” (1:500, Life Technologies), por 1 hora. Então, as células foram novamente lavadas com $0,05 \%$ de "tween-20" em PBS e montadas com "ProLong” com "DAPI" (Life Technologies). 
As imagens foram feitas a partir de pelo menos quatro campos microscópicos por meio de microscópio de fluorescência (Axio vert A1, Carl Zeiss) usando objetiva LDPlan de 20x (abertura numérica $=0.4)$. As imagens das células foram adquiridas com o auxílio de câmera digital AxioCam MRc (Carl Zeiss) e analisadas usando ImageJ (software de domínio público desenvolvido por Wayne Rasband, NIMH, NIH, Bethesda, MD, EUA, http://rsbweb.nih.gov/ij/). A percentagem de núcleos positivos para BrdU a partir do número total de núcleos (DAPI) foi calculada.

\section{8 "Immunoblot"}

"Immunoblots" foram realizados para comparar os níveis da proteína AHNAK entre lisados totais de células MDA-MB-231 e as suas vesículas isoladas; lisados de fibroblastos não tumorais e células MCF-7. E também para comparar amostras de lisados totais de células MDA-MB-231 e MDA-MB-231 AHNAK si-RNA.

Para observar a ativação das vias de sinalização ERK1/2 ("extracellular signalregulated kinase") e Akt ou PKB ("Protein kinase B”), células MCF-7 foram tratadas ou não, durante 30 minutos, 2 horas ou 24 horas com vesículas isoladas a partir de células MDA-MB-231 $(40 \mu \mathrm{g} / \mathrm{ml})$. Para o controle negativo e positivo, meio sem SFB e com $10 \%$ de SFB foi utilizado, respectivamente.

O lisado celular total foi obtido com tampão RIPA (150 mM NaCl, 1,0\% NP-40, $0,5 \%$ de desoxicolato, $0,1 \%$ de dodecilsulfato de sódio (SDS), $50 \mathrm{mM}$ Tris $\mathrm{pH} 8,0$ ) contendo coquetel de inibidores de protease (Sigma). Após centrifugação (10.000 g) durante 10 minutos a $4{ }^{\circ} \mathrm{C}$, os sobrenadantes foram recuperados e quantificados através do método de BCA (Pierce Inc Rockford, IL, USA). As vesículas foram isoladas conforme já descrito, adicionado tampão RIPA, centrifugadas e quantificadas. As amostras foram ressuspensas em tampão Laemmli contendo $62,5 \mathrm{mM}$ de Tris- $\mathrm{HCl}(\mathrm{pH}$ $6,8), 2 \%$ de SDS, $10 \%$ de glicerol, $5 \%$ de mercaptoetanol e $0,001 \%$ de azul de bromofenol.

A eletroforese foi realizada seguindo o método SDS-PAGE. Quantidades iguais $(20 \mu \mathrm{g})$ dos lisados celulares e das vesículas foram sujeitas a eletroforese em gel de $10 \%$ de poliacrilamida (preparado com 1,5 M Tris-HCl, 10\% SDS, 30\% bis-acrilamida, 10\% de persulfato de amônia e TEMED) ou gel 4-15\% (Mini-Protean ${ }^{\circledR}$, Bio-Rad, CA, USA). Após a eletroforese, as proteínas foram transferidas para membranas de 
nitrocelulose Hybond ECL (Amersham, GE Healthcare) e bloqueadas com 5\% de leite em TBS-tween-20 (TTBS) ou bloqueados com 5\% BSA em TTBS, durante a noite a 4 ${ }^{\circ} \mathrm{C}$. As membranas foram incubadas com anticorpos contra: AHNAK (1:1000, H-153, coelho, sc-98373, Santa Cruz Biotechnology); Akt e phospho-Akt (1:1000, coelho, Cell Signalling Technology, MA, USA); Erk 1/2 (1:1000, coelho, Santa Cruz Biotechnology) e phospho-Erk 1/2 (1:1000, camundongo, Santa Cruz Biotechnology). Esses anticorpos primários foram detectados por anticorpos secundários conjugados com peroxidase.

O protocolo de quimioluminescência foi utilizado para revelar a reação (ECL kit, Amersham), e esta foi observada no equipamento MF-ChemiBIS 3.2 ("DNR BioImaging Systems", Biocompare). Para remover os anticorpos primários e secundários, possibilitando a marcação com outro anticorpo primário, as membranas foram submetidas ao processo de "stripping" utilizando o reagente "Restore Western Blot Stripping Buffer" (Pierce) e submetidas a novas marcações. Como controle positivo, o anticorpo primário $\beta$-actina (1:2000, camundongo, Sigma) foi utilizado, a fim de confirmar se a quantidade de proteína carregada no gel foi equivalente em todas as amostras.

\subsection{Ensaio de invasão e migração celular}

Para avaliar se células se o "knockdown" de AHNAK em células MDA-MB-231 influenciaria a capacidade migratória e invasiva dessas células, foi utilizado o sistema de câmaras bipartites do tipo "Transwell” separadas por membrana de policarbonato com poros de $8 \mu \mathrm{m}$ de diâmetro (BD Biosciences), usando placa de 12 poços (Corning). A câmara superior foi coberta por membrana basal reconstituída (Cultrex ${ }^{\circledR}, R \& D$ Systems), pelo qual foi diluído 1:1 usando meio DMEM-F12 sem SFB e polimerizado sobre a membrana da câmara, a $37{ }^{\circ} \mathrm{C}$ por 30 minutos. As células MDA-MB-231 (controle e transfectadas com AHNAK-siRNA), após 3 horas em meio sem SFB, foram tripsinizadas e ressuspendidas em número de $10^{5}$ células/ml em meio DMEM-F12 sem SFB para cada poço. As células foram colocadas na câmara superior de migração. Dessa forma, tivemos células sobre a membrana porosa coberta por matriz. Na câmara inferior foi adicionado meio DMEM-F12 com $10 \%$ de SFB e incubada por 48 horas a $37^{\circ} \mathrm{C}$ na 
estufa de $\mathrm{CO}_{2}$ para que ocorra a digestão da matriz e invasão das células da câmara superior para inferior.

Após o período de incubação, a câmara superior de invasão foi delicadamente invertida, para remoção do conteúdo (células que não invadiram e meio de cultura) da câmara superior. Nessa situação restaram somente as células que digeriram a matriz e migraram, ficando localizadas na face inferior da membrana. Essas células foram fixadas em 4\% de PFA em PBS, coradas com solução de 0,2\% de Cristal violeta em $20 \%$ de metanol. As células na parte superior do filtro foram removidas com um cotonete. Imagens das células invasoras, no lado inferior do filtro, foram feitas de sete campos de cada membrana utilizando câmara acoplada ao microscópio, deste modo, foi feita a quantificação do número de células que invadiram.

Para avaliar se células MDA-MB-231 AHNAK-siRNA ainda migrariam foi utilizado o sistema de câmaras bipartites do tipo "Transwell". Este ensaio foi realizado conforme ensaio de invasão, no entanto sem o uso da barreira de matriz, e incubado por 24 horas a $37{ }^{\circ} \mathrm{C}$, para que ocorresse a migração das células da câmara superior para inferior. Após este período, as células foram fixadas, coradas, fotografadas e quantificadas. Cada experimento também foi realizado pelo menos 3 vezes, em triplicata.

\subsection{Análise da expressão da proteína AHNAK através de imuno-histoquímica (IHQ)}

Lâminas de "tissue microarray" contendo amostras normais e tumorais de mama humana foram obtidas da Imgenex (San Diego, CA; IMH-364). Cortes (4 $\mu \mathrm{m})$ de 59 amostras foram analisadas, incluindo 35 casos de carcinoma ductal invasivo (CDI), 1 caso de carcinoma sarcomatóide, 1 caso de carcinoma papilífero intra-ductal, 1 caso de carcinoma medular atípico, 1 caso de carcinoma metaplástico, 1 caso de carcinoma ductal in situ, 10 casos de metástase tumoral e 9 amostras de tecido mamário normal adjacente ao tecido canceroso.

Os cortes foram desparafinados em xileno e hidratados em concentrações decrescentes de etanol. A recuperação de antígenos foi realizada com tampão citrato (10 $\mathrm{mM}$ ácido cítrico, $0,05 \%$ de "Tween-20", $\mathrm{pH} 6,0)$ em autoclave $\left(121{ }^{\circ} \mathrm{C}\right)$ durante 2 minutos. Os cortes foram bloqueados durante 1 hora com 1\% de BSA (Sigma) em PBS. AHNAK foi identificada com anticorpo policlonal de coelho (1:100 em PBS, 
HPA026643, Sigma) durante a noite a $4{ }^{\circ} \mathrm{C}$. O bloqueio da peroxidase endógena foi realizada durante 20 minutos, seguido do anticorpo secundário conjugado com biotinaanti-coelho (Dako) durante 30 minutos. Diaminobenzidina (Sigma) foi utilizado como cromogênio e os cortes foram contrastados com hematoxilina de Mayer (Sigma). Análise de imunomarcação de AHNAK foi realizada. Imagens de campo claro de cinco imagens selecionadas aleatoriamente a partir de cada amostra foram adquiridas utilizando um microscópio Primostar (Carl Zeiss) equipado com uma câmera CCD (AxiocCam HRc, Carl Zeiss). Todas as imagens foram obtidas com a mesma ampliação (40x). Áreas de coloração diaminobenzidina foram segmentadas utilizando a deconvolução da cor através de "plug-in" do software ImageJ. Após a segmentação dos canais das imagens, a porcentagem de área marcada para AHNAK foi obtida.

\subsection{Análise estatística}

Foram realizados três ensaios independentes e cada ensaio foi feito em triplicata. Os dados obtidos foram analisados usando o software Graph Pad Prism 5 (Graph Pad Software, Inc., San Diego, CA, EUA). O Teste t de Student foi usado para avaliar as diferenças entre dois grupos. As diferenças entre três ou mais grupos foram avaliadas por análise de variância ("One-way" ou "Two-way" ANOVA), seguido por testes de comparações múltiplas. As diferenças foram consideradas estatisticamente significativas quando $\mathrm{p} \leq 0,05$. 


\section{RESULTADOS}

\subsection{Troca de vesículas a partir de células tumorais de mama e fibroblastos não tumorais em co-cultura}

Os ensaios de co-cultura foram realizados utilizando os fibroblastos não-tumorais e células tumorais de mama (MDA-MB-231 ou MCF-7).

Projeções ortogonais a partir de secções ópticas confocal mostrou a troca de vesículas a partir de células tumorais de mama (vermelho) e fibroblastos não tumorais adjacentes (verde), bem como a interação das duas linhagens (Figuras 9A-B, setas). A quantificação de vesículas mostrou um aumento de vesículas a partir de células tumorais doadas para fibroblastos não tumorais. Além disso, é evidente que a células MDA-MB231 estimulou maior produção de vesículas por fibroblastos em comparação com células MCF-7 (Figura 9C). 


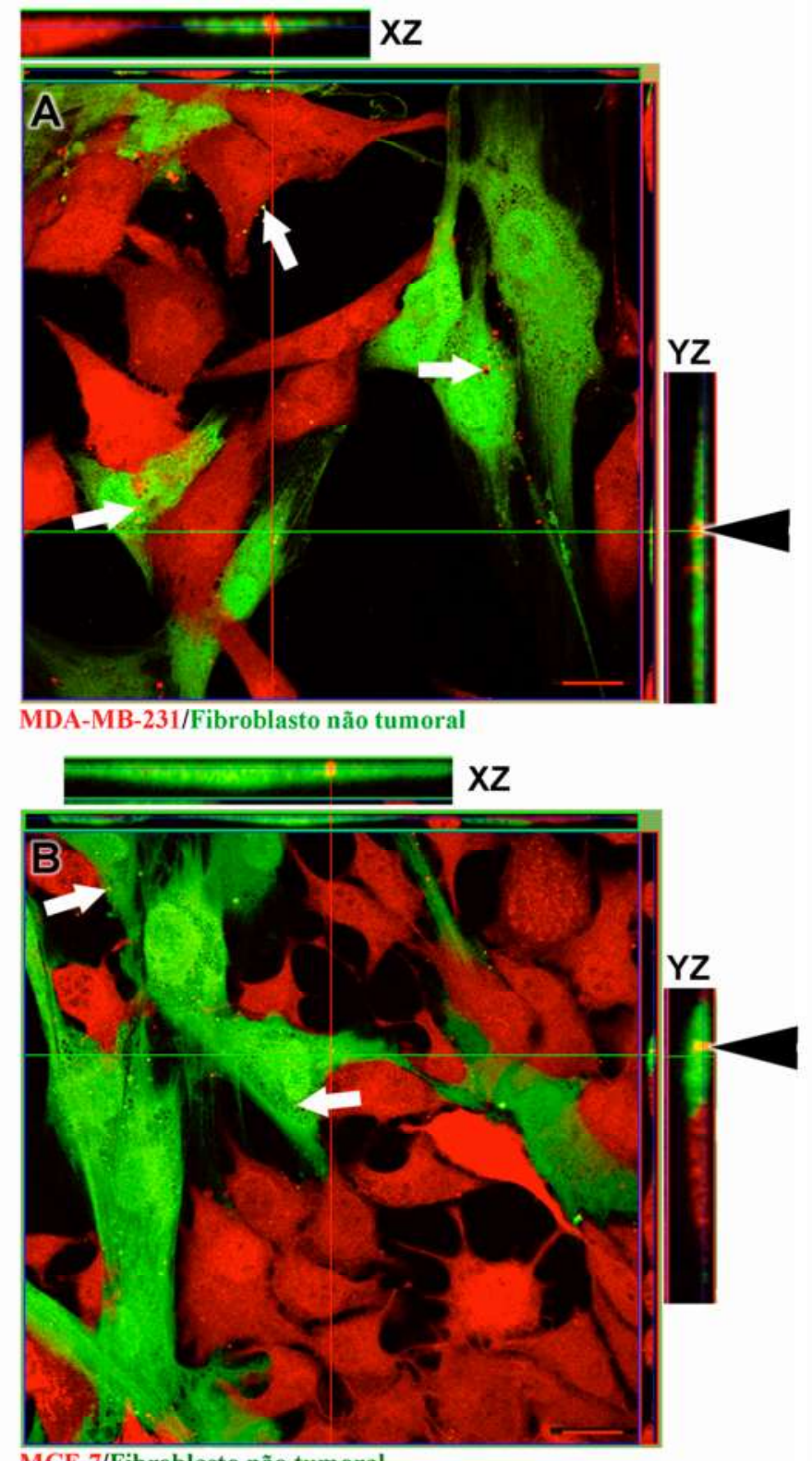

MCF-7/Fibroblasto não tumoral

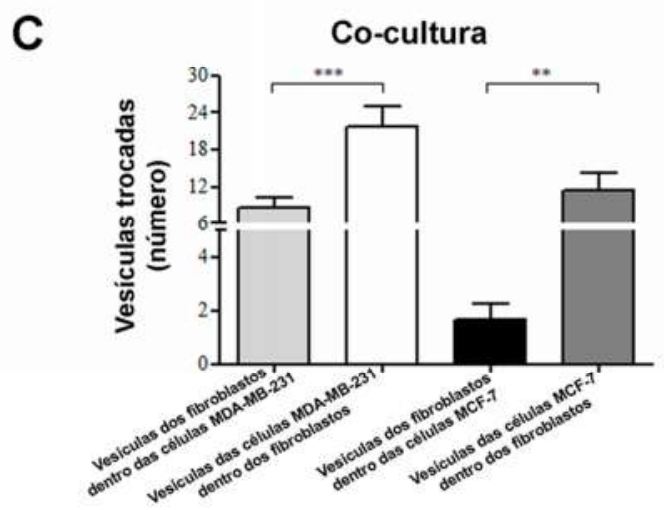

Figura 9 - Troca de vesículas entre as células tumorais de mama e fibroblastos não tumorais. 
Figura 9 - Troca de vesículas entre as células tumorais de mama e fibroblastos não tumorais. (A e B) Imagens do microscópio confocal mostram fibroblastos (verde) e células MDA-MB-231 ou MCF-7 (vermelho). As imagens mostram a troca de estruturas vesiculares entre as células comprovada através das vesículas vermelhas dentro das células verdes e viceversa (setas). (C) A quantificação de vesículas mostra o número de vesículas a partir dos fibroblastos doadas para as células MDA-MB-231, a partir da célula MDA-MB-231 para os fibroblastos, a partir dos fibroblastos para as células MCF-7 e das células MCF-7 para os fibroblastos. One-way ANOVA com pós-teste Bonferroni mostra diferença estatisticamente significativa entre células MDA-MB-231 e fibroblastos (***, $\mathrm{p}<0,0001)$ e entre células MCF-7 e fibroblastos $(* *, p<0,001)$. Os dados em $C$ representam média \pm erro da média de 20 células, em pelo menos cinco ensaios independentes. Escala: $20 \mu \mathrm{m}$.

\subsection{Estruturas vesiculares e protrusões celulares em MET e MEV}

Através de MET foi possível a visualização de protrusões das células cultivadas em monocultura, que podem ser responsáveis por originar as microvesículas (Figuras 10A-C, cabeças de seta). Os fibroblastos exibiram vesículas revestidas por membrana de densidade e tamanho homogêneos com aproximadamente $200 \mathrm{~nm}$ de diâmetro e de maneira geral mostraram menos protrusões em comparação com células tumorais (Figura 10A). As células MCF-7 apresentaram vesículas extracelulares de tamanhos variados e com densidade distinta (Figura 10B). As células MDA-MB-231 apresentam um número maior de protrusões de membrana plasmática e podem ser observadas vesículas extracelulares com diferentes diâmetros. As vesículas extracelulares observadas nas linhagens estudadas são revestidas de membrana, com um diâmetro que varia de 100 a $400 \mathrm{~nm}$ (Figuras 10A-C, setas).

Vesículas isoladas de células tumorais de mama MDA-MB-231 também foram analisadas por MET. Após o isolamento de vesículas a partir do meio condicionado, foi possível observar estruturas heterogêneas liberadas pelas células, com diferentes densidades eletrônicas e diâmetro variando entre 100 a 700 nm (Figura 10D).

Além disso, também foi possível a visualização de protrusões celulares (Figura 10 E-G, cabeça de seta), bem como, de estruturas vesiculares (Figuras 10E-H, setas), dentro e fora das células cultivadas em monocultura através de MEV. 

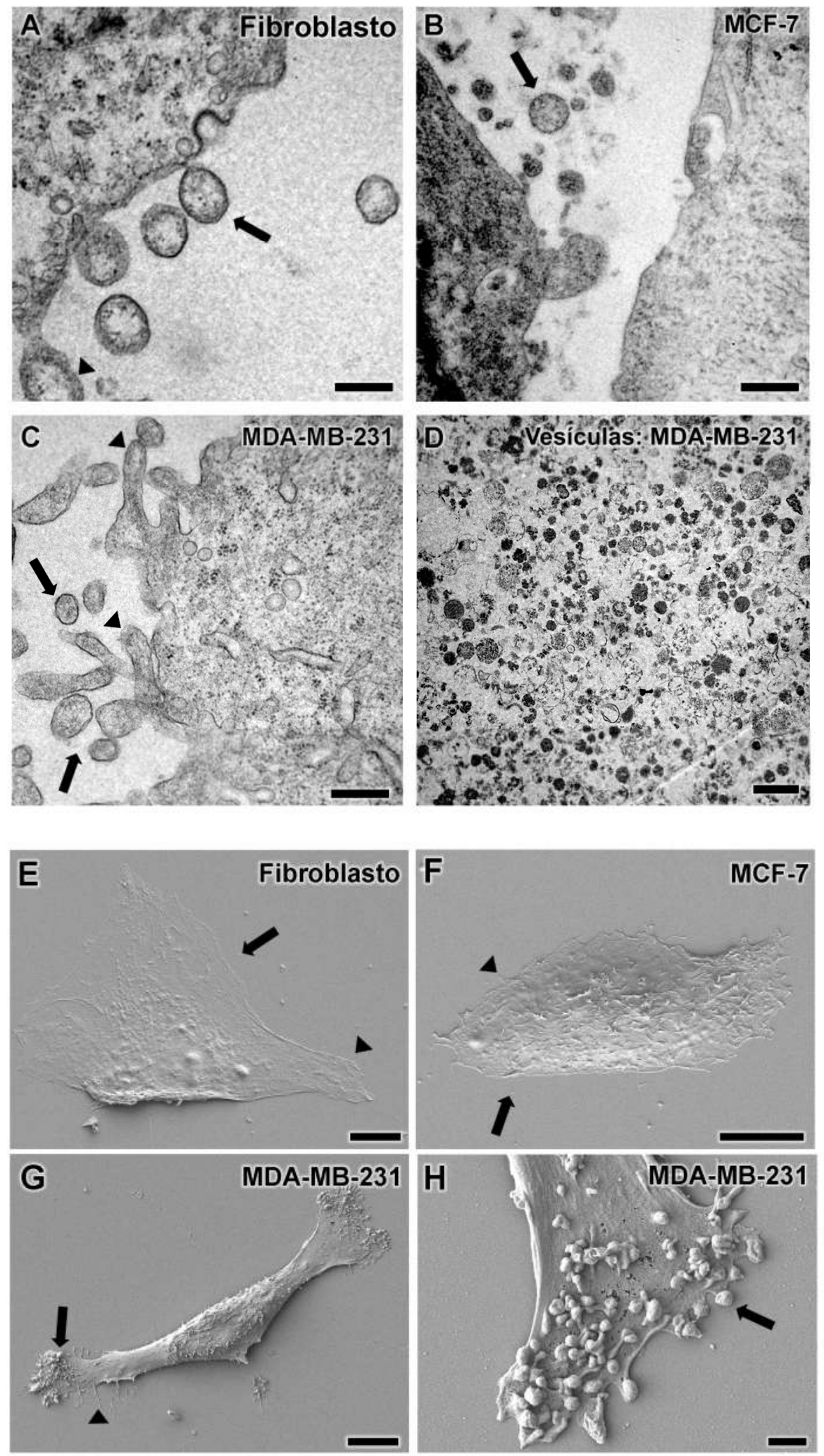

Figura 10 - Células tumorais apresentam mais protrusões de membrana plasmática e vesículas extracelulares quando comparados com fibroblastos não tumorais. 
Figura 10 - Células tumorais apresentam mais protrusões de membrana plasmática e vesículas extracelulares quando comparados com fibroblastos não tumorais. Análise por microscopia eletrônica de transmissão de (A) fibroblastos, (B) células MCF-7 e (C) células MDA-MB-231 mostrando estruturas vesiculares isoladas e circulares como tamanho de aproximadamente 100 a $400 \mathrm{~nm}$ (setas). E também protrusões celulares que podem tornar-se microvesículas (cabeça de seta), principalmente em células MDA-MB-231 (C, setas). (D) Imagem de MET das vesículas extracelulares liberadas pelas células MDA-MB-231, como uma população heterogênea com diferentes diâmetros e densidade eletrônica. Com a microscopia eletrônica de varredura de (E) fibroblastos, (F) células MCF-7 e (G-H) células MDA-MB-231 foi possível visualizar as protrusões celulares (cabeça de seta) e vesículas (setas) na superfície de células MDA-MB-231. A média do tamanho das vesículas é de aproximadamente $200 \mathrm{~nm}$ de diâmetro. Escala: $200 \mathrm{~nm}(\mathrm{~A}-\mathrm{C})$ e $500 \mathrm{~nm}(\mathrm{D})$, na MET; $10 \mu \mathrm{m}(\mathrm{E}-\mathrm{G})$ e $1 \mu \mathrm{m}(\mathrm{H})$, na MEV.

\subsection{Análise e quantificação de estruturas vesiculares mostraram alta concentração de vesículas extracelulares das células tumorais de mama MDA-MB-231}

Verificou-se o pelo equipamento NanoSight, número e tamanho de vesículas extracelulares isoladas a partir do meio condicionado de fibroblastos, células MCF-7 e MDA-MB-231. Maior concentração de partículas/ml totais foi encontrada em amostras de células MDA-MB-231 em comparação com células MCF-7 e fibroblastos (Figura 11B). Vesículas maiores foram observadas com microscopia de luz (entre $500 \mathrm{~nm}$ e 1 $\mu \mathrm{m})$, no entanto, com a análise NanoSight, descobrimos que vesículas menores ( $>10$ nm) também estavam presentes nas amostras e que as células mais indiferenciadas possuem mais vesículas entre 10 e $110 \mathrm{~nm}$, compatível com o tamanho de exossomos do que as células MCF-7 e os fibroblastos não tumorais. Em relação às vesículas maiores (microvesículas) com diâmetros entre $120 \mathrm{~nm}$ e $690 \mathrm{~nm}$, observamos que as células MDA-MB-231 produzem três vezes mais vesículas que os fibroblastos não tumorais.

\subsection{Análise proteômica de estruturas vesiculares liberado pelas células tumorais MDA-MB-231}

Como a amostra de células MDA-MB-231 apresentou a maior concentração de vesículas, decidimos investigar o conteúdo dessas vesículas através de análise proteômica, onde foram identificadas diversas proteínas.

Consideramos as proteínas mais relevantes na nossa amostra de acordo com o maior número de peptídeos identificados, já que quanto maior número de peptídeos maior probabilidade da proteína pertencer a amostra. Exemplificamos algumas destas 
proteínas, e a escala de cor representa a abundância do peptídeo para cada uma delas (Figura 11C). A molécula AHNAK foi a proteína mais relevante identificada em vesículas isoladas de células MDA-MB-231; proteínas putativas de vesículas, como descritas em enlargeosomos também foram identificadas na amostra estudada, tal como Anexina A2, Anexina A6, myoferlin e S-100 (Figura 11C) e também em anexos. 
A

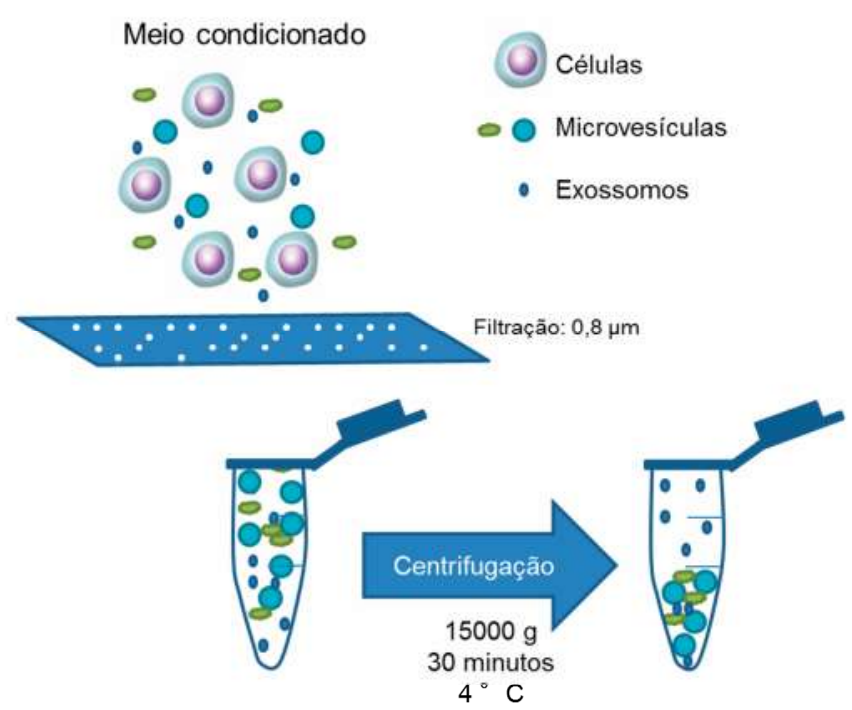

B

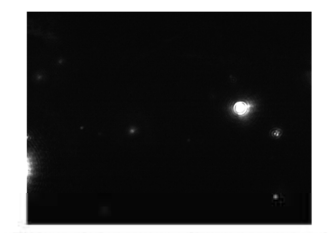

Fibroblasto não tumoral

NanoSight

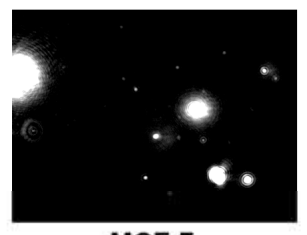

MCF-7

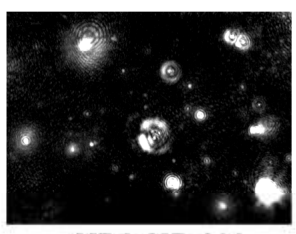

MDA-MB-231

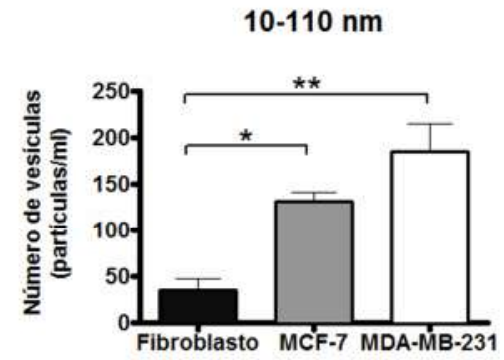

$10-110 \mathrm{~nm}$
$120-690 \mathrm{~nm}$

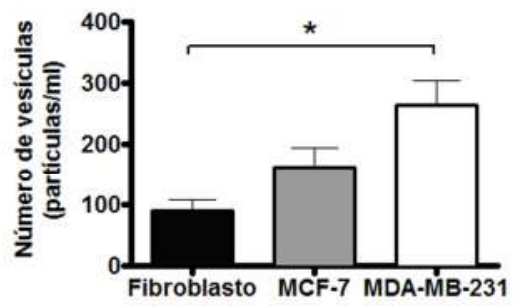

C

\begin{tabular}{|c|l|c|}
\cline { 2 - 3 } \multicolumn{1}{c|}{} & \multicolumn{1}{c|}{ Proteína } & Peptídeos \\
\hline 1 & Neuroblast differentiation-associated protein AHNAK & 21 \\
\hline 2 & Annexin A2;Annexin;Putative annexin A2-like protein & 13 \\
\hline 5 & Heat shock protein HSP 90-alpha & 8 \\
\hline 16 & Integrin beta-1 & 6 \\
\hline 20 & Myoferlin & 5 \\
\hline 22 & Annexin;Annexin A6 & 4 \\
\hline 131 & Caveolin;Caveolin-1;Caveolin-3 & 1 \\
\hline 204 & Protein S100-A10 & 1 \\
\hline
\end{tabular}

Figura 11 - Análise do número de partículas mostra maior número de vesículas liberadas pelas células tumorais MDA-MB-231 do que as células menos agressivas ou não tumorais. 
Figura 11 - Análise do número de partículas mostra maior número de vesículas liberadas pelas células tumorais MDA-MB-231 do que as células menos agressivas ou não tumorais. (A) Fluxograma sobre o protocolo de isolamento de vesículas. (B) Vesículas isoladas a partir de meio condicionado de células tumorais de mama e fibroblastos foram isoladas e analisadas por tamanho usando NanoSight. O gráfico mostra duas faixas (10 nm - $110 \mathrm{~nm}$ e $120 \mathrm{~nm}-690 \mathrm{~nm}$ ). Células MDA-MB-231 mostra significativamente mais partículas que os fibroblastos não tumorais. One-way ANOVA com pós-teste de Bonferroni mostra diferença estatisticamente significativa no número de partículas entre as três linhagens celulares $(* *, p=0,0048$; *, $\mathrm{p}=0,022 ; *, \mathrm{p}=0,017)$. Os dados em $\mathrm{B}$ representam média \pm erro da média de ensaios em triplicata. (C) O secretoma de vesículas isoladas de células MDA-MB-231 foi submetido a LCMS/MS. Tabela representativa das proteínas identificadas na análise proteômica. A escala de cor representa a abundância de peptídeos em cada proteína. AHNAK é a proteína mais abundante.

\subsection{As vesículas isoladas da linhagem celular MDA-MB-231 induzem a proliferação celular de MCF-7 por meio da ativação de ERK 1/2}

Ensaios de proliferação celular de células de tumorais da mama (MCF-7 ou MDA-MB-231) e de células não tumorais (fibroblastos ou células MCF-10A) foram avaliados utilizando o método de incorporação de BrdU, após incubação com vesículas isoladas a partir de células MDA-MB-231. Não houve efeito das vesículas isoladas em fibroblastos, células MCF-10A e MDA-MB-231, enquanto que as vesículas de MDAMB-231 estimularam a proliferação da linhagem celular MCF-7 (Figura 12A).

Além disso, "immunoblot" mostrou que células MCF-7 tratadas com vesículas isoladas de células MDA-MB-231 apresentaram um aumento na ativação da via de sinalização ERK 1/2, após 30 minutos e 2 horas de incubação, quando comparado com o controle negativo não tratado. Além disso, a ativação de ERK 1/2 também foi observada em células tratadas com SFB, sugerindo um efeito semelhante para as vesículas que induziram a proliferação de células MCF-7 (Figura 12B). 
A

\section{Proliferação}
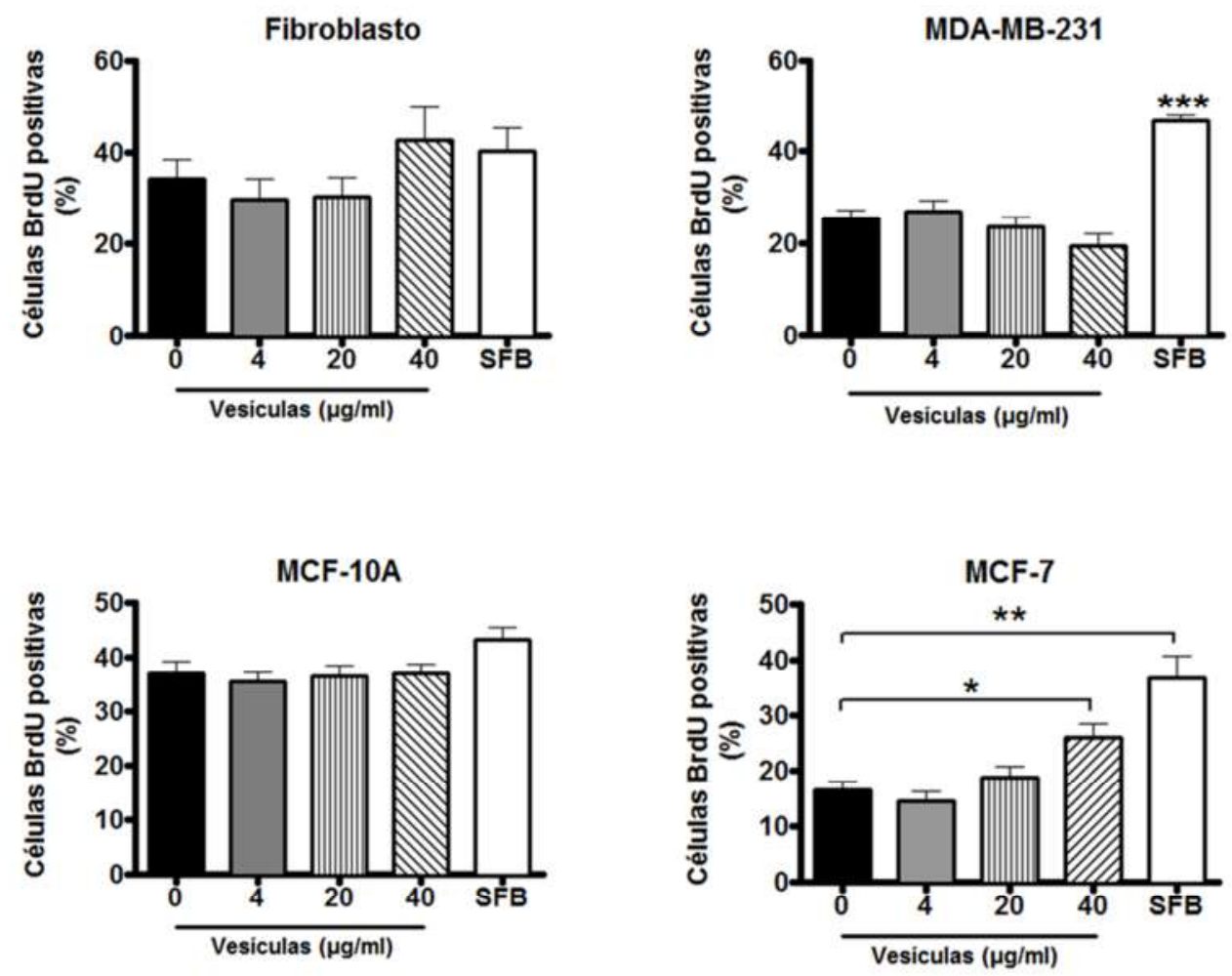

MCF-7

B

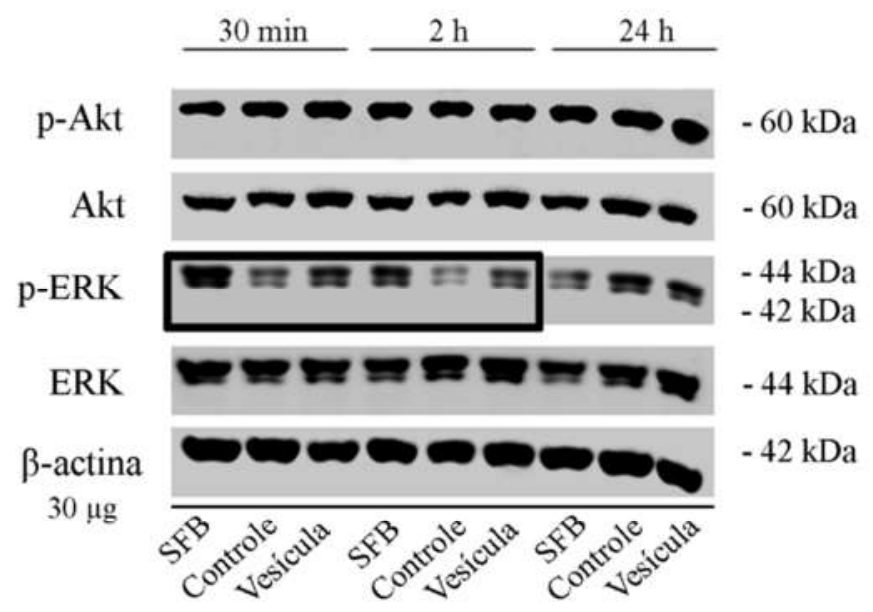

Figura 12 - Efeito das vesículas isoladas das células MDA-MB-231 na proliferação e ativação da sinalização. 
Figura 12 - Efeito das vesículas isoladas das células MDA-MB-231 na proliferação e ativação da sinalização. (A) As vesículas não tiveram efeito sobre a proliferação de fibroblastos não-tumoral, células MDA-MB-231 ou células MCF-10A. Por outro lado, as vesículas $(4,20$ ou $40 \mu \mathrm{g} / \mathrm{ml})$ isoladas a partir de células MDA-MB-231 e adicionados a (D) células MCF-7 induziram a proliferação quando analisada por ensaio de BrdU. Para o controle negativo, foi utilizado meio sem SFB. Meio com $10 \%$ de SFB foi utilizado como estímulo positivo. One-way ANOVA com pós-teste de Bonferroni mostra diferença estatisticamente significativa entre os grupos analisados MCF-7 (***, $p=0,0001)$. Os dados em D representam média \pm erro da média. (B) Expressão das proteínas ERK1/2 e Akt no lisado total de células MCF-7 tratadas ou não durante 30 minutos, 2 ou 24 horas com vesículas isoladas a partir de células MDA-MB-231 $(40 \mu \mathrm{g} / \mathrm{ml})$. Para o controle positivo e negativo, foi utilizado meio com $10 \%$ de SFB ou sem SFB, respectivamente.

\subsection{Imunolocalização de AHNAK}

A proteína AHNAK está distribuída no citoplasma (ao longo da membrana plasmática) e em vesículas das células tumorais da mama (Figuras 13A-B) e fibroblastos (Figura 13C). Em células MCF-7 (Figura 13B), AHNAK é encontrada localizada próximo das junções célula-célula. 


\section{A MDA-MB-231}
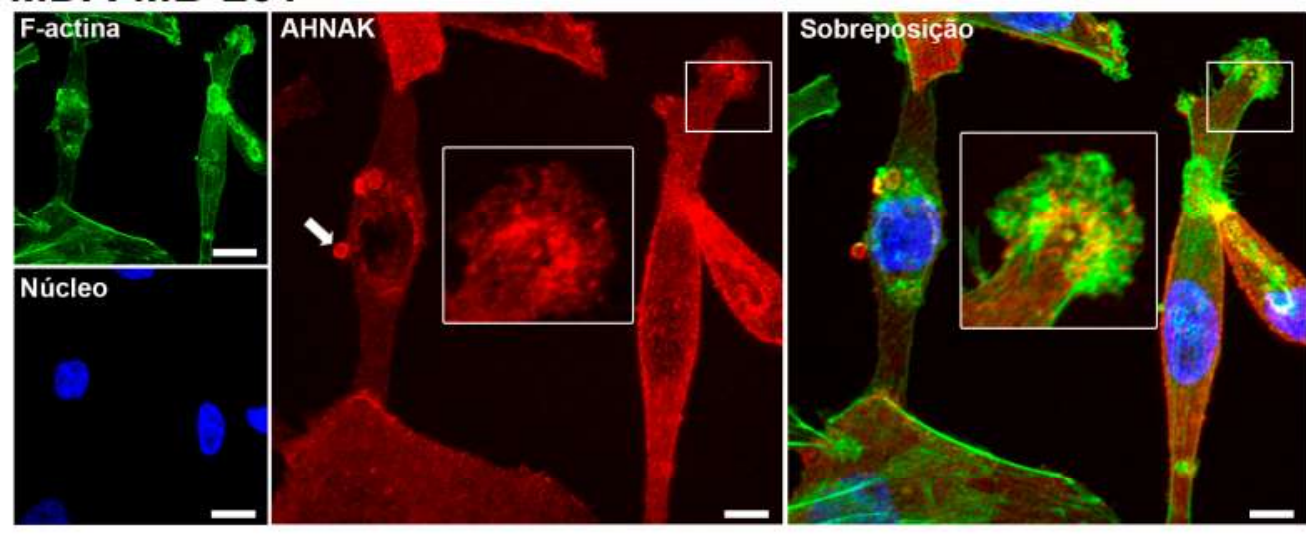

B MCF-7
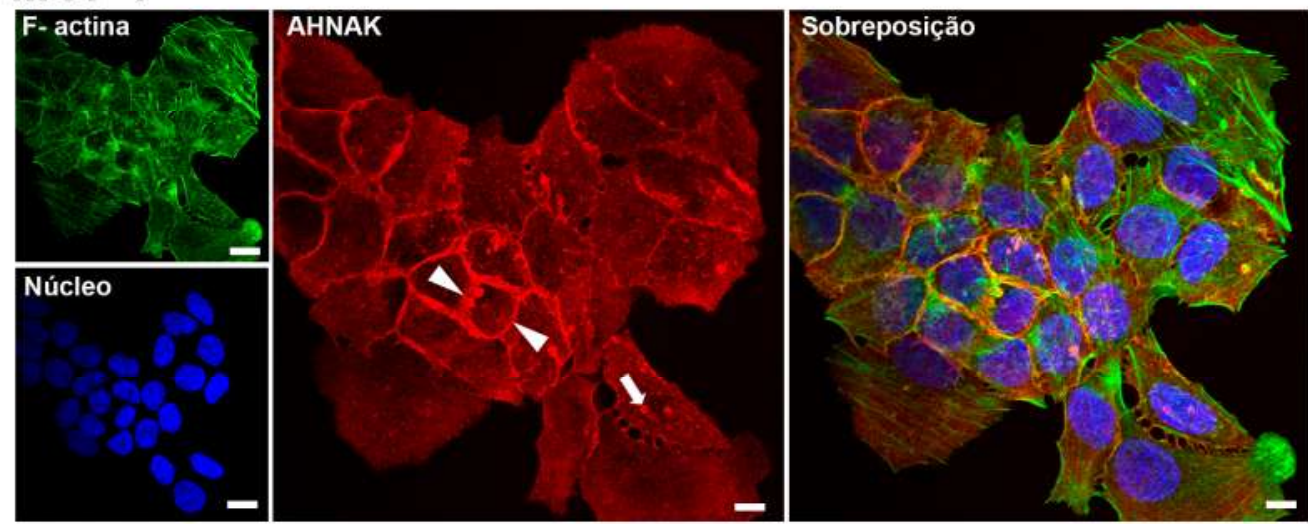

C Fibroblasto não tumoral
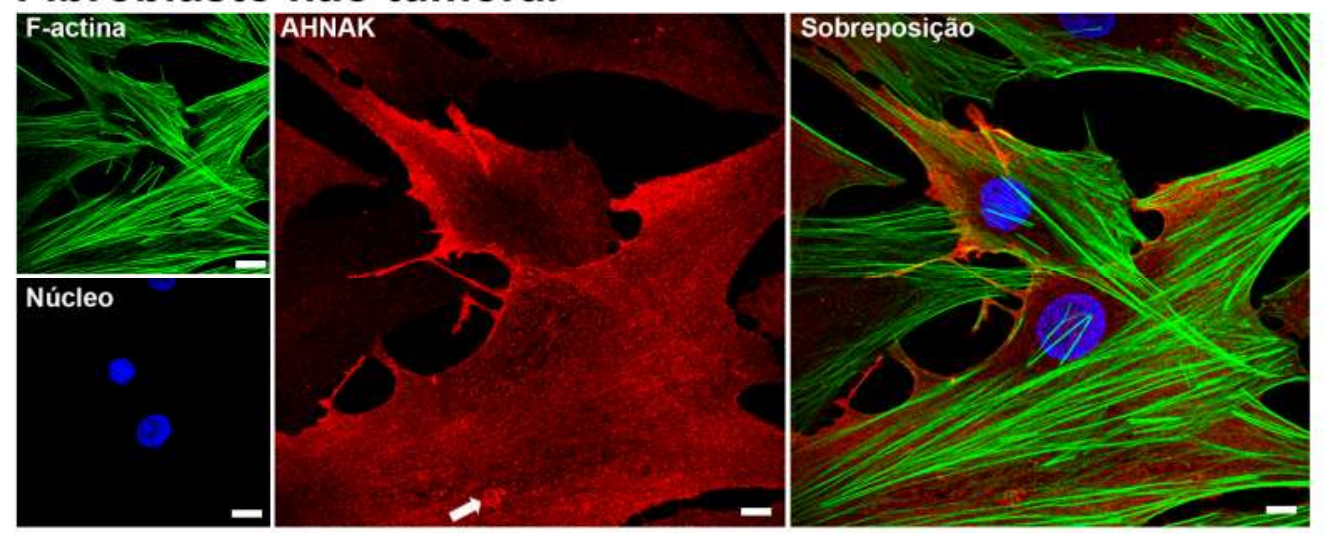

Figura 13 - AHNAK está localizada na membrana celular e em vesículas das células MDAMB-231. 
Figura 13 - AHNAK está localizada na membrana celular e em vesículas das células MDAMB-231. (A) Imunofluorescência de células MDA-MB-231 mostra a proteína AHNAK na membrana celular como estruturas pontuais (ver inserto na figura) e em vesículas liberadas (seta); (B) Em células MCF-7, AHNAK está localizada nas junções célula-célula (cabeça de seta) ou distribuída na membrana celular, mas também presente em vesículas (seta); (C) Nos fibroblastos não tumorais, a proteína AHNAK também está presente na borda da célula e na membrana celular (como pequenos pontos, por todo citoplasma): AHNAK (vermelho), actina (verde), núcleo (azul). Escala: $5 \mu \mathrm{m}$.

\subsection{AHNAK está localizada na vesícula doada da célula tumoral MDA-MB-231 dentro do fibroblasto não tumoral}

No ensaio de co-cultura com fibroblastos não tumorais e células MDA-MB-231 (Figura 14), observamos a co-localização da vesícula vermelha advinda da célula MDAMB-231 e a proteína AHNAK, presente no fibroblasto, mostrando que AHNAK também está presente nas vesículas doadas das células MDA-MB-231 (Figura 14B).

Para determinar se AHNAK estava presente em células de tumorais de mama e em vesículas isoladas a partir de células MDA-MB-231, foi realizado "immunoblot" (Figura 14C). O ensaio mostrou que o anticorpo reconheceu a proteína AHNAK de lisados totais das células e nas vesículas isoladas. 

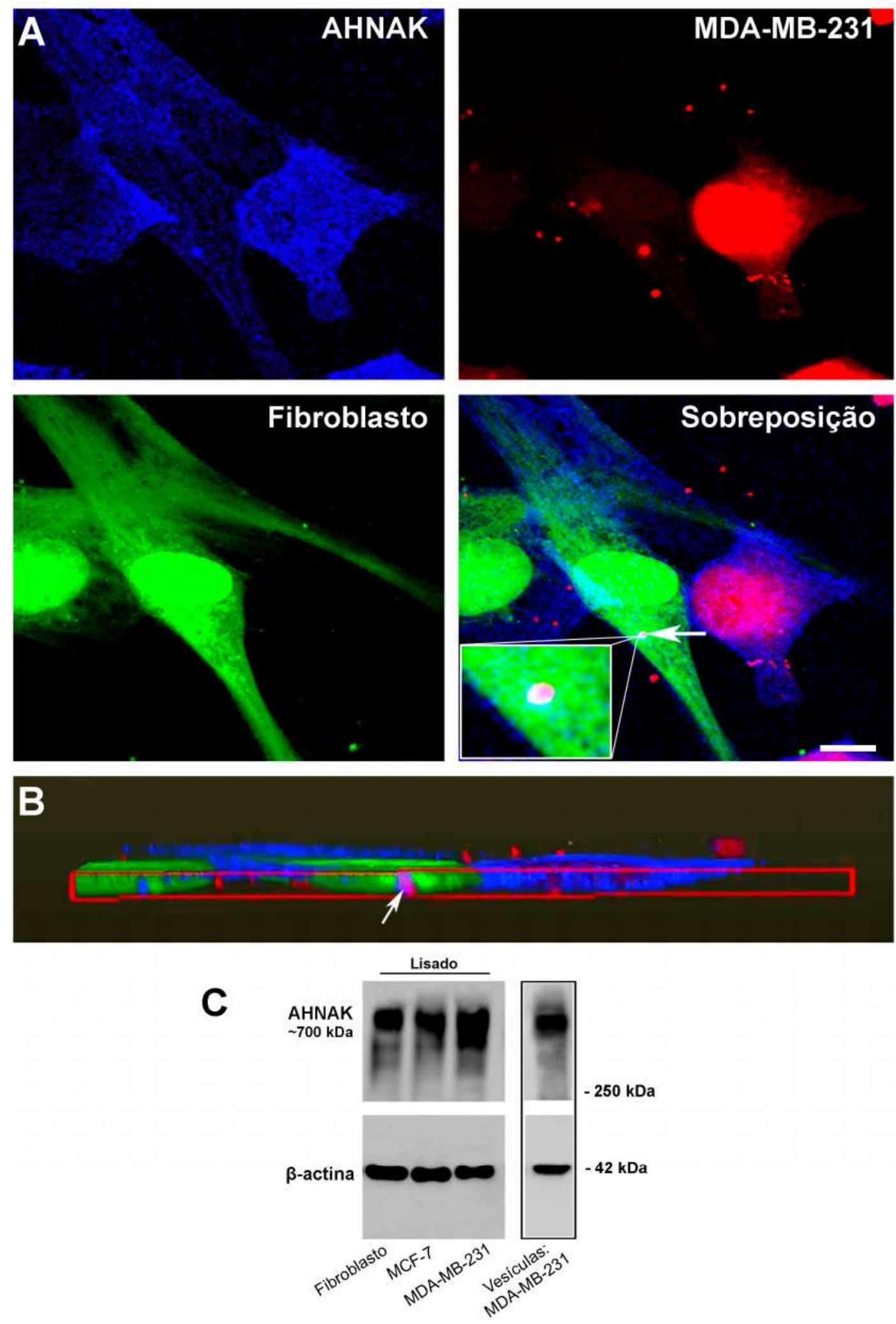

Figura 14 - AHNAK está localizada em vesícula doada da célula MDA-MB-231 para fibroblasto não tumoral. 
Figura 14 - AHNAK está localizada em vesícula doada da célula MDA-MB-231 para fibroblasto não tumoral. (A) Localização de AHNAK (azul) com vesícula da célula MDAMB-231 (vermelho) dentro do fibroblasto verde (seta, inserto) no ensaio de co-cultura. (B) Projeção 3D da vesícula no interior do fibroblasto (seta) a partir da Figura A. A vesícula magenta (derivada da célula MDA-MB-231 e contendo AHNAK) está localizado no interior do fibroblasto não tumoral (B, seta). (C) "Immunoblot" mostra os níveis de expressão da proteína AHNAK em lisado celular total (fibroblastos não tumorais, células MCF-7 e MDA-MB-231) e em vesículas isoladas a partir de células MDA-MB-231. Escala: $5 \mu \mathrm{m}$.

\subsection{AHNAK silenciada levou à diminuição do número de microvesículas e diminuiu as vesículas doadas para os fibroblastos não tumorais}

Investigamos os níveis de expressão da proteína AHNAK na linhagem celular MDA-MB-231 parental e na célula AHNAK silenciada por siRNA. A imunofluorescência e "immunoblot" ilustram a eficiência da proteína AHNAK silenciada (Figuras 15A).

Para analisar o papel putativo de AHNAK na troca de vesículas, ensaios de cocultura foram realizadas usando fibroblastos não tumorais e células MDA-MB-231 com AHNAK silenciada por siRNA. Foi realizado ensaio semelhante, como descrito anteriormente (Figura 9C) e observou um decréscimo no número de vesículas doadas a partir de células tumorais com níveis reduzidos AHNAK para os fibroblastos não tumorais, em comparação com células MDA-MB-231 transfectadas com siRNA "scrambled" (controle) (Figura 15B). O número de vesículas doadas pelos fibroblastos não tumorais para as células tumorais não foram afetados (Figura 15B).

Após silenciamento de AHNAK, também verificamos pelo NanoSight, o número e tamanho de vesículas extracelulares presente no meio condicionado de células MDAMB-231 silenciadas e células controle. As células apresentaram quantidade semelhante de vesículas que possuem tamanho compatível com exossomos, entre 10 e $110 \mathrm{~nm}$, no entanto, menor número de microvesículas $(120$ e $750 \mathrm{~nm})$ foi encontrado em amostra de células MDA-MB-231 AHNAK silenciadas, quando comparada com o controle (Figura $15 \mathrm{C})$. 
A
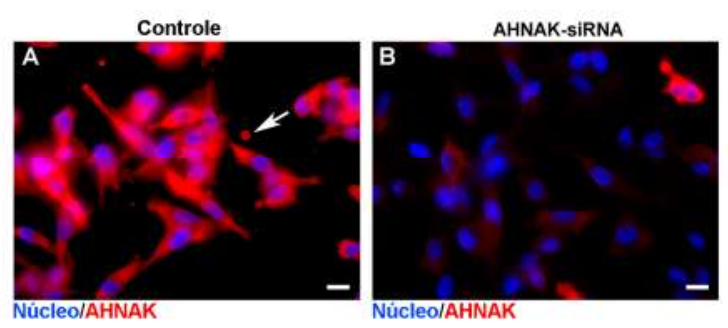

Núcleo/AHNAK
Eficiência da transfecção

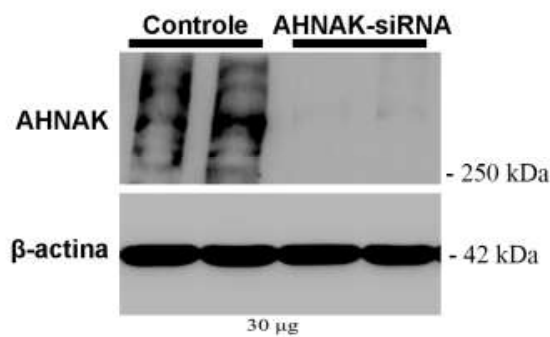

B

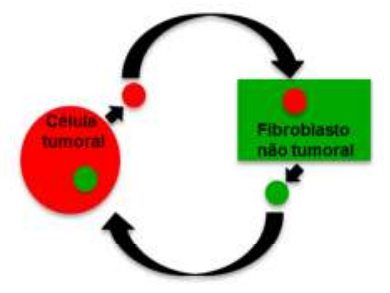

\section{Vesículas trocadas}

Co-cultura

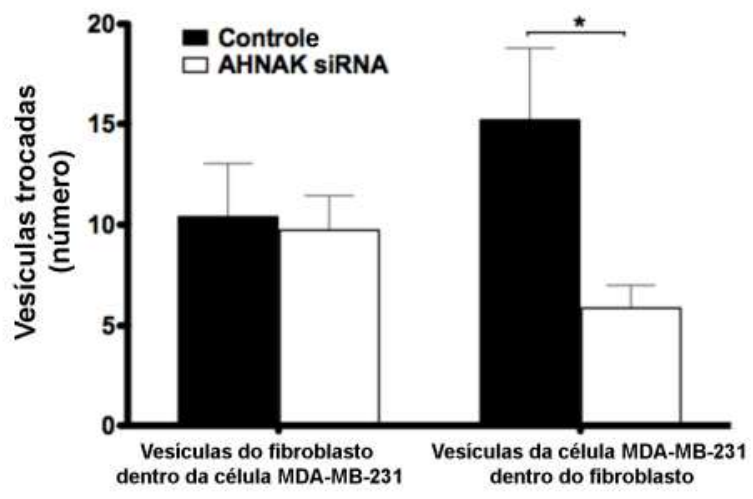

NanoSight
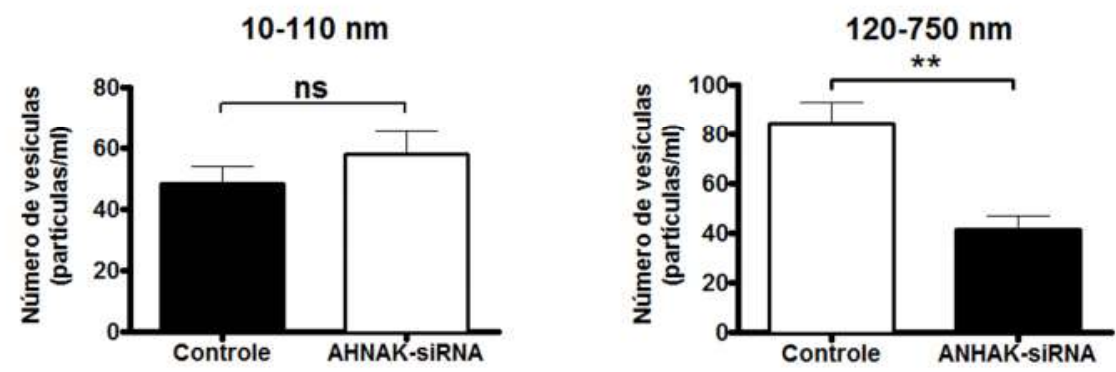

Figura 15 - Silenciamento de AHNAK inibe a formação e troca de microvesículas. 
Figura 15 - Silenciamento de AHNAK inibe a formação e troca de microvesículas. siRNA foi usado para silenciar a expressão de AHNAK em células MDA-MB-231. (A) Imunofluorescência e "immunoblot" confirmam a eficiência do silenciamento. Imunofluorescência de AHNAK em células MDA-MB-231 controle e em células AHNAK silenciadas. AHNAK está marcada com anti-mouse-Alexa-568 (vermelho) e os núcleos em DAPI (azul). Proteína AHNAK está distribuída nas células ao longo da membrana plasmática e em vesículas que foram detectadas (A, seta). "Immunoblot" mostra a expressão de AHNAK no lisado celular total de células MDA-MB-231 (controle e AHNAK-siRNA), $\beta$-actina como controle de carregamento. O tratamento com siRNA reduziu a expressão de AHNAK. Escala: 5 $\mu \mathrm{m}$. (B) A depleção de AHNAK diminuiu a transferência de vesículas a partir de células MDAMB-231 para fibroblastos. (C) As células com expressão reduzida desta molécula mostra diminuição significativa na formação de microvesículas. Resultados em B e C representam a média \pm erro da média de ensaios em triplicata. Os asteriscos indicam diferenças estatisticamente significativas $(* \mathrm{p}<0,05 ; * * \mathrm{p}<0,001)$. As células controle foram transfectadas com siRNA "scrambled".

\subsection{AHNAK silenciada promove a diminuição da migração e invasão celular}

Em seguida, foram analisados os efeitos de AHNAK sobre a migração, invasão e proliferação celular. AHNAK silenciada promoveu a diminuição da atividade migratória e invasiva das células MDA-MB-231 (Figuras 16A-B), mas não afetou a viabilidade e a proliferação celular (Figuras 16C-D). 

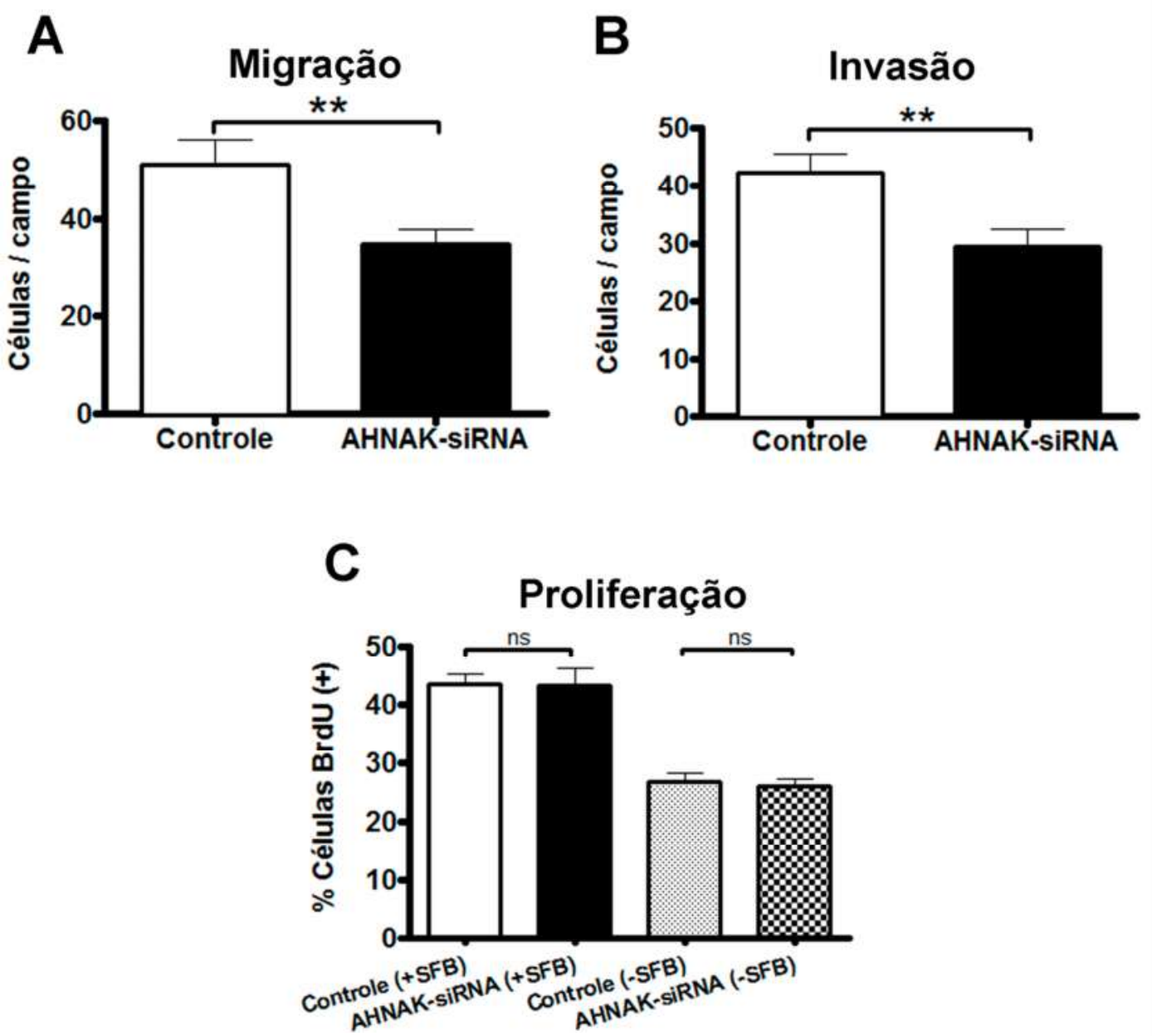

D
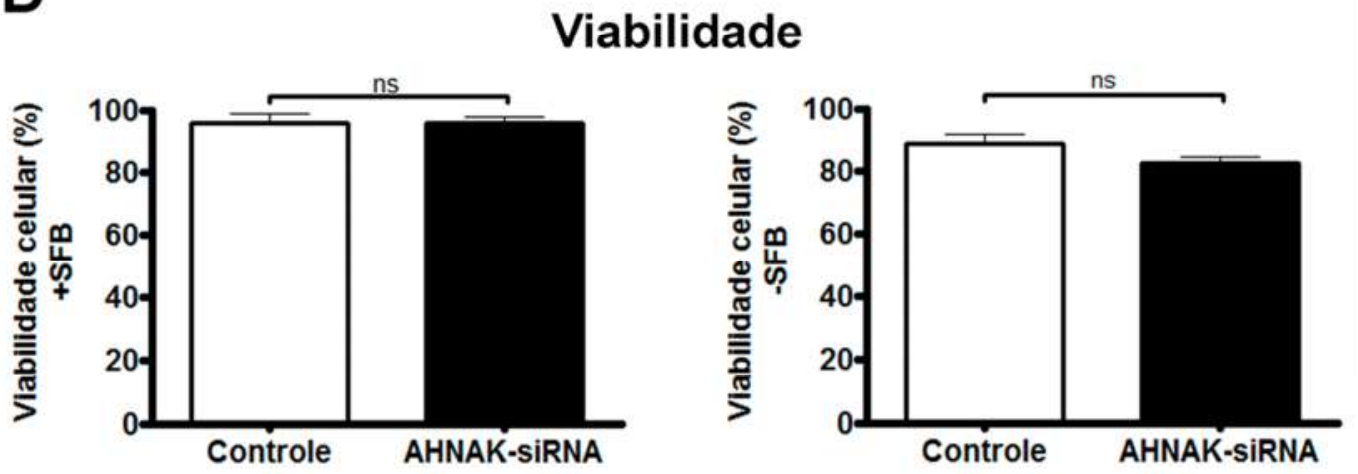

Figura 16 - Diminuição da migração e invasão celular foi estimulada pela diminuição da expressão de AHNAK. 
Figura 16 - Diminuição da migração e invasão celular foi estimulada pela diminuição da expressão de AHNAK. (A) AHNAK silenciada inibiu a atividade migratória das células MDAMB-231. Diminuição da migração de células MDA-MB-231 com o silenciamento de AHNAK por siRNA, quando comparada com células controle. (B) AHNAK silenciada inibiu a atividade invasiva de células MDA-MB-231. Houve diminuição da invasão de células MDA-MB-231 com o silenciamento de AHNAK por siRNA, quando comparada com células controle. (C, D) AHNAK silenciada não afetou a viabilidade celular e a proliferação das células na presença ou ausência de SFB. Os experimentos foram realizados em triplicata. Os dados em A e B representam média \pm erro da média. Os asteriscos indicam diferenças estatisticamente significativas $(* *, p=0,0078 ; * *, p=0,0059)$. As células controle foram transfectadas com siRNA "scrambled".

\subsection{Efeito de AHNAK no número de protrusões celulares e vesículas}

O papel de AHNAK na formação das protrusões celulares também foi observada através do MET utilizando células MDA-MB-231 com AHNAK silenciada por siRNA (Figuras 17A-B, setas). O número de protrusões das células diminuiu após o silenciamento de AHNAK, quando comparadas com células MDA-MB-231 transfectadas com siRNA "scrambled" (controle) (Figura 17G). Observou-se também, por meio de $\mathrm{MEV}$, a diminuição da produção de vesículas após AHNAK silenciada em células MDA-MB-231 (Figuras 17C-H). 

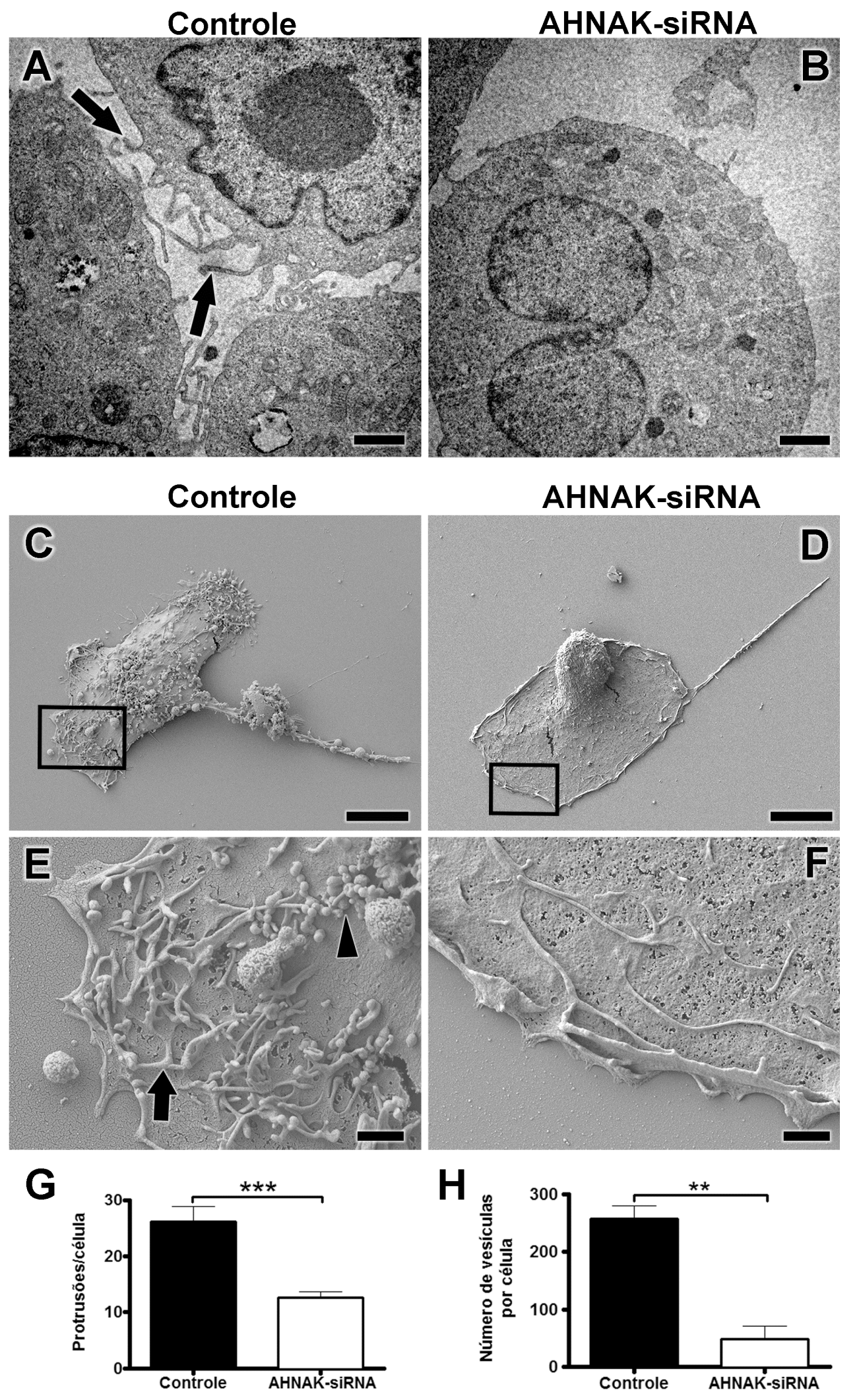

Figura 17 - O silenciamento da proteína AHNAK afetou o número de protrusões celulares e de vesículas das células MDA-MB-231. 
Figura 17 - O silenciamento da proteína AHNAK afetou o número de protrusões celulares e de vesículas das células MDA-MB-231. A microscopia eletrônica de transmissão mostra que o número de protrusões celulares (B) está diminuído em células MDA-MB-231 AHNAKsiRNA em comparação com o controle (A, seta). (C-F) Imagens de microscopia eletrônica de varredura de células MDA-MB-231, mostra vesículas na superfície das células (cabeça de seta). Depleção de AHNAK diminuiu a formação de vesículas em comparação com o controle (C e E, cabeça de seta). A depleção de AHNAK também induziu a menos protrusões $(D, F)$ em comparação aos controles (C e E, seta). (G) Quantificação através da MET confirma que a depleção AHNAK diminuiu significativamente as protrusões das células MDA-MB-231(teste $t$ de Student; ***, $\mathrm{p}=0,0001)$. (H) Há uma diminuição do número de vesículas em células MDAMB-231 AHNAK-siRNA em comparação com o controle (teste t de Student; **, $p=0,0028$ ). Os dados em $\mathrm{G}$ e $\mathrm{H}$ representam média \pm erro da média. Escala: $50 \mathrm{~nm}(\mathrm{~A}, \mathrm{~B}), 10 \mu \mathrm{m}(\mathrm{C}, \mathrm{D})$ e 1 $\mu \mathrm{m}(\mathrm{E}, \mathrm{F})$.

\subsection{Expressão de AHNAK é proeminente nos tumores da mama humano}

Foram avaliados os níveis de AHNAK em amostras de tecido mamário humano normal, tumoral e metástase em linfonodos através de IHQ (Figura 18A-C). No tecido mamário normal, apenas algumas células epiteliais foram marcadas com AHNAK (Figura 18A). Células tumorais mostraram a expressão de AHNAK nas regiões do citoplasma e membrana celular (Figura 18B). Células de carcinoma metastático, por sua vez, exibiram expressão de AHNAK mais marcante nas junções célula-célula (Figura 18C). A marcação para AHNAK não foi proeminente no estroma. Controle negativo sem reatividade (Figura 18D). Medidas das frações da área (\%) marcada com AHNAK demonstrou que tumores de mama e metástases tiveram expressão de AHNAK mais evidente do que o tecido mamário normal (Figura 18E). 

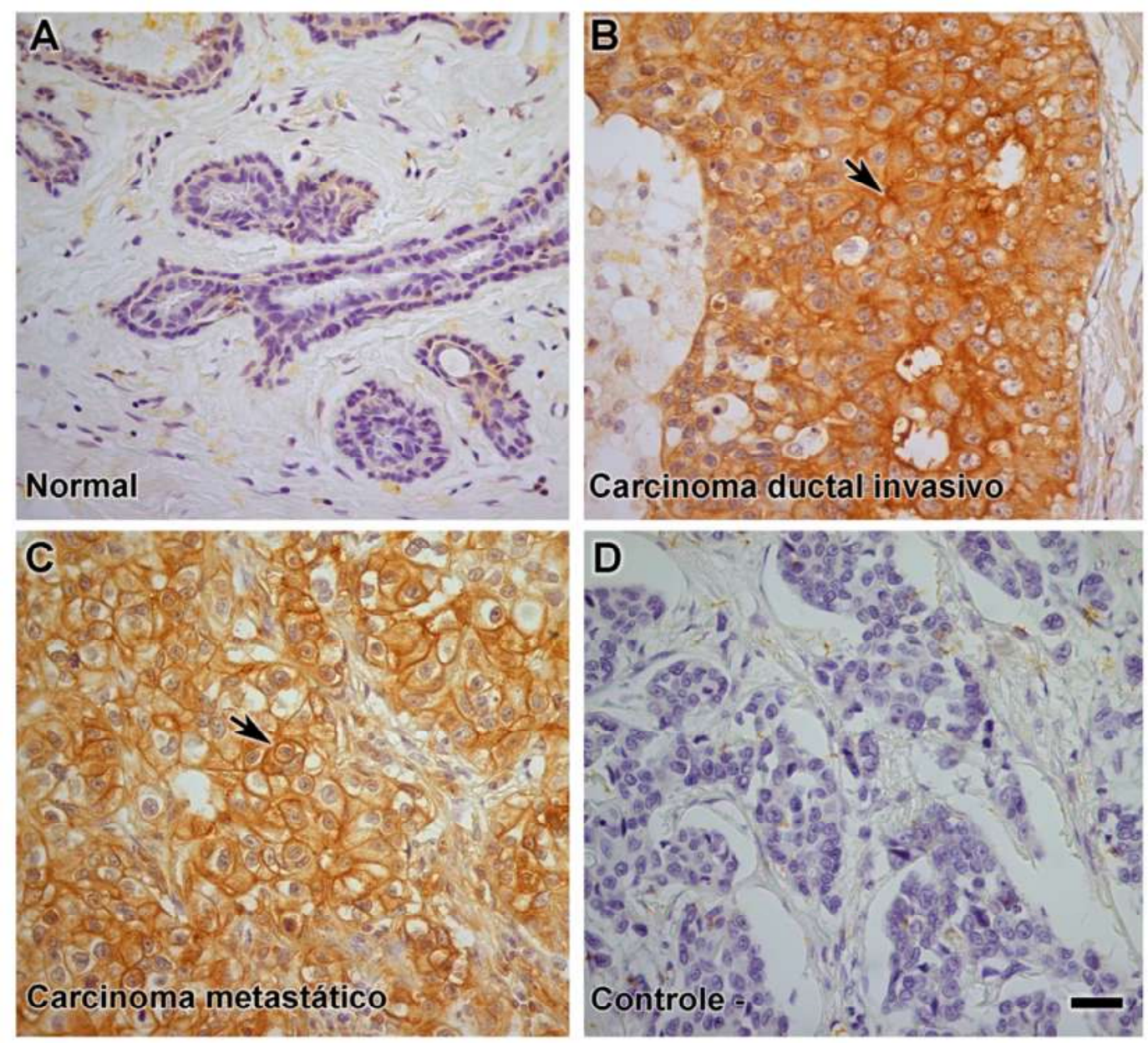

E

IHQ: AHNAK

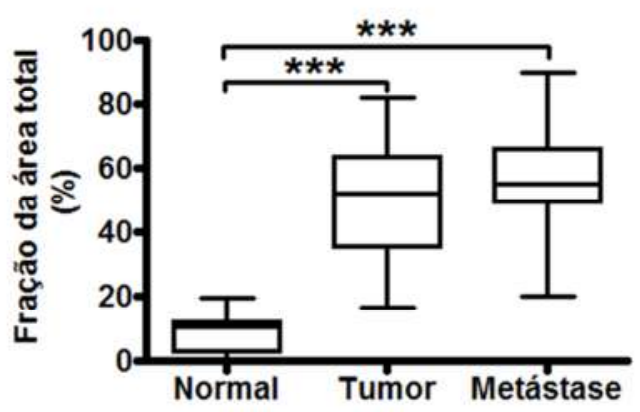

Figura 18 - AHNAK é mais abundante no tecido tumoral e no carcinoma metastático, quando comparado com o tecido normal. 
Figura 18 - AHNAK é mais abundante no tecido tumoral e no carcinoma metastático, quando comparado com o tecido normal. Imunohistoquímica para AHNAK no tecido normal (A), carcinoma ductal invasivo (B) e carcinoma metastático (C). (A) Distribuição no tecido normal de mama para AHNAK é discreta e localizada em torno dos tubos. Em contraste, a expressão de AHNAK é mais proeminente no carcinoma ductal invasivo (B) e o carcinoma metastático (C). Marcação para AHNAK está localizada principalmente na membrana da célula tumoral (B e $\mathrm{C}$, setas). Na periferia do tumor adjacente ao tecido conjuntivo, a proteína AHNAK está difusa no citoplasma. Análise da área marcada mostra que o tecido tumoral e metastático expressam mais AHNAK do que tecido mamário normal (E). One-way ANOVA com pós-teste de Bonferroni mostra diferença estatisticamente significativa entre os grupos analisados $(* * *, p=0,0001)$. Os dados representam média \pm erro da média. Escala: $20 \mu \mathrm{m}$. 


\section{DISCUSSÃO}

Neste estudo, demonstramos a presença e troca de vesículas heterogêneas entre as células tumorais de mama e células estromais na co-cultura. Detectamos que as células tumorais apresentam mais vesículas que as células normais. As vesículas isoladas da linhagem celular MDA-MB-231 induziram a proliferação e a ativação da via ERK 1/2 em células MCF-7. Na análise proteômica das vesículas da célula MDA-MB-231, identificamos a proteína AHNAK. Através de análises morfológicas e "immunoblot” foi confirmada a presença de AHNAK nas vesículas estudadas. AHNAK silenciada promoveu a redução na migração, na invasão celular e na troca de vesículas, bem como a diminuição das protrusões celulares e da produção de vesículas. Observamos também que a proteína AHNAK é mais expressa em tumores da mama e tecido metastático, quando comparado com o tecido normal.

O desenvolvimento do câncer está relacionado com a interação entre células tumorais e seu estroma (HU; POLYAK, 2008). O estroma tumoral, incluindo a MEC, as células endoteliais, fibroblastos e células inflamatórias pode afetar a progressão do câncer (HU; POLYAK, 2008; TLSTY; COUSSENS, 2006). Estudos recentes sugerem que a interação entre as células pode ser mediada por trocas de vesículas extracelulares (RAPOSO; STOORVOGEL, 2013). Em nosso trabalho, demonstramos a presença e a troca de vesículas heterogêneas entre as células tumorais de mama e as células estromais. Além disso, observamos que as células tumorais produzem mais vesículas, quando comparado com fibroblastos não tumorais in vitro.

Em nossos ensaios de co-cultura, observou-se a formação e a interação de células tumorais e fibroblastos através de vesículas (microscopia confocal). Uma vez que o câncer é uma doença influenciada e dependente do estroma adjacente (HU; POLYAK, 2008), a presença de vesículas em ambas as células (tumorais e estromais) pode modular o crescimento invasivo do tumor primário, a adesão, o processo de neovascularização, bem como levar à supressão imunológica e quimiorresistência (HENDRIX; HUME, 2011). Algumas vesículas podem mover-se para órgãos distantes, por meio da difusão, promover metástases e levar ao desenvolvimento de tumores em outros tecidos (HENDRIX; HUME, 2011; KUCHARZEWSKA; BELTING, 2013).

A presença de vesículas trocadas por células nos levou a caracterizar essas estruturas através do MET, proteômica, análise pelo NanoSight e imunofluorescência. 
Os resultados de co-cultura, mostraram estruturas vesiculares de tamanhos heterogêneos (a partir de $500 \mathrm{~nm}$ a $1 \mu \mathrm{m}$ ). No entanto, com o auxílio de outros métodos complementares, observamos que as vesículas derivadas das células estudadas possuem tamanhos diversos a partir de $10 \mathrm{~nm}$ de diâmetro até $750 \mathrm{~nm}$, e esse tamanho foi limitado pelo método de filtração que utilizamos no isolamento das vesículas. Vale ressaltar que o tamanho mais representativo das vesículas presentes na nossa amostra é 200-300 nm. Vesículas com tamanhos maiores do que $100 \mathrm{~nm}$ podem ser originadas por brotamento a partir da membrana plasmática (KUCHARZEWSKA; BELTING, 2013), o que indica que as vesículas isoladas e caracterizadas neste estudo podem ser originadas a partir das protrusões da membrana plasmática.

Os nossos resultados mostraram concentrações mais elevadas de vesículas em células tumorais da mama, em comparação com os fibroblastos. Maiores concentrações de microvesículas, também foram observados por outros grupos, em células tumorais (MDA-MB-231) em relação aos fibroblastos (NIH 3T3) (ANTONYAK et al., 2011). Células de câncer de mama (B42 clone 16) apresentaram maior número de exossomos, quando comparadas com as células normais da mama epiteliais (HMEC B42) (RICHES et al., 2014). Células-tronco de carcinomas renais também secretaram grande quantidade de vesículas extracelulares (LINDOSO; COLLINO; CAMUSSI, 2015).

Através de MEV, também observamos maiores quantidade de vesículas nas células tumorais de mama quando comparadas com células normais. Microvesículas também foram observadas em linhagens celulares altamente tumorigênicas, como células derivadas de glioblastoma humano (SKOG et al., 2008). Shao e colaboradores (2012) também observaram, através de MEV, que as células de glioblastoma humanas primárias (GBM20/3) produziam grande número de microvesículas (SHAO et al., 2012).

Mantivemos as células em meio livre de soro durante 24 horas. Fatores como hipóxia, acidose, carenciamento, estresse oxidativo e métodos terapêuticos anticancerígeno podem influenciar a promoção e a liberação de vesículas extracelulares. Tais fatores podem também modular o nível de secreção da vesícula e a sua atividade funcional (KUCHARZEWSKA; BELTING, 2013). A liberação destas estruturas pode ser induzida pela ativação de receptores de superfície celular e podem atingir o interior das células alvo, quer através da fusão com a membrana plasmática ou por endocitose (KUCHARZEWSKA; BELTING, 2013). 
Observamos por MET a presença de projeções celulares, que poderiam liberar as vesículas das células tumorais ou normais. Microvesículas podem ser vesículas extracelulares que são eliminadas a partir da membrana plasmática, no entanto, os mecanismos envolvidos na liberação de vesículas permanecem a serem investigados (RAPOSO; STOORVOGEL, 2013).

Devido à presença de grandes vesículas encontradas na co-cultura, como se mostra por meio do microscópio confocal, decidimos realizar um método mais simples de centrifugação, usado para isolar vesículas maiores liberadas pelas células. Assim como o estudo de Crescitelli e colaboradores (2013), que também isolou microvesículas com baixa centrifugação (12.200 g por 40 minutos), mostrando que os protocolos baseados em centrifugação são sistemas simples e rápidos para separar as vesículas extracelulares (CRESCITELLI et al., 2013). A centrifugação de 10.000-20.000 g isola vesículas maiores do que $100 \mathrm{~nm}$ (WITWER et al., 2013) e a ultracentrifugação (100.000 g) é usada para isolar vesículas menores, de 50 a 90 nm (THÉRY et al., 2006; WITWER et al., 2013).

Um único tipo celular pode libertar vesículas extracelulares de diferentes tipos e tamanhos, incluindo exossomos $(<100 \mathrm{~nm})$ e microvesículas maiores $(>100 \mathrm{~nm})$, que podem transportar diferentes conteúdos com várias propriedades biológicas (RICHES et al., 2014). Heijnen e colaboradores (1999) mostraram que plaquetas ativadas apresentaram duas populações distintas de vesículas, de acordo com a origem e composição, sendo uma população de microvesículas, derivadas a partir da superfície da membrana plasmática, e outra população de exossomos originada a partir da exocitose de corpos multivesiculares e grânulos (HEIJNEN et al., 1999).

A análise das imagens obtidas por MET, mostrou a presença de vesículas heterogêneas, estruturas liberadas pelas células, com diferentes densidades eletrônica e diâmetros variando entre 200 e $700 \mathrm{~nm}$. Assim como em nossos resultados, Crescitelli e colaboradores (2013), também mostraram que vesículas isoladas de células de microglia BV-2 (murine), tinham aspecto predominantemente redondo e oval, ligadas à membrana, de tamanho e a densidade eletrônica variável, dentro do intervalo de diâmetro de 200 a $800 \mathrm{~nm}$ (CRESCITELLI et al., 2013). Além disso, uma linhagem celular de melanoma, analisados por MET, também liberaram microvesículas de tamanhos heterogêneos $(300-900 \mathrm{~nm})$ e exossomos $(50-70 \mathrm{~nm})$ (MURALIDHARANCHARI et al., 2009). 
Alguns estudos sugerem que as estruturas vesiculares contribuem para os processos fisiológicos e patológicos, tais como a modulação da resposta imunológica, as doenças neurodegenerativas, a difusão de partículas virais e a transferência dos receptores de sinalização de células oncogênicas adjacentes (SIMONS; RAPOSO, 2009). Exossomos são poderosos meios de comunicação intercelular, que podem ser liberados por fibroblastos e desempenhar papel na proliferação celular, motilidade e metástases de células tumorais de mama (LUGA et al., 2012).

A análise proteômica de estruturas vesiculares resultantes de células MDA-MB231, mostrou a presença de AHNAK (proteína associada à diferenciação de neuroblasto), Anexina A2, Anexina A6, S100-A10, entre outros. Interessantemente, estas proteínas fazem parte de uma estrutura chamada "enlargeossomo", que é descrito em neurônios e estão associadas ao aumento da exocitose nas células, através de vesículas da superfície citoplasmática (BORGONOVO et al., 2002; LORUSSO et al., 2006; RACCHETTI et al., 2010). O reparo de membrana mediado por um complexo multiprotéico foi relacionado ao complexo S100A10-Anexina A2, com a presença de AHNAK (REZVANPOUR; SANTAMARIA-KISIEL; SHAW, 2011). Os nossos resultados identificaram a proteína AHNAK em estruturas vesiculares que derivaram de células MDA-MB-231 (tumorais de mama), assim como descrito na literatura, após análise proteômica de células tumorais da próstata (HOSSEINI-BEHESHTI et al., 2012) e em vesículas de células tumorais de mama MCF-7 (KRUGER et al., 2014). A Anexina A2 é uma proteína ligada a fosfolipídios, necessária para a regulação da exocitose de vesículas (CHASSEROT-GOLAZ et al., 2005; LORUSSO et al., 2006). Além disso, Anexina A2 foi identificada em microvesículas de células tumorais de mama MCF-7 e MDA-MB-231 (STAUBACH; RAZAWI; HANISCH, 2009), bem como na linhagem celular de glioblastoma U87 (ANTONYAK et al., 2011) e em células tumorais de próstata (HOSSEINI-BEHESHTI et al., 2012). A Anexina A6 é membro da família de proteínas de ligação da membrana, dependentes de $\mathrm{Ca}^{2+}$. Enrich e colaboradores (2011) mostraram que a Anexina A6 liga-se aos fosfolipídios das membranas celulares durante a regulação das vias endocíticas e exocíticas. De modo geral, as Anexinas são proteínas que se ligam a fosfolipídios dependentes de cálcio e que desempenham papel importante na regulação do crescimento celular e nas vias de transdução de sinais (ENRICH et al., 2011). 
Após ensaio da proteômica, analisamos a expressão da proteína AHNAK em células tumorais e fibroblastos em monocultura e em co-cultura. A principal localização de AHNAK é na membrana plasmática (GENTIL et al., 2003), visto que esta é uma proteína citosólica localizada na face intracelular da membrana e que não apresenta o domínio transmembrânico (BENAUD et al., 2004). Nossos resultados mostraram a proteína AHNAK distribuída ao longo da membrana plasmática das células, além do mais, também foi identificada nas estruturas vesiculares. Em co-cultura, a troca de vesículas entre as células foi notável. De maneira interessante, observamos a colocalização de AHNAK com a vesícula de células tumorais MDA-MB-231 doada para os fibroblastos, sugerindo que a proteína AHNAK é importante para a formação destas estruturas vesiculares. Borgonovo e colaboradores (2002) mostram que AHNAK está localizada dentro do lúmen de vesículas específicas quando a célula está em repouso, no entanto, pode ser observada na superfície das células após algum estímulo. Vesículas apresentando AHNAK foram encontradas em vários tipos de tecidos e células, e podem estar envolvidas no processo de diferenciação e reparação da membrana celular (BORGONOVO et al., 2002).

O efeito positivo das vesículas isoladas a partir de vários tipos de células tumorais foi observado em diferentes ensaios in vitro, tal como proliferação, invasão, migração e outros processos celulares (ANSA-ADDO et al., 2010; GALINDO-HERNANDEZ et al., 2014; HARRIS et al., 2015; KIM, J. et al., 2014; MENCK et al., 2015). As vesículas isoladas a partir de células MDA-MB-231 (40 $\mu \mathrm{g} / \mathrm{ml})$ foram capazes de promover a proliferação de células tumorais de mama MCF-7 (menos tumorigênicas e menos metastáticas), no entanto, os fibroblastos não tumorais e as células MCF-10A não apresentaram diferenças significativas na proliferação celular. Curiosamente, embora os nossos resultados demonstrarem que as vesículas isoladas a partir de células MDA-MB231 estimularam a proliferação de células MCF-7, estas vesículas foram incapazes de promover a proliferação da própria linhagem celular MDA-MB-231 da qual foi isolada; bem como observado por Menck e colaboradores (2015), ao passo que as microvesículas derivadas de células tumorais MCF-7 e SK-BR-3 (10 $\mu \mathrm{g} / \mathrm{ml})$ não afetaram a proliferação das próprias células MCF-7 e SK-BR-3 doadoras de vesículas, mesmo após 96 horas de incubação (MENCK et al., 2015).

Tendo estes resultados na proliferação de MCF-7, nosso próximo objetivo foi avaliar os mecanismos envolvidos na proliferação celular mediada por vesículas. 
Raimondo e colaboradores (2015) mostraram que exossomos derivados da linhagem celular humana LAMA84 de leucemia mielóide crónica $(10 \mu \mathrm{g} / \mathrm{ml})$ foram capazes de promover uma moderada fosforilação de ERK após 72 horas de tratamento e o aumento da fosforilação de PKB ou PI3K-Akt, após 96 horas de tratamento das células LAMA84 (RAIMONDO et al., 2015). Além disso, Qu e colaboradores (2009) mostraram que a ativação das vias de sinalização PI3K-Akt e ERK 1/2 mediaram a proliferação da linhagem celular de câncer gástrico SGC7901, após estimulação dos próprios exossomos $(200 \mu \mathrm{g} / \mathrm{ml})$ durante 24,48 e 72 horas, de forma tempo-dependente (QU et al., 2009).

Uma vez que as vias de sinalização ERK e PI3K-Akt são responsáveis pela regulação da proliferação e outros processos (RAIMONDO et al., 2015), avaliamos a ativação de ERK e PI3K-Akt após estímulos proliferativos com vesículas isoladas. Os nossos resultados demonstraram que o tratamento com as vesículas isoladas a partir de células MDA-MB-231 (40 $\mu \mathrm{g} / \mathrm{ml})$, aumentou a taxa de fosforilação de ERK 1/2 em células MCF-7, após 30 minutos e 2 horas de estímulos, sugerindo que esta via de sinalização está envolvida com a proliferação das células tumorais de mama mediada por vesículas.

O efeito das vesículas isoladas a partir de uma linhagem celular, incubadas em outro diferente tipo de célula foi observada por Kim e colaboradores (2014), ao passo que as vesículas extracelulares isoladas $(20 \mu \mathrm{g} / \mathrm{ml})$ a partir de células DU145 com DIAPH3 depletado (gene supressor de metástases) foram capazes de estimular a proliferação de células tumorais de próstata humana DU145 e LNCaP, e de células de carcinoma da bexiga T24 (após 72 horas de incubação) bem como, inibiram a proliferação de macrófagos de camundongos e de células mononucleares de sangue periférico humano (células imunes) (KIM, J. et al., 2014). Neste estudo, ERK1/2 induziu a liberação de vesículas extracelulares ativadas por vias oncogênicas de transdução de sinais e estimulou a proliferação de células tumorais receptoras (KIM, J. et al., 2014). Além disso, Ansa-Addo e colaboradores (2010) estudaram vesículas derivadas de membrana plasmática (PMVs) isoladas a partir de células de leucemia promonocíticas THP-1. Neste trabalho, PMVs $(10 \mu \mathrm{g} / \mathrm{ml})$ reduziram a proliferação de células THP-1 (após 48 horas) e induziram a diferenciação terminal de monócitos de sangue periférico primárias, bem como de células THP-1 (ANSA-ADDO et al., 2010). 
Para melhor compreender o papel da proteína AHNAK em células MDA-MB231, silenciamos esta proteína através de transfecção com siRNA. O silenciamento de AHNAK não afetou a viabilidade e a capacidade de proliferação celular, enquanto que inibiu a atividade migratória e invasiva das células MDA-MB-231 in vitro. Shankar e colaboradores (2010) demonstraram que a viabilidade de células MDA-MB-231 transfectadas com AHNAK-siRNA também não foi afetada, apesar disso, resultou na retração de pseudópodes, redução da dinâmica do citoesqueleto de actina, reversão da transição epitélio-mesenquimal e inibição da migração e invasão celular (SHANKAR et al., 2010). Sudo e colaboradores (2014) também encontraram AHNAK em células de mesotelioma. Realizaram ensaios de migração e invasão destas células, e observaram aumentada atividade destas células tumorais quando comparadas com células normais. AHNAK silenciada reduziu significativamente a capacidade de migração e invasão das células de mesotelioma (SUDO et al., 2014). Benaud e colaboradores (2004) observaram que AHNAK teve efeito na organização do citoesqueleto de actina, de modo a suportar a altura da célula (BENAUD et al., 2004).

Curiosamente, o número de protrusões celulares diminuiu após o silenciamento de AHNAK, como observado anteriormente por Shankar e colaboradores (SHANKAR et al., 2010). Além disso, observou-se a diminuição na produção de vesículas das células MDA-MB-231 AHNAK-siRNA, em comparação com os seus homólogos basais. Nós previamente supomos que as projeções poderiam liberar as vesículas celulares a partir das células, ao passo que microvesículas podem ser vesículas extracelulares que brotam da membrana plasmática (RAPOSO; STOORVOGEL, 2013), por conseguinte, a diminuição das protrusões celulares poderia estar relacionada com o decréscimo do número de vesículas produzidas pelas células.

No nosso estudo, o silenciamento da proteína AHNAK foi capaz de afetar a presença e troca de vesículas observadas na linhagem de células tumorais de mama, uma vez que nossos resultados descreveram um decréscimo no número de vesículas a partir de células tumorais MDA-MB-231 AHNAK-siRNA doadas para fibroblastos não tumorais quando comparado com as células MDA-MB-231 (controle). E também observamos diminuição de microvesículas em células MDA-MB-231 AHNAK silenciadas quando comparada com controle. Mostrando que de alguma maneira a proteína AHNAK também estaria envolvida na formação e troca de vesículas. 
A presença de AHNAK em amostras tumorais e normais de mama foi investigada por IHQ. Amostras de mama normais apresentaram baixa expressão de AHNAK como descrito na literatura (GENTIL et al., 2003), no entanto, amostras tumorais de mama e metastáticas apresentaram marcação para AHNAK bastante intensa. Sudo e colaboradores (2014) também observaram, através de IHQ, elevada expressão de AHNAK em tecidos de mesotelioma de xenoenxertos e também de humanos, quando comparado com tecidos normais (SUDO et al., 2014).

Curiosamente, em nossos resultados, o padrão de marcação de AHNAK na mesma amostra tumoral e nas células tumorais MCF-7 apresentam diferenças de acordo com a localização celular. As células da periferia do tumor apresentaram AHNAK distribuída por todo o citoplasma, enquanto que as células do centro do tumor mostraram AHNAK predominantemente na membrana plasmática. A divergência sobre a localização de AHNAK pode ser esclarecida pela capacidade desta proteína ser transportada entre os diversos compartimentos subcelulares (DUMITRU et al., 2013). Benaud e colaboradores (2004) mostraram que AHNAK é distribuída a partir do citoplasma para a membrana plasmática de acordo com o aumento da densidade celular (BENAUD et al., 2004). Apesar do trabalho recente descrevendo AHNAK como um supressor tumoral (LEE et al., 2014), o aumento de AHNAK no tumor em comparação com tecidos normais, também foi descrita em pacientes com melanoma (SHTIVELMAN; BISHOP, 1993) e amostras humanas de câncer de laringe (DUMITRU et al., 2013).

O papel das vesículas secretadas a partir de células do câncer de mama ainda é desconhecido, mas é fato que essas vesículas podem manipular o microambiente tumoral e afetar a tumorigênese. Mais estudos são necessários para responder quais são as mensagens levadas pelas vesículas e como estas, poderiam afetar os processos celulares envolvidos com progressão tumoral. Os nossos resultados evidenciam que as vesículas a partir de células tumorais de mama são competentes para alterar o comportamento de outras células através da ativação de diferentes vias de sinalização, por exemplo, modular a proliferação celular. A proteína AHNAK pode ser uma molécula candidata a influenciar a biologia dos tumores de mama. Portanto, definir o mecanismo de interações célula-célula através de vesículas será a nossa próxima etapa a fim de esclarecer este importante aspecto na biologia do câncer de mama. 


\section{CONCLUSÃO}

Baseado nos nossos resultados, concluímos que:

- Existe a presença e troca de vesículas entre as células tumorais e fibroblastos não tumorais quando co-cultivados;

- Células tumorais produzem mais vesículas do que fibroblastos;

- Vesículas isoladas de células MDA-MB-231 induzem a proliferação de células MCF-7 por meio da ativação de ERK 1/2;

- AHNAK está presente entre as proteínas que formam as microvesículas;

- AHNAK está localizada nas vesículas trocados entre células tumorais e fibroblastos;

- AHNAK é importante para a migração, invasão celular e troca de vesículas, bem como, a depleção de AHNAK reduz o número de protrusões celulares e a liberação de vesículas;

- AHNAK é superexpressa em tumores de mama, quando comparado com o tecido normal. 


\section{REFERÊNCIAS*}

AMERICAN CANCER SOCIETY - ACS. Disponível em: $<$ http://www.cancer.org/cancer/breastcancer/>. Acesso em: Julho, 2015.

ANDERSON, H. C. Vesicles associated with calcification in the matrix of epiphyseal cartilage. J. Cell Biol., v. 41, n. 1, p. 59-72, Abr 1969.

ANSA-ADDO, E. A. et al. Human plasma membrane-derived vesicles halt proliferation and induce differentiation of THP-1 acute monocytic leukemia cells. J. Immunol., v. 185, n. 9, p. 5236-5246, Nov 2010.

ANTONYAK, M. A. et al. Cancer cell-derived microvesicles induce transformation by transferring tissue transglutaminase and fibronectin to recipient cells. Proc. Natl. Acad. Sci. USA, v. 108, n. 12, p. 4852-4857, Mar 2011.

ARAKELYAN, A. et al. Antigenic composition of single nano-sized extracellular blood vesicles. Nanomedicine, v. 11, n. 3, p.489-498, Dez 2014.

BENAUD, C. et al. AHNAK interaction with the annexin 2/S100A10 complex regulates cell membrane cytoarchitecture. J. Cell Biol., v. 164, n. 1, p. 133-144, Jan 2004.

BEST, M. G. et al. Liquid biopsies in patients with diffuse glioma. Acta. Neuropathol., v. 129, n. 6, p. 849-865, Jun 2015.

BHOWMICK, N. A.; NEILSON, E. G.; MOSES, H. L. Stromal fibroblasts in cancer initiation and progression. Nature, v. 432, n. 7015, p. 332-337, Nov 2004.

\footnotetext{
*De acordo com: ASSOCIAÇÃO BRASILEIRA DE NORMAS TÉCNICAS. NBR 6023: informação e documentação: referências: elaboração. Rio de Janeiro, 2002.
} 
BORGES, V. F.; SCHEDIN, P. J. Pregnancy-associated breast cancer: an entity needing refinement of the definition. Cancer, v. 118, n. 13, p. 3226-3228, Jul 2012.

BORGONOVO, B. et al. Regulated exocytosis: a novel, widely expressed system. Nat. Cell Biol., v. 4, n. 12, p. 955-962, Dez 2002.

BURTON, E. R.; LIBUTTI, S. K. Targeting TNF-alpha for cancer therapy. J. Biol., v. 8, p. 85.1-85.5, 2009.

CAMP, J. T. et al. Interactions with fibroblasts are distinct in Basal-like and luminal breast cancers. Mol. Cancer Res., v. 9, n. 1, p. 3-13, Jan 2011.

CHARGAFF, E.; WEST, R. The biological significance of the thromboplastic protein of blood. J. Biol. Chem., v. 166, n. 1, p. 189-197, Nov 1946.

CHASSEROT-GOLAZ, S. et al. Annexin 2 promotes the formation of lipid microdomains required for calcium-regulated exocytosis of dense-core vesicles. Mol. Biol. Cell, v. 16, n. 3, p. 1108-1119, Mar 2005.

CHOI, D. S. et al. Proteomics of extracellular vesicles: Exosomes and ectosomes. Mass Spectrom. Rev., v. 34, n. 4, p. 474-490, Jul 2015.

COCUCCI, E.; MELDOLESI, J. Ectosomes and exosomes: shedding the confusion between extracellular vesicles. Trends Cell Biol., v. 25, n. 6, p. 364-372, Jun 2015.

COCUCCI, E.; RACCHETTI, G.; MELDOLESI, J. Shedding microvesicles: artefacts no more. Trends Cell Biol., v. 19, n. 2, p. 43-51, Fev 2009.

COLOMBO, M.; RAPOSO, G.; THÉRY, C. Biogenesis, secretion, and intercellular interactions of exosomes and other extracellular vesicles. Annu. Rev. Cell Dev. Biol., v. 30, p. 255-289, 2014. 
CONDE-VANCELLS, J. et al. Characterization and comprehensive proteome profiling of exosomes secreted by hepatocytes. J. Proteome Res., v. 7, n. 12, p. 5157-5166, Dez 2008.

CRESCITELLI, R. et al. Distinct RNA profiles in subpopulations of extracellular vesicles: apoptotic bodies, microvesicles and exosomes. J. Extracell. Vesicles, v. 12, n. 2, p. 1-10, 2013.

D'ASTI, E. et al. Oncogenic extracellular vesicles in brain tumor progression. Front. Physiol., v. 3, n. 294, p. 1-15, 2012.

D'SOUZA-SCHOREY, C.; CLANCY, J. W. Tumor-derived microvesicles: shedding light on novel microenvironment modulators and prospective cancer biomarkers. Genes Dev., v. 26, n. 12, p. 1287-1299, Jun 2012.

D'SOUZA-SCHOREY, C.; DI VIZIO, D. Biology and proteomics of extracellular vesicles: harnessing their clinical potential. Expert. Rev. Proteomics, v. 11, n. 3, p. 251-253, Jun 2014.

DAVIS, T. A.; LOOS, B.; ENGELBRECHT, A. M. AHNAK: the giant jack of all trades. Cell Signal., v. 26, n. 12, p. 2683-2693, Dez 2014.

DE MAIO, A. Extracellular heat shock proteins, cellular export vesicles, and the Stress Observation System: a form of communication during injury, infection, and cell damage. It is never known how far a controversial finding will go! Dedicated to Ferruccio Ritossa. Cell Stress Chaperon., v. 16, n. 3, p. 235-249, Maio 2011.

DEBNATH, J.; MUTHUSWAMY, S. K.; BRUGGE, J. S. Morphogenesis and oncogenesis of MCF-10A mammary epithelial acini grown in three-dimensional basement membrane cultures. Methods, v. 30, n. 3, p. 256-268, Jul 2003. 
DONG-LE BOURHIS, X. et al. Effect of stromal and epithelial cells derived from normal and tumorous breast tissue on the proliferation of human breast cancer cell lines in co-culture. Int. J. Cancer, v. 71, n. 1, p. 42-48, Mar 1997.

DUBREUIL, V. et al. Midbody and primary cilium of neural progenitors release extracellular membrane particles enriched in the stem cell marker prominin-1. J. Cell Biol., v. 176, n. 4, p. 483-495, Fev 2007.

DUMITRU, C. A. et al. AHNAK and inflammatory markers predict poor survival in laryngeal carcinoma. PLoS One, v. 8, n. 2, p. 1-9, 2013.

EL ANDALOUSSI, S. et al. Extracellular vesicles: biology and emerging therapeutic opportunities. Nat. Rev. Drug Discov., v. 12, n. 5, p. 347-357, Maio 2013.

ENRICH, C. et al. Annexin A6-Linking $\mathrm{Ca}(2+)$ signaling with cholesterol transport. Biochim. Biophys. Acta, v. 1813, n. 5, p. 935-947, Maio 2011.

GALINDO-HERNANDEZ, O. et al. Extracellular vesicles from MDA-MB-231 breast cancer cells stimulated with linoleic acid promote an EMT-like process in MCF10A cells. Prostaglandins Leukot. Essent. Fatty Acids, v. 91, n. 6, p. 299-310, Dez 2014.

GENTIL, B. J. et al. Expression of the giant protein AHNAK (desmoyokin) in muscle and lining epithelial cells. J. Histochem. Cytochem., v. 51, n. 3, p. 339-348, Mar 2003.

GOULD, S. J.; RAPOSO, G. As we wait: coping with an imperfect nomenclature for extracellular vesicles. J. Extracell. Vesicles, v. 2, p. 1-3, 2013.

GYÖRGY, B. et al. Membrane vesicles, current state-of-the-art: emerging role of extracellular vesicles. Cell Mol. Life Sci., v. 68, n. 16, p. 2667-2688, Ago 2011.

HANAHAN, D.; WEINBERG, R. A. Hallmarks of cancer: the next generation. Cell, v. 144, n. 5, p. 646-674, Mar 2011. 
HANNAFON, B. N.; DING, W. Q. Intercellular Communication by Exosome-Derived microRNAs in Cancer. Int. J. Mol. Sci., v. 14, n. 7, p. 14240-14269, 2013.

HARRIS, D. A. et al. Exosomes released from breast cancer carcinomas stimulate cell movement. PLoS One, v. 10, n. 3, p. 1-18, 2015.

HASHIMOTO, T. et al. Desmoyokin, a $680 \mathrm{kDa}$ keratinocyte plasma membraneassociated protein, is homologous to the protein encoded by human gene AHNAK. J. Cell Sci., v. 105, p. 275-286, Jun 1993.

HEIJNEN, H. F. et al. Activated platelets release two types of membrane vesicles: microvesicles by surface shedding and exosomes derived from exocytosis of multivesicular bodies and alpha-granules. Blood, v. 94, n. 11, p. 3791-3799, Dez 1999.

HENDRIX, A.; HUME, A. N. Exosome signaling in mammary gland development and cancer. Int. J. Dev. Biol., v. 55, n. 7-9, p. 879-887, 2011.

HOLLIDAY, D. L.; SPEIRS, V. Choosing the right cell line for breast cancer research. Breast Cancer Res., v. 13, n. 215, p. 1-7, 2011.

HOSSEINI-BEHESHTI, E. et al. Exosomes as biomarker enriched microvesicles: characterization of exosomal proteins derived from a panel of prostate cell lines with distinct AR phenotypes. Mol. Cell Proteomics, v. 11, n. 10, p. 863-885, Out 2012.

HU, M.; POLYAK, K. Microenvironmental regulation of cancer development. Curr. Opin. Genet. Dev., v. 18, n. 1, p. 27-34, Fev 2008.

HUANG, Y. et al. AHNAK, a novel component of the dysferlin protein complex, redistributes to the cytoplasm with dysferlin during skeletal muscle regeneration. FASEB J., v. 21, n. 3, p. 732-742, Mar 2007.

INSTITUTO NACIONAL DO CÂNCER /MINISTÉRIO DA SAÚDE - INCA/MS. Disponível em: <http://www.inca.gov.br>. Acesso em: Março, 2015. 
JOSHI, P. A.; DI GRAPPA, M. A.; KHOKHA, R. Active allies: hormones, stem cells and the niche in adult mammopoiesis. Trends Endocrinol. Metab., v. 23, n. 6, p. 299309, Jun 2012.

KALlURI, R.; ZEISBERG, M. Fibroblasts in cancer. Nat. Rev. Cancer, v. 6, n. 5, p. 392-401, Maio 2006.

KALRA, H. et al. Vesiclepedia: a compendium for extracellular vesicles with continuous community annotation. PLoS Biol., v. 10, n. 12, p. 1-5, 2012.

KARLSSON, M. et al. "Tolerosomes" are produced by intestinal epithelial cells. Eur. J. Immunol., v. 31, n. 10, p. 2892-2900, Out 2001.

KERR, J. F.; WYLlIE, A. H.; CURRIE, A. R. Apoptosis: a basic biological phenomenon with wide-ranging implications in tissue kinetics. Br. J. Cancer, v. 26, n. 4, p. 239-257, Ago 1972.

KIM, D. K. et al. EVpedia: a community web portal for extracellular vesicles research. Bioinformatics, v. 31, n. 6, p. 933-939, Mar 2015.

KIM, J. et al. Enhanced shedding of extracellular vesicles from amoeboid prostate cancer cells: potential effects on the tumor microenvironment. Cancer Biol. Ther., v. 15, n. 4, p. 409-418, Abr 2014.

KLEIFELD, O. et al. Identifying and quantifying proteolytic events and the natural $\mathrm{N}$ terminome by terminal amine isotopic labeling of substrates. Nat. Protoc., v. 6, n. 10, p. 1578-1611, Out 2011.

KLEMM, F.; JOYCE, J. A. Microenvironmental regulation of therapeutic response in cancer. Trends Cell Biol., v. 25, n. 4, p. 198-213, Abr. 2015. 
KOUNO, M. et al. Ahnak/Desmoyokin is dispensable for proliferation, differentiation, and maintenance of integrity in mouse epidermis. J. Invest. Dermatol., v. 123, n. 4, p. 700-707, Out 2004.

KRUGER, S. et al. Molecular characterization of exosome-like vesicles from breast cancer cells. BMC Cancer, v. 14, n. 44, p. 1-10, 2014.

KUCHARZEWSKA, P.; BELTING, M. Emerging roles of extracellular vesicles in the adaptive response of tumour cells to microenvironmental stress. J. Extracell. Vesicles, v. 2, p. 1-10, 2013.

KUHBIER, J. W. et al. Observed changes in the morphology and phenotype of breast cancer cells in direct co-culture with adipose-derived stem cells. Plast. Reconstr. Surg., v. 134, n. 3, p. 414-423, Set 2014.

LE, M. T. et al. miR-200-containing extracellular vesicles promote breast cancer cell metastasis. J. Clin. Invest., v. 124, n. 12, p. 5109-5128, Dez 2014.

LEE, I. H. et al. Ahnak functions as a tumor suppressor via modulation of TGF $\beta / \mathrm{Smad}$ signaling pathway. Oncogene, v. 33, n. 38, p. 4675-4684, Set 2014.

LEHNER, B. et al. The dark side of BrdU in neural stem cell biology: detrimental effects on cell cycle, differentiation and survival. Cell Tissue Res., v. 345, n. 3, p. 313328 , Set 2011.

LESTER, S. C.; COTRAN, R. S. A mama. In: COTRAN, R. S.; KUMAR, V.; COLLINS, T. ROBBINS Patologia estrutural e funcional. 6. Ed. Rio de Janeiro: Guanabara-Koogan, 2000. Cap. 25, p. 979-1002.

LI, X. et al. Regulation of miRNA expression by Src and contact normalization: effects on nonanchored cell growth and migration. Oncogene, v. 28, n. 48, p. 4272-4283, Dez 2009. 
LINDOSO, R. S.; COLLINO, F.; CAMUSSI, G. Extracellular vesicles derived from renal cancer stem cells induce a pro-tumorigenic phenotype in mesenchymal stromal cells. Oncotarget, v. 6, n. 10, p. 7959-7969, Abr 2015.

LORUSSO, A. et al. Annexin2 coating the surface of enlargeosomes is needed for their regulated exocytosis. EMBO J., v. 25, n. 23, p. 5443-5456, Nov 2006.

LUGA, V. et al. Exosomes mediate stromal mobilization of autocrine Wnt-PCP signaling in breast cancer cell migration. Cell, v. 151, n. 7, p. 1542-1556, Dez 2012.

LÖTVALL, J. et al. Minimal experimental requirements for definition of extracellular vesicles and their functions: a position statement from the International Society for Extracellular Vesicles. J. Extracell. Vesicles, v. 3, p. 1-6, 2014.

MAHR, D. M.; BHARGAVA, R.; INSANA, M. F. Three-dimensional in silico breast phantoms for multimodal image simulations. IEEE Trans. Med. Imaging, v. 31, n. 3, p. 689-697, Mar 2012.

MARTINS, V. R.; DIAS, M. S.; HAINAUT, P. Tumor-cell-derived microvesicles as carriers of molecular information in cancer. Curr. Opin. Oncol., v. 25, n. 1, p. 66-75, Jan 2013.

MATHIVANAN, S.; JI, H.; SIMPSON, R. J. Exosomes: extracellular organelles important in intercellular communication. J. Proteomics, v. 73, n. 10, p. 1907-1920, Set 2010.

MENCK, K. et al. Tumor-derived microvesicles mediate human breast cancer invasion through differentially glycosylated EMMPRIN. J. Mol. Cell Biol., v. 7, n. 2, p. 143153, Abr 2015.

MOHAMMADI, H. et al. Evaluation of synthesized platinum nanoparticles on the MCF-7 and HepG-2 cancer cell lines. International Nano Letters. v. 3, n.28, p.1-5. 2013. 
MURALIDHARAN-CHARI, V. et al. ARF6-regulated shedding of tumor cell-derived plasma membrane microvesicles. Curr. Biol., v. 19, n. 22, p. 1875-1885, Dez 2009.

MURALIDHARAN-CHARI, V. et al. Microvesicles: mediators of extracellular communication during cancer progression. J. Cell Sci., v. 123, n. 10, p. 1603-1611, Maio 2010.

MURPHY, G. The ADAMs: signalling scissors in the tumour microenvironment. Nat. Rev. Cancer, v. 8, n. 12, p. 929-941, Dez 2008.

OHNO, S.; ISHIKAWA, A.; KURODA, M. Roles of exosomes and microvesicles in disease pathogenesis. Adv. Drug. Deliv. Rev., v. 65, n. 3, p. 398-401, Mar 2013.

PARSONAGE, G. et al. A stromal address code defined by fibroblasts. Trends Immunol., v. 26, n. 3, p. 150-156, Mar 2005.

QU, J. L. et al. Gastric cancer exosomes promote tumour cell proliferation through PI3K/Akt and MAPK/ERK activation. Dig. Liver. Dis., v. 41, n. 12, p. 875-880, Dez 2009.

QUAIL, D. F.; JOYCE, J. A. Microenvironmental regulation of tumor progression and metastasis. Nat. Med., v. 19, n. 11, p. 1423-1437, Nov 2013.

RACCHETTI, G. et al. Rapid neurite outgrowth in neurosecretory cells and neurons is sustained by the exocytosis of a cytoplasmic organelle, the enlargeosome. J. Cell Sci., v. 123, n. 2, p. 165-170, Jan 2010.

RAIMONDO, S. et al. Chronic myeloid leukemia-derived exosomes promote tumor growth through an autocrine mechanism. Cell Commun. Signal., v. 13, n. 8, p. 1-12, 2015. 
RAPOSO, G.; STOORVOGEL, W. Extracellular vesicles: exosomes, microvesicles, and friends. J. Cell Biol., v. 200, n. 4, p. 373-383, Fev 2013.

REZVANPOUR, A.; SANTAMARIA-KISIEL, L.; SHAW, G. S. The S100A10annexin A2 complex provides a novel asymmetric platform for membrane repair. $\mathbf{J}$. Biol. Chem., v. 286, n. 46, p. 40174-40183, Nov 2011.

RICHES, A. et al. Regulation of exosome release from mammary epithelial and breast cancer cells - a new regulatory pathway. Eur. J. Cancer, v. 50, n. 5, p. 1025-1034, Mar 2014.

ROBBINS, P. D.; MORELLI, A. E. Regulation of immune responses by extracellular vesicles. Nat. Rev. Immunol., v. 14, n. 3, p. 195-208, Mar 2014.

SANDVIG, K.; LLORENTE, A. Proteomic analysis of microvesicles released by the human prostate cancer cell line PC-3. Mol. Cell Proteomics, v. 11, n. 7, p. 1-11, Jul 2012.

SANTOS, R. P. et al. Influence of the interaction between nodal fibroblast and breast cancer cells on gene expression. Tumour Biol., v. 32, n. 1, p. 145-157, Fev 2011.

SHANKAR, J. et al. Pseudopodial actin dynamics control epithelial-mesenchymal transition in metastatic cancer cells. Cancer Res., v. 70, n. 9, p. 3780-3790, Maio 2010.

SHAO, H. et al. Protein typing of circulating microvesicles allows real-time monitoring of glioblastoma therapy. Nat. Med., v. 18, n. 12, p. 1835-1840, Dez 2012.

SHEKHAR, M. P. et al. Breast stroma plays a dominant regulatory role in breast epithelial growth and differentiation: implications for tumor development and progression. Cancer Res., v. 61, n. 4, p. 1320-1326, Fev 2001. 
SHTIVELMAN, E.; BISHOP, J. M. The human gene AHNAK encodes a large phosphoprotein located primarily in the nucleus. J. Cell Biol., v. 120, n. 3, p. 625-630, Fev 1993.

SIMONS, M.; RAPOSO, G. Exosomes-vesicular carriers for intercellular communication. Curr. Opin. Cell Biol., v. 21, n. 4, p. 575-581, Ago 2009.

SKOG, J. et al. Glioblastoma microvesicles transport RNA and proteins that promote tumour growth and provide diagnostic biomarkers. Nat. Cell Biol., v. 10, n. 12, p. 14701476, Dez 2008.

SOULE, H. D. et al. Isolation and characterization of a spontaneously immortalized human breast epithelial cell line, MCF-10. Cancer Res., v. 50, n. 18, p. 6075-6086, Set 1990.

STAUBACH, S.; RAZAWI, H.; HANISCH, F. G. Proteomics of MUC1-containing lipid rafts from plasma membranes and exosomes of human breast carcinoma cells MCF-7. Proteomics, v. 9, n. 10, p. 2820-2835, Maio 2009.

STEGMAYR, B.; RONQUIST, G. Promotive effect on human sperm progressive motility by prostasomes. Urol. Res., v. 10, n. 5, p. 253-257, 1982.

STUELTEN, C. H. et al. Transient tumor-fibroblast interactions increase tumor cell malignancy by a TGF-Beta mediated mechanism in a mouse xenograft model of breast cancer. PLoS One, v. 5, n. 3, p. 1-13, 2010.

SUDO, H. et al. AHNAK is highly expressed and plays a key role in cell migration and invasion in mesothelioma. Int. J. Oncol., v. 44, n. 2, p. 530-538, Fev 2014.

SUSSMAN, J. et al. Protein kinase B phosphorylates AHNAK and regulates its subcellular localization. J. Cell Biol., v. 154, n. 5, p. 1019-1030, Set 2001. 
SWARTZ, M. A. et al. Tumor microenvironment complexity: emerging roles in cancer therapy. Cancer Res., v. 72, n. 10, p. 2473-2480, Maio 2012.

TAYLOR, R. C.; CULLEN, S. P.; MARTIN, S. J. Apoptosis: controlled demolition at the cellular level. Nat. Rev. Mol. Cell Biol., v. 9, n. 3, p. 231-241, Mar 2008.

THÉRY, C. et al. Isolation and characterization of exosomes from cell culture supernatants and biological fluids. Curr. Protoc. Cell Biol., capítulo 3, unidade 3.22, p.1-29, Abr 2006.

THÉRY, C.; OSTROWSKI, M.; SEGURA, E. Membrane vesicles as conveyors of immune responses. Nat. Rev. Immunol., v. 9, n. 8, p. 581-593, Ago 2009.

THÉRY, C.; ZITVOGEL, L.; AMIGORENA, S. Exosomes: composition, biogenesis and function. Nat. Rev. Immunol., v. 2, n. 8, p. 569-579, Ago 2002.

TLSTY, T. D.; COUSSENS, L. M. Tumor stroma and regulation of cancer development. Annu. Rev. Pathol., v. 1, p. 119-150, 2006.

TRAMS, E. G. et al. Exfoliation of membrane ecto-enzymes in the form of microvesicles. Biochim. Biophys. Acta., v. 645, n. 1, p. 63-70, Jul 1981.

TURIÁK, L. et al. Proteomic characterization of thymocyte-derived microvesicles and apoptotic bodies in BALB/c mice. J. Proteomics, v. 74, n. 10, p. 2025-2033, Set 2011.

TYAN, S. W. et al. Breast cancer cells induce stromal fibroblasts to secrete ADAMTS1 for cancer invasion through an epigenetic change. PLoS One, v. 7, n. 4, p. 1-11, 2012.

VADER, P.; BREAKEFIELD, X. O.; WOOD, M. J. Extracellular vesicles: emerging targets for cancer therapy. Trends Mol. Med., v. 20, n. 7, p. 385-393, Jul 2014.

VAN DER POL, E. et al. Classification, functions, and clinical relevance of extracellular vesicles. Pharmacol. Rev., v. 64, n. 3, p. 676-705, Jul 2012. 
VAN DOORMAAL, F. F. et al. Cell-derived microvesicles and cancer. Neth. J. Med., v. 67, n. 7, p. 266-273, 2009.

WITWER, K. W. et al. Standardization of sample collection, isolation and analysis methods in extracellular vesicle research. J. Extracell. Vesicles, v. 2, p. 1-25, 2013.

WOLF, P. The nature and significance of platelet products in human plasma. Br. J. Haematol., v. 13, n. 3, p. 269-288, Maio 1967.

YANG, M. et al. Microvesicles secreted by macrophages shuttle invasion-potentiating microRNAs into breast cancer cells. Mol. Cancer, v. 10, n. 117, p. 1-13, 2011.

YOON, Y. J.; KIM, O. Y.; GHO, Y. S. Extracellular vesicles as emerging intercellular communicasomes. BMB Rep., v. 47, n. 10, p. 531-539, Out 2014.

YUANA, Y.; STURK, A.; NIEUWLAND, R. Extracellular vesicles in physiological and pathological conditions. Blood Rev., v. 27, n. 1, p. 31-39, Jan 2013. 
ANEXOS 
A - Tabela das proteínas identificadas na análise proteômica de vesículas derivadas de células tumorais de mama MDA-MB-231. A escala de cor representa a abundância de peptídeos em cada proteína.

\begin{tabular}{|c|c|c|c|}
\hline & \multicolumn{2}{|c|}{ Proteínas identificadas } & \multirow{2}{*}{$\begin{array}{c}\text { Peptídeos } \\
21 \\
\end{array}$} \\
\hline 1 & Q09666;Q6ZQN2;Q8N274;Q13727;B4DTV0 & Neuroblast differentiation-associated protein AHNAK & \\
\hline 2 & P07355-2;P07355;H0YN42;H0YMU9; & Annexin A2;Annexin;Putative annexin A2-like protein & 13 \\
\hline 3 & P11021;Q5IST7;B4DEF7;P54652;B4E1Q1 & $78 \mathrm{kDa}$ glucose-regulated protein & 9 \\
\hline 4 & P21333;P21333-2;Q60FE5;Q60FE6;Q5HY54; & Filamin-A & 8 \\
\hline 5 & P07900-2;K9JA46;P07900;Q8TBA7; & Heat shock protein HSP 90-alpha & 8 \\
\hline 6 & P14625;Q5CAQ5;B4DU71;Q59FC6;B4DHT9; & Endoplasmin & 8 \\
\hline 7 & P30101;B3KQT2;G5EA52;B3KQT9;B4DJ98;B4DDM1 & Protein disulfide-isomerase A3 & 7 \\
\hline 8 & P08238;B4DGL0;B4DMA2;Q6PK50;Q5T9W8;O14942 & Heat shock protein HSP 90-beta & 7 \\
\hline 9 & P14618;P14618-2;B4DRT3;H3BTN5; & Pyruvate kinase isozymes M1/M2;Pyruvate kinase & 7 \\
\hline 10 & P35579;Q60FE2;Q86XU5;P35579-2; & Myosin-9 & 7 \\
\hline 11 & A8K9C4;P68104;Q53G85;Q53GA1; & Elongation factor 1-alpha;Elongation factor 1-alpha 1 & 6 \\
\hline 12 & B7Z2T5;F5H3A1;P05023;B7Z3V1; & Sodium/potassium-transporting ATPase subunit alpha-1; & 6 \\
\hline 13 & B7ZLE5;B7ZLF0;P02751-15;P02751-7;P02751;P02751-11; & Fibronectin;Anastellin;Ugl-Y1;Ugl-Y2;Ugl-Y3 & 6 \\
\hline 14 & O43707;B4E337;B4DSX0;D6PXK4;Q96BG6; & Alpha-actinin-4 & 6 \\
\hline 15 & O75369-8;O75369;O75369-9;O75369-2;O75369-3;O75369-6; & Filamin-B & 6 \\
\hline 16 & P05556;P05556-3;P05556-4;P05556-5;P05556-2;H7C4N8 & Integrin beta-1 & 6 \\
\hline 17 & P26006-1;P26006;B4E0H8;Q59F03;H0YA49;B4DDT0 & Integrin alpha-3; Integrin alpha-3 heavy chain;Integrin alpha-3 light chain & 5 \\
\hline 18 & P00558;B4E1H9;B7Z7A9;B4DHB3;E7ERH5;P07205 & Phosphoglycerate kinase 1;Phosphoglycerate kinase; & 5 \\
\hline 19 & F2XI28;P13746-2;Q5SRN5;A9R9N7; & HLA class I histocompatibility antigen, A-3 alpha chain; & 5 \\
\hline 20 & F8W8J4;Q9NZM1;Q9NZM1-6; & Myoferlin & 5 \\
\hline 21 & P17301;E7ESP4;E7EMF1;E9PB77;Q71V33 & Integrin alpha-2 & 5 \\
\hline 22 & A8K3Q7;P08133;A6NN80;P08133-2; & Annexin;Annexin A6 & 4 \\
\hline 23 & B2RBH2;P21589;Q53Z63;Q6NZX3; & 5-nucleotidase & 4 \\
\hline
\end{tabular}




\begin{tabular}{|c|c|c|c|}
\hline 24 & P68371;Q8IWP6;Q8IZ29;Q8N6N5; & Tubulin beta-4B chain;Tubulin beta-2A chain; & 4 \\
\hline 25 & B4DGP8;P27824;B4E2T8;Q6ZP56;D6RGY2;Q16094; & Calnexin & 4 \\
\hline 26 & B4DHM5;B4DWQ3 & Phosphoglycerate kinase & 4 \\
\hline 27 & B4DY90;P07437;Q5SU16;Q6LC01; & Tubulin beta chain & 4 \\
\hline 28 & B5BU01;P20042;Q6IBR8;Q59GZ3;Q3B719;Q96I16 & Eukaryotic translation initiation factor 2 subunit 2 & 4 \\
\hline 29 & B7TY16;P12814-3;P12814;P12814-2; & Alpha-actinin-1;Alpha-actinin-3;Alpha-actinin-2 & 4 \\
\hline 30 & D0W033;Q95HN1;B0V0C1;Q96QL3; & HLA class I histocompatibility antigen, $\mathrm{Cw}-3$ alpha chain; & 4 \\
\hline 31 & P04083;Q5TZZ9;B5BU38;Q5T3N1;B4DL19;Q5T3N0;Q05BR2 & Annexin A1;Annexin & 4 \\
\hline 32 & P04406;Q2TSD0;E7EUT4;Q0QET7;B4DRV9; & Glyceraldehyde-3-phosphate dehydrogenase & 4 \\
\hline 33 & P04899-4;P04899;Q96C71;B3KTZ0;P04899-2;P04899-3; & Guanine nucleotide-binding protein G(i) subunit alpha-2 & 4 \\
\hline 34 & P06733;P06733-2;E2DRY6;Q9BT62; & Alpha-enolase;Enolase & 4 \\
\hline 35 & P07737;I3L3D5;K7EJ44;CON_P02584 & Profilin-1 & 4 \\
\hline 36 & P29966;Q6NVI1;Q05C82 & Myristoylated alanine-rich C-kinase substrate & 4 \\
\hline 37 & P62258;P62258-2;B7ZA86;G9K388; & 14-3-3 protein epsilon & 4 \\
\hline 38 & Q15149;Q15149-2;Q15149-3;Q15149-6;Q15149-4; & Plectin & 4 \\
\hline 39 & B4DMN1;A5YM50;Q15907;Q6FHR0; & Ras-related protein Rab-11B;Ras-related protein Rab-11A & 3 \\
\hline 40 & A8K486;B2RE56;P62937;Q71V99; & Peptidyl-prolyl cis-trans isomerase;Peptidyl-prolyl cis-trans isomerase A & 3 \\
\hline 41 & Q08431;B3KTQ2;F5H7N9; & Lactadherin;Lactadherin short form;Medin & 3 \\
\hline 42 & P11142;B3KTV0;Q96IS6;P11142-2;Q53HF2;E9PN89;B4DTX2; & Heat shock cognate $71 \mathrm{kDa}$ protein & 3 \\
\hline 43 & P40926;Q6FHZ0;Q75MT9; & Malate dehydrogenase, mitochondrial;Malate dehydrogenase & 3 \\
\hline 44 & P61981;B4DE78;B3KNB4;B4DHC4; & 14-3-3 protein gamma;14-3-3 protein gamma, N-terminally processed & 3 \\
\hline 45 & P61978-2;Q5EC54;Q6IBN1;P61978;B4DFF1;P61978-3; & Heterogeneous nuclear ribonucleoprotein $\mathrm{K}$ & 3 \\
\hline 46 & P60174;P60174-1;B4DUI5;P60174-4;Q2QD09;Q53HE2 & Triosephosphate isomerase & 3 \\
\hline 47 & P27797;Q53G71;B4E2Y9;K7EM77;K7EJB9;B4DHR1 & Calreticulin & 3 \\
\hline 48 & P08195-4;J3KPF3;P08195;F5GZS6;P08195-3; & 4F2 cell-surface antigen heavy chain & 3 \\
\hline 49 & B5BU24;P31946;P31946-2 & 14-3-3 protein beta/alpha;14-3-3 protein beta/alpha, N-terminally processed & 3 \\
\hline 50 & E7EX29;D0PNI1;P63104;E7ESK7;E7EVZ2;E9PD24; & 14-3-3 protein zeta/delta & 3 \\
\hline 51 & P08758;D6RBE9;E7ENQ5;D6RBL5;E9PHT9;B4DNG6;D6RCN3 & Annexin A5;Annexin & 3 \\
\hline
\end{tabular}




\begin{tabular}{|c|c|c|c|}
\hline 52 & H7BZJ3 & Thioredoxin & 3 \\
\hline 53 & J3KPS3;P04075;H3BQN4;H3BPS8;H3BR04; & Fructose-bisphosphate aldolase A;Fructose-bisphosphate aldolase & 3 \\
\hline 54 & O15427;Q53G91;J3KTI8;J3QSC3; & Monocarboxylate transporter 4 & 3 \\
\hline 55 & O43854;Q8N610;O43854-2;B7Z865 & EGF-like repeat and discoidin I-like domain-containing protein 3 & 3 \\
\hline 56 & P05362;Q5NKV8;B4DNT6;K7EKL8;Q15462;O00177 & Intercellular adhesion molecule 1 & 3 \\
\hline 57 & P08754;Q5TZX1;B3KP89;P09471;P09471-2;P63096;P38405-2; & Guanine nucleotide-binding protein $\mathrm{G}(\mathrm{k})$ subunit alpha; & 3 \\
\hline 58 & P13667 & Protein disulfide-isomerase A4 & 3 \\
\hline 59 & P26038;B7Z4C7;J7M2B1;A7YIJ8;B2R6J2;P15311;Q6NUR7; & Moesin & 3 \\
\hline 60 & P49327 & Fatty acid synthase;[Acyl-carrier-protein] S-acetyltransferase; & 3 \\
\hline 61 & $\mathrm{P} 80723 ; \mathrm{P} 80723-2$ & Brain acid soluble protein 1 & 3 \\
\hline 62 & Q9Y490;Q5TCU6;Q9Y4G6;G1UI21;H0YMT1 & Talin-1 & 3 \\
\hline 63 & Q92945;B4DV73;M0R0I5 & Far upstream element-binding protein 2 & 3 \\
\hline 64 & A1KYQ7;Q99613;B4E1D5;H3BRV0;B4DVQ5; & Eukaryotic translation initiation factor 3 subunit $\mathrm{C}$ & 2 \\
\hline 65 & P46821;A2BDK6;Q5H9P1 & Microtubule-associated protein 1B;MAP1 light chain LC1 & 2 \\
\hline 66 & P55060;P55060-3;A3RLL6;F8W904; & Exportin-2 & 2 \\
\hline 67 & A6NG51;Q13813-2;Q13813;Q13813-3; & Spectrin alpha chain, brain & 2 \\
\hline 68 & Q5JWF2;Q5JWF2-2;A6NI00;P63092;P63092-2; & Guanine nucleotide-binding protein G(s) subunit alpha isoforms XLas; & 2 \\
\hline 69 & A8K2H4;P07858;B4DL49;B3KUJ8;B4DMY4; & Cathepsin B;Cathepsin B light chain;Cathepsin B heavy chain & 2 \\
\hline 70 & A8K2X8;P48643;Q9BU08;E9PCA1;B4DXI1; & T-complex protein 1 subunit epsilon & 2 \\
\hline 71 & Q59EM9;Q66K58;L8B4J3;L8B4M0;L8B4Z6;P0CG48; & Polyubiquitin-C;Ubiquitin;Polyubiquitin-B;Ubiquitin; & 2 \\
\hline 72 & Q14240-2;Q14240;A8K7F6;P60842;E7EQG2;A8K088;Q59F68; & Eukaryotic initiation factor 4A-II;Eukaryotic initiation factor 4A-I & 2 \\
\hline 73 & B7Z525;Q5SZ07;B2RDE8;P51858;P51858-2;B7Z958;A8K8G0 & Hepatoma-derived growth factor & 2 \\
\hline 74 & P08670;Q53HU8;B0YJC4;B3KRK8;A5Z217; & Vimentin;Desmin & 2 \\
\hline 75 & B2R4F3;P52566;F5H3P3;F5H6Q0;F5H2R5;H0YGX7 & Rho GDP-dissociation inhibitor 2 & 2 \\
\hline 76 & B2R4P2;Q06830;Q5IST6;P32119;B4DF70 & Peroxiredoxin-1;Peroxiredoxin-2 & 2 \\
\hline 77 & B4DI54;B2RCQ9;P34931;Q53FA3; & Heat shock $70 \mathrm{kDa}$ protein 1-like; Heat shock $70 \mathrm{kDa}$ protein 1A/1B & 2 \\
\hline 78 & B2RDE1;P06753-2;Q5VU58;Q5VU66;P06753-3;Q5VU72; & Tropomyosin alpha-3 chain;Tropomyosin alpha-1 chain; & 2 \\
\hline 79 & E7EMB3;H0Y7A7;E7ETZ0;B2RDW0;B4DJ51; & Calmodulin & 2 \\
\hline
\end{tabular}




\begin{tabular}{|c|c|c|c|}
\hline 80 & Q15084-2;B3KY95;B5MCQ5;B7Z4M8; & Protein disulfide-isomerase A6 & 2 \\
\hline 81 & P21980;B4DTN7;F5H6P0;B4DIT7;P21980-2;Q6DKH2 & Protein-glutamine gamma-glutamyltransferase 2 & 2 \\
\hline 82 & E9PN11;P08134;P61586;Q5JR08;B4DKN9;Q5JR05; & Rho-related GTP-binding protein RhoC;Transforming protein RhoA & 2 \\
\hline 83 & P07237;B4DNL5;H7BZ94;B4DUA5; & Protein disulfide-isomerase & 2 \\
\hline 84 & Q14103;Q14103-2;Q14103-3;B4DTC3; & Heterogeneous nuclear ribonucleoprotein D0; & 2 \\
\hline 85 & E9KL35;P63244;D6R9L0;D6R9Z1;D6RHH4;B4DVD2; & Guanine nucleotide-binding protein subunit beta-2-like 1 & 2 \\
\hline 86 & P61604;B8ZZL8;Q9UNM1;B8ZZ54 & $10 \mathrm{kDa}$ heat shock protein, mitochondrial & 2 \\
\hline 87 & P62879;Q6FHM2;E7EP32;C9JXA5; & Guanine nucleotide-binding protein $\mathrm{G}(\mathrm{I}) / \mathrm{G}(\mathrm{S}) / \mathrm{G}(\mathrm{T})$ subunit beta-2; & 2 \\
\hline 88 & J3KN41;P23229;P23229-6;P23229-9; & Integrin alpha-6;Integrin alpha-6 heavy chain;Integrin alpha-6 light chain & 2 \\
\hline 89 & P14868;D3DP78;Q68CR9;Q53T60;H7BZ35 & Aspartate--tRNA ligase, cytoplasmic & 2 \\
\hline 90 & O00159;O00159-3;B7Z3E5; & Unconventional myosin-Ic & 2 \\
\hline 91 & Q59ER5;O75083;Q53GN4;Q53H17; & WD repeat-containing protein 1 & 2 \\
\hline 92 & Q32Q12;P22392-2;J3KPD9;P15531-2; & Nucleoside diphosphate kinase;Nucleoside diphosphate kinase A; & 2 \\
\hline 93 & O00299;Q53FB0;Q5SRT3 & Chloride intracellular channel protein 1 & 2 \\
\hline 94 & P00441;H7BYH4;A1YYW4 & Superoxide dismutase $[\mathrm{Cu}-\mathrm{Zn}]$ & 2 \\
\hline 95 & P05387;P05386;Q6FG99;Q6ICQ4;H0YDD8;P05386-2 & $60 \mathrm{~S}$ acidic ribosomal protein $\mathrm{P} 2 ; 60 \mathrm{~S}$ acidic ribosomal protein $\mathrm{P} 1$ & 2 \\
\hline 96 & P07195;Q5U077;A8MW50;C9J7H8;F5H793 & L-lactate dehydrogenase B chain;L-lactate dehydrogenase & 2 \\
\hline 97 & P16035;B4DFW2 & Metalloproteinase inhibitor 2 & 2 \\
\hline 98 & P30041 & Peroxiredoxin-6 & 2 \\
\hline 99 & P55072;Q96IF9;Q0IIN5;Q9NTC4;Q9HAP1 & Transitional endoplasmic reticulum ATPase & 2 \\
\hline 100 & P62306 & Small nuclear ribonucleoprotein $\mathrm{F}$ & 2 \\
\hline 101 & Q00610;Q00610-2;J3KS13;K7EJJ5;J3KRF5 & Clathrin heavy chain 1 & 2 \\
\hline 102 & Q04917 & 14-3-3 protein eta & 2 \\
\hline 103 & Q13442 & $28 \mathrm{kDa}$ heat- and acid-stable phosphoprotein & 2 \\
\hline 104 & Q16270;Q16270-2 & Insulin-like growth factor-binding protein 7 & 2 \\
\hline 105 & Q9H1E3;Q9H1E3-2;Q6IA16 & Nuclear ubiquitous casein and cyclin-dependent kinase substrate 1 & 2 \\
\hline 106 & Q9H3N1;B4DZX7;G3V448 & Thioredoxin-related transmembrane protein 1 & 2 \\
\hline 107 & Q9JFW9;Q9JFX0 & & 2 \\
\hline
\end{tabular}




\begin{tabular}{|c|c|}
\hline 108 & H0Y449;P67809;Q2VIK8;A0JLU4 \\
\hline 109 & P20020;P20020-4;P20020-3;P20020-6; \\
\hline 110 & P23634;P23634-8;P23634-6;Q68DH9;P23634-7;A1X4Q1 \\
\hline 111 & O75942;Q6SES1;A1YVW6;B2R5Q9;P04156;P61768; \\
\hline 112 & P16949-2;B5BU83;P16949;Q96CE4;Q59G27;Q5ISP9;A2A2D0 \\
\hline 113 & A2I3M9 \\
\hline 114 & A3KLL5;P05026;Q6LEU2;P05026-2;A6NGH2;B7Z9S8;Q58I20 \\
\hline 115 & A4D0R1;A8K865;Q16563;A4D0R2;Q16563-2;C9JYN0 \\
\hline 116 & Q16181;A8K3D0;E7EPK1;E7ES33;Q16181-2;A4GYY8;Q3LIE9; \\
\hline 117 & A6NE09;P08865;Q96RS2;C9J9K3 \\
\hline 118 & A7MAP1;Q59EA2;A7MAP0;B3KN06; \\
\hline 119 & Q07955-2;J3KTL2;A8K1L8;Q07955;Q59FA2;Q07955-3 \\
\hline 120 & A8K2Y2;B2R5N2;P41091;Q2VIR3;Q53HK3 \\
\hline 121 & B4E284;F6S8M0;A8K6V6;P15586; \\
\hline 122 & A8K7Q1;Q02818;Q53GX6;B4DZX0;Q96BA4;B3KUR6 \\
\hline 123 & A8K9U9;P36406;P36406-2;P36406-3 \\
\hline 124 & O14786;Q68DN3;A8K9V7;E9PEP6;Q6X907; \\
\hline 125 & A8KAH7;P13861;Q9BUB1 \\
\hline 126 & A8KAH9;P62834;Q5U0C3 \\
\hline 127 & A8KAQ5;P08621;P08621-2;P08621-3 \\
\hline 128 & A8MU27;B4DUW4;A8MUA9;P55854; \\
\hline 129 & P09211;A8MX94;Q5D6A5 \\
\hline 130 & B4DNE1;P35613;P35613-2;Q54A51; \\
\hline 131 & Q59E85;Q03135;Q2TNI1;A9XTE5; \\
\hline 132 & O15511-2;O15511;B1ALC0;Q6IPM3 \\
\hline 133 & B2MEF9 \\
\hline 134 & B2R4R0;P62805;Q0VAS5;Q6B823 \\
\hline 135 & G3V3D1;B4DV10;E7EMS2;G3V3E8;H0YIZ1; \\
\hline
\end{tabular}

Nuclease-sensitive element-binding protein 1

Plasma membrane calcium-transporting ATPase 1

Plasma membrane calcium-transporting ATPase 4

Major prion protein

Stathmin

Sodium/potassium-transporting ATPase subunit beta-1

Synaptophysin-like protein 1

\section{Septin-7}

40S ribosomal protein SA

Coronin-1C

Serine/arginine-rich splicing factor 1

Eukaryotic translation initiation factor 2 subunit 3;

$\mathrm{N}$-acetylglucosamine-6-sulfatase

Nucleobindin-1

E3 ubiquitin-protein ligase TRIM23

Neuropilin-1

cAMP-dependent protein kinase type II-alpha regulatory subunit

Ras-related protein Rap-1A

U1 small nuclear ribonucleoprotein $70 \mathrm{kDa}$

Small ubiquitin-related modifier 3;

Glutathione S-transferase P

Basigin

Caveolin;Caveolin-1;Caveolin-3

Actin-related protein $2 / 3$ complex subunit 5

Histone $\mathrm{H} 4$

Epididymal secretory protein E1

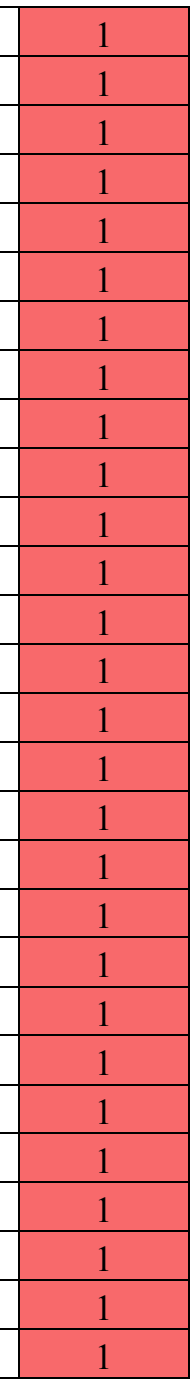




\begin{tabular}{|c|c|c|c|}
\hline 136 & B2R5M8;O75874;Q567U4;Q6FHQ6;Q6FIA4;Q0QER2 & Isocitrate dehydrogenase [NADP]; & 1 \\
\hline 137 & I6TRR8;Q59FF0;Q7KZF4;B3KU67;B4E299;B2R5U1 & Staphylococcal nuclease domain-containing protein 1 & 1 \\
\hline 138 & B2R6S2;P20645;Q53GY9;Q6I9U3;Q96AH2;H0YF90 & Cation-dependent mannose-6-phosphate receptor & 1 \\
\hline 139 & B2R6X5;B3KSM6;P17066;Q53FC7;P48741 & Heat shock $70 \mathrm{kDa}$ protein 6 ;Putative heat shock $70 \mathrm{kDa}$ protein 7 & 1 \\
\hline 140 & B4DDY9;O75830;P30740;P50453; & Serpin I2;Leukocyte elastase inhibitor;Serpin B9;Serpin B8 & 1 \\
\hline 141 & B2R9S4;P40121;P40121-2;B4DU58;E7ENU9 & Macrophage-capping protein & 1 \\
\hline 142 & B2R9U2;Q02790 & Peptidyl-prolyl cis-trans isomerase FKBP4; & 1 \\
\hline 143 & B2RAK1;Q9UIQ6;Q9UIQ6-2;Q9UIQ6-3 & Leucyl-cystinyl aminopeptidase; & 1 \\
\hline 144 & E9PRY8;B2RAR6;D3DWK1;P29692-2;Q9H7G6;Q71RH4; & Elongation factor 1-delta & 1 \\
\hline 145 & B2RBR9;Q14974;B7Z752;B7ZAV6 & Importin subunit beta- 1 & 1 \\
\hline 146 & B2RDI5;P07384;B4DWH5 & Calpain-1 catalytic subunit & 1 \\
\hline 147 & Q12797;B4E2K4;F5H667;B8Y0L3; & Aspartyl/asparaginyl beta-hydroxylase & 1 \\
\hline 148 & P10809;B3GQS7;B7Z597;B7Z5E7; & $60 \mathrm{kDa}$ heat shock protein, mitochondrial & 1 \\
\hline 149 & B3KMQ6;Q9NZT2;Q05BV5;Q9NZT2-2;Q6PK21 & Opioid growth factor receptor & 1 \\
\hline 150 & O00154;B3KQ12;O00154-5;O00154-4;O00154-6;B4DUX0 & Cytosolic acyl coenzyme A thioester hydrolase & 1 \\
\hline 151 & Q6NZI2;B4DNU9;B4DPZ5;B3KRY5;Q6NZI2-2;Q6NZI2-3 & Polymerase I and transcript release factor & 1 \\
\hline 152 & B3KT93;P11940;Q3ZCS4;Q5VX58;Q9H361;Q2VIP3;B4DQX0 & Polyadenylate-binding protein 1;Polyadenylate-binding protein 3 & 1 \\
\hline 153 & B3KUY2;Q15185;B4DP11;B4DHP2;B4DDC6 & Prostaglandin E synthase 3 & 1 \\
\hline 154 & Q59GX2;P11166;Q0P512;B4DKW1;B3KVN0 & Solute carrier family 2 , facilitated glucose transporter member 1 & 1 \\
\hline 155 & P18206;P18206-2;B3KXA2;B4E3Q9;Q5JQ13 & Vinculin & 1 \\
\hline 156 & Q6LES2;P09525;B4DE02;B4DDZ4;Q6P452;B4DDF9;Q59FK3 & Annexin;Annexin A4 & 1 \\
\hline 157 & Q14764;B4DDR2;B4DXN0;B4DP93 & Major vault protein & 1 \\
\hline 158 & P14923;F5GWP8;B4DE59;C9JKY1;C9JK18;C9J826;C9JTX4 & Junction plakoglobin & 1 \\
\hline 159 & B4DE76;P43487;Q53EY3;B7Z6U1;C9JDM3;C9JJ34 & Ran-specific GTPase-activating protein & 1 \\
\hline 160 & Q15700-2;Q12959-2;Q12959-7;Q59FY1;Q15700-4; & Disks large homolog 1;Disks large homolog 2;Disks large homolog 3 & 1 \\
\hline 161 & P35659;B4DNW3;B4DFG0;P35659-2;D6R9L5 & Protein DEK & 1 \\
\hline 162 & Q59GY2;P36578;Q53G74;H3BM89;B4DMJ2;B4DFI6 & 60S ribosomal protein L4 & 1 \\
\hline 163 & P02545;Q5I6Y4;Q5I6Y6;P02545-3;Q6UYC3; & Prelamin-A/C;Lamin-A/C & 1 \\
\hline
\end{tabular}




\begin{tabular}{|c|c|c|c|}
\hline 164 & B4DH02;P34932;Q59GF8;B4DUS3; & Heat shock $70 \mathrm{kDa}$ protein 4 & 1 \\
\hline 165 & Q8WUM4-2;Q4W4Y1;Q8WUM4;B4DHD2;B7Z5C1 & Programmed cell death 6-interacting protein & 1 \\
\hline 166 & P61160-2;P61160;B4DHK9;Q8IY98;B4DWQ5;F5H6T1 & Actin-related protein 2 & 1 \\
\hline 167 & P61086;P61086-3;B4DIZ2;D6RDM7 & Ubiquitin-conjugating enzyme E2 K & 1 \\
\hline 168 & P20339;B4DJA5 & Ras-related protein Rab-5A & 1 \\
\hline 169 & P00338-3;P00338;B4DJI1;F5H308; & L-lactate dehydrogenase A chain;L-lactate dehydrogenase & 1 \\
\hline 170 & Q13610;Q53FW9;Q9BV37;B4DJV5; & Periodic tryptophan protein 1 homolog & 1 \\
\hline 171 & J3KQ32;Q9NTK5;Q9NTK5-3;B4DK14;Q53SW9;C9JTK6 & Obg-like ATPase 1 & 1 \\
\hline 172 & P04843;Q53EP4;Q6IBR0;B4DL99;Q96HX3;F8WF32 & Dolichyl-diphosphooligosaccharide--protein glycosyltransferase subunit 1 & 1 \\
\hline 173 & P57721;P57721-4;Q15366-2;Q15366;Q15366-3;E9PFP8; & Poly(rC)-binding protein 3;Poly(rC)-binding protein 2; & 1 \\
\hline 174 & B4DMW5 & & 1 \\
\hline 175 & P51149;B4DPH9;C9J8S3;C9J592; & Ras-related protein Rab-7a & 1 \\
\hline 176 & I1E4Y6;Q6Y7W6-3;Q6Y7W6;B9EG55; & PERQ amino acid-rich with GYF domain-containing protein 2 & 1 \\
\hline 177 & Q99653;H0YNG9;B4DSB5;F5GX29;H0YKE7;H0YLY7 & Calcium-binding protein $\mathrm{p} 22$ & 1 \\
\hline 178 & P09960;P09960-4;B4DVZ8;P09960-2;P09960-3;Q59ES1 & Leukotriene A-4 hydrolase & 1 \\
\hline 179 & B4DWA0;H7BYM6;P17096-3;P17096; & High mobility group protein HMG-I/HMG-Y & 1 \\
\hline 180 & Q6DD88;B4DXC4;F5H6I7;F5GWF8 & Atlastin-3 & 1 \\
\hline 181 & P29401-2;P29401;Q53EM5;B4E022;E9PFF2;F8W888 & Transketolase & 1 \\
\hline 182 & O43143;B4E0S6 & Putative pre-mRNA-splicing factor ATP-dependent RNA helicase DHX15 & 1 \\
\hline 183 & E9PK25;P23528;Q549N0;Q9Y281;E9PP50;G3V1A4;G3V5P4; & Cofilin-1;Cofilin-2 & 1 \\
\hline 184 & P22692;B4E351 & Insulin-like growth factor-binding protein 4 & 1 \\
\hline 185 & B7Z6Z4;B4E368;P14649;F8W1I5;G3V1V0;G8JLA2; & Myosin light chain 6B;Myosin light polypeptide 6 & 1 \\
\hline 186 & P16144;P16144-3;B7ZLD5;B7ZLD8;P16144-2; & Integrin beta-4;Integrin beta & 1 \\
\hline 187 & P20340;P20340-2;Q6FGX3;Q9NRW1;H0YGL6; & Ras-related protein Rab-6A;Ras-related protein Rab-6B & 1 \\
\hline 188 & B7Z464 & & 1 \\
\hline 189 & P02452;D3DTX7;B7Z4S2 & Collagen alpha-1(I) chain & 1 \\
\hline 190 & P17174;B7Z7E9 & Aspartate aminotransferase, cytoplasmic;Aspartate aminotransferase & 1 \\
\hline 191 & B7Z809;F5H2F4;G3V2B8;P11586;G3V3L6 & C-1-tetrahydrofolate synthase, cytoplasmic; & 1 \\
\hline
\end{tabular}




\begin{tabular}{|c|c|c|c|}
\hline 192 & Q9Y639;Q9Y639-1;B7Z960;F5GYM7;H3BU51 & Neuroplastin & 1 \\
\hline 193 & B7ZKQ8;F5GWY5;O00592;F5H7A2; & Podocalyxin & 1 \\
\hline 194 & P40925-3;P40925;P40925-2;B9A041;B8ZZ51 & Malate dehydrogenase, cytoplasmic & 1 \\
\hline 195 & H7C2N1;B8ZZW7;B8ZZA1;P06454;P06454-2;Q15200; & Prothymosin alpha;Thymosin alpha-1 & 1 \\
\hline 196 & B9A3K3 & & 1 \\
\hline 197 & P08833;Q6PEY6;C1K3N3;C9JXF9;C9J6H2 & Insulin-like growth factor-binding protein 1 & 1 \\
\hline 198 & C5HAX7 & & 1 \\
\hline 199 & C8C593 & & 1 \\
\hline 200 & C8C779 & & 1 \\
\hline 201 & I3L504;P63241-2;P63241;Q6IS14; & Eukaryotic translation initiation factor 5A-1; & 1 \\
\hline 202 & O15144;Q53R19;G5E9J0;C9JTV5;G5E9S7 & Actin-related protein $2 / 3$ complex subunit 2 & 1 \\
\hline 203 & Q59FI9;P30050;D3DS95 & 60S ribosomal protein $\mathrm{L} 12$ & 1 \\
\hline 204 & D3DV26;P60903;Q6FGE5 & Protein S100-A10 & 1 \\
\hline 205 & Q8N3E9;D3DX63 & 1-phosphatidylinositol 4,5-bisphosphate phosphodiesterase delta-3 & 1 \\
\hline 206 & D3WYX8 & & 1 \\
\hline 207 & E2DH85;G1EPS1 & & 1 \\
\hline 208 & E2DIA3 & & 1 \\
\hline 209 & E5RJD8;O75347;Q6FGD7;E5RIW3 & Tubulin-specific chaperone A & 1 \\
\hline 210 & O15347;E7EQU1;E7ES08;E9PES6 & High mobility group protein B3 & 1 \\
\hline 211 & E9KB66 & & 1 \\
\hline 212 & P62917;E9PKU4;E9PIZ3;E9PKZ0;E9PP36 & 60S ribosomal protein L8 & 1 \\
\hline 213 & J3KN86;P23396;Q53G83;E9PL09;H0YEU2; & 40S ribosomal protein $\mathrm{S} 3$ & 1 \\
\hline 214 & P80303;P80303-2;J3KQU0;Q2L696;E9PKG6;H0YEG8 & Nucleobindin-2 & 1 \\
\hline 215 & E9PKH6 & & 1 \\
\hline 216 & E9PR17;P13987;Q6FHM9;E9PNW4;H0YET2 & CD59 glycoprotein & 1 \\
\hline 217 & J3QK90;Q9UNZ2-5;Q53FE8;Q9UNZ2;Q9UNZ2-4;F2Z2K0 & NSFL1 cofactor $\mathrm{p} 47$ & 1 \\
\hline 218 & F6JR01;F6JR32 & & 1 \\
\hline 219 & Q9UQ80;F8VTY8 & Proliferation-associated protein $2 \mathrm{G} 4$ & 1 \\
\hline
\end{tabular}




\begin{tabular}{|c|c|c|c|}
\hline 220 & Q9NQC3;Q9NQC3-5;Q9NQC3-2;F8W914;Q6IPN0;Q53R94 & Reticulon-4 & 1 \\
\hline 221 & P59998-2;P59998-3;F8WCF6;P59998; & Actin-related protein $2 / 3$ complex subunit 4 & 1 \\
\hline 222 & G0XTR1 & & 1 \\
\hline 223 & Q969J3;G3V1P3 & Loss of heterozygosity 12 chromosomal region 1 protein & 1 \\
\hline 224 & P27695;Q5TZP7;G3V3M6;G3V5Q1; & DNA-(apurinic or apyrimidinic site) lyase; & 1 \\
\hline 225 & P25788;P25788-2;G3V4X5;H0YJ03 & Proteasome subunit alpha type- 3 & 1 \\
\hline 226 & Q96IZ0;H0YHP5 & PRKC apoptosis WT1 regulator protein & 1 \\
\hline 227 & P28074;P28074-2;H0YJM8 & Proteasome subunit beta type- 5 & 1 \\
\hline 228 & Q15046-2;Q15046;H3BVA8;H3BPV7;J3KRL2 & Lysine--tRNA ligase & 1 \\
\hline 229 & H7C 133 & & 1 \\
\hline 230 & $\mathrm{P} 07339 ; \mathrm{H} 7 \mathrm{C} 469 ; \mathrm{H} 7 \mathrm{C} 1 \mathrm{~V} 0$ & Cathepsin D;Cathepsin D light chain;Cathepsin D heavy chain & 1 \\
\hline 231 & O95858;H7C285 & Tetraspanin-15 & 1 \\
\hline 232 & P68402;J3KNE3 & Platelet-activating factor acetylhydrolase IB subunit beta & 1 \\
\hline 233 & J3QQX2;P52565;J3KTF8;J3KRE2 & Rho GDP-dissociation inhibitor 1 & 1 \\
\hline 234 & J3QRS3;O14950;P19105;Q53HL1;Q53X45 & Myosin regulatory light chain 12B;Myosin regulatory light chain $12 \mathrm{~A}$ & 1 \\
\hline 235 & J9JID7;Q03252 & Lamin-B2 & 1 \\
\hline 236 & Q8IYT4;Q8IYT4-2;K7EIJ8;K7EM02 & Katanin p60 ATPase-containing subunit A-like 2 & 1 \\
\hline 237 & P35268;Q7Z4W8;K7ERI7 & 60S ribosomal protein $\mathrm{L} 22$ & 1 \\
\hline 238 & K7WHW7;Q3I103;Q5SG66 & & 1 \\
\hline 239 & L0R6I3 & & 1 \\
\hline 240 & O95336;M0R261 & 6-phosphogluconolactonase & 1 \\
\hline 241 & O00468;O00468-7;O00468-4; & Agrin & 1 \\
\hline 242 & O43818 & U3 small nucleolar RNA-interacting protein 2 & 1 \\
\hline 243 & P09382 & Galectin-1 & 1 \\
\hline 244 & $\mathrm{P} 09497 ; \mathrm{P} 09497-2$ & Clathrin light chain B & 1 \\
\hline 245 & P0C5V0;P0C5V1;P0C5V2 & & 1 \\
\hline 246 & P10301 & Ras-related protein R-Ras & 1 \\
\hline 247 & P11717;Q59EZ3 & Cation-independent mannose-6-phosphate receptor & 1 \\
\hline
\end{tabular}




\begin{tabular}{|l|l|}
\hline 248 & P13639;Q6PK56;Q8TA90 \\
\hline 249 & P26447 \\
\hline 250 & P31949 \\
\hline 251 & P41250 \\
\hline 252 & P42677;Q5T4L4 \\
\hline 253 & P54577 \\
\hline 254 & P61106 \\
\hline 255 & P62263 \\
\hline 257 & P62424;Q5T8U3;Q5T8U2;Q9BY74 \\
\hline 258 & Q16186 \\
\hline 259 & Q59GB4;Q16555;Q53ET2;Q16555-2;Q8NAN9 \\
\hline 260 & Q32WN1;Q9NS25;Q32WJ6 \\
\hline 261 & Q53GD1;Q69YP5;Q9UBI6 \\
\hline 262 & Q575U9 \\
\hline 263 & Q5U000;Q9UBR2 \\
\hline 264 & Q5U7I5 \\
\hline 265 & Q69514 \\
\hline 266 & Q70QR1 \\
\hline 267 & Q96EK5 \\
\hline 268 & Q96F88;Q99575 \\
\hline 269 & Q9C004;Q9C004-2 \\
\hline 270 & Q9DHR2 \\
\hline 271 & Q9HCK1 \\
\hline 272 & Q9J723 \\
\hline 273 & Q9Y5B9 \\
\hline 274 & Q9Y5K6 \\
\hline
\end{tabular}

Elongation factor 2

Protein S100-A4

Protein S100-A11

Glycine--tRNA ligase

40S ribosomal protein S27

Tyrosine--tRNA ligase, cytoplasmic

Ras-related protein Rab-14

40S ribosomal protein $\mathrm{S} 14$

$60 \mathrm{~S}$ ribosomal protein $\mathrm{L} 7 \mathrm{a}$

Proteolipid protein 2

Proteasomal ubiquitin receptor ADRM1

Dihydropyrimidinase-related protein 2

Sperm protein associated with the nucleus on the $\mathrm{X}$ chromosome B/F

Guanine nucleotide-binding protein subunit gamma;

Cathepsin Z

KIF1-binding protein

Ribonucleases P/MRP protein subunit POP1

Protein sprouty homolog 4

DBF4-type zinc finger-containing protein 2

FACT complex subunit SPT16

CD2-associated protein

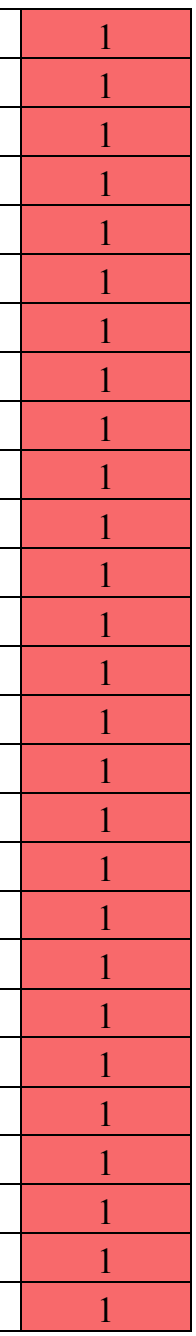

